\title{
Endocrine Disruptors in Water and Their Effects on the Reproductive System
}

\author{
Andressa Gonsioroski, Vasiliki E. Mourikes and Jodi A. Flaws * \\ Department of Comparative Biosciences, University of Illinois at Urbana-Champaign, Urbana, IL 61802, USA; \\ avg5@illinois.edu (A.G.); mourike2@illinois.edu (V.E.M.) \\ * Correspondence: jflaws@illinois.edu
}

Received: 3 February 2020; Accepted: 6 March 2020; Published: 12 March 2020

\begin{abstract}
Anthropogenic contaminants in water can impose risks to reproductive health. Most of these compounds are known to be endocrine disrupting chemicals (EDCs). EDCs can impact the endocrine system and subsequently impair the development and fertility of non-human animals and humans. The source of chemical contamination in water is diverse, originating from byproducts formed during water disinfection processes, release from industry and livestock activity, or therapeutic drugs released into sewage. This review discusses the occurrence of EDCs in water such as disinfection byproducts, fluorinated compounds, bisphenol A, phthalates, pesticides, and estrogens, and it outlines their adverse reproductive effects in non-human animals and humans.
\end{abstract}

Keywords: endocrine disruptors; water; reproduction

\section{Introduction}

Water safety and quality are fundamental to human development and well-being. Besides the pathogenic risk of microbes, several chemical contaminants present in water due to anthropogenic activities can impose risks to human and non-human animal health [1,2]. According to the United States Environmental Protection Agency (USEPA), the definition of contaminant is any physical, chemical, biological, or radiological substance or matter in water. Chemical contaminants are elements or compounds that can be naturally occurring or human-made [3]. The sources of chemical contamination in water are diverse. Chemicals can be present in water through the disinfection processes, chemical release in source water due to industry and livestock activity, and distribution from system components. Non-human animals and humans can be exposed to these compounds by ingesting, inhaling, or dermal contact with contaminated water. Some of the major chemicals that are known as water contaminants are endocrine disrupting chemicals such as disinfection byproducts, fluorinated substances, bisphenols, phthalates, pesticides, and natural and synthetic estrogens. Exposure to these compounds is associated with adverse health and reproductive outcomes in non-human animals and humans; thus, the presence of these chemicals in water has become a public health concern [4-8].

Studies have shown that the contaminants present in water can impair development, fertility, and reproductive function in non-human mammals, humans, and aquatic wild life. For instance, exposure to water disinfection byproducts in drinking water can cause cardiac anomalies in developing rat and porcine embryos [9,10]. Further, exposures to bisphenol A (BPA) and phthalates are known to reduce fertility in mammals by prematurely activating primordial follicles and altering levels of sex-steroid hormones [11-15]. Pesticides have been detected in drinking water sources, and some of these compounds are known reproductive toxicants. For example, exposure to some pesticides is associated with low sperm count and adverse pregnancy outcomes in non-human animals and humans [16-18]. Fluorinated substances also can be found in drinking water. Studies have reported that exposure to perfluorooctanoic acid (PFOA) and perfluorooctanesulfonic acid (PFOS) was responsible for 
impairing sperm viability and fecundability in non-human mammals and humans [19-22]. Moreover, water contaminated with synthetic estrogens can cause adverse pregnancy outcomes in non-human animals [23-25]. Collectively, these previous studies have shown that chemical contaminants in surface and drinking water worldwide can negatively influence the fertility and reproductive capacity of non-human animals and humans.

This review will discuss the occurrence of chemicals in water and their adverse reproductive effects in non-human mammals, humans, and aquatic life. Specifically, this review will focus on the following categories of chemicals found in water: disinfection byproducts, fluorinated compounds, BPA, phthalates, pesticides, and estrogens.

\section{Water Disinfection Byproducts}

The disinfection of drinking water was one of the most important public health achievements in the last century. The treatment of water with disinfectants such as chlorine substantially reduced the incidence of water-borne diseases, and it contributed to increases in life expectancy [26]. However, the reaction between disinfection agents and organic or inorganic matter in source water can form compounds called water disinfection byproducts (DBPs) [27]. The presence of DBPs in drinking water has become a human health concern because epidemiological studies have demonstrated associations between DBP exposure and an increased risk of cancer development and adverse reproductive outcomes [28-32].

\subsection{Sources of Exposure to DBPs}

Several factors can influence the formation of DBPs in drinking water. The presence of organic matter in source water plays a critical role in the formation of these compounds. Organic matter in water mostly consists of molecules such as fulvic, humic, carboxylic, and free amino acids, which are the primary precursors for formation of DBPs [33]. The chemical composition of source water is also an important factor regarding the formation of DBPs. For instance, in areas where the soil and source water are rich in bromine or iodide, the prevalence of brominated or iodinated DBPs tends to be higher than in areas lower in bromine or iodine [34,35]. Generally, increasing temperatures elevate the formation rates of DBPs. In addition, source water with low $\mathrm{pH}$ has been associated with high levels of DBPs because the most reactive form of chlorine, hypoclorous acid, is present in high concentrations in water sources with $\mathrm{pHs}$ lower than 7.5. Other important elements for DBP formation are the type and concentration of the disinfectant agent used to treat the water. For example, chlorine is known to have the highest potential to form DBPs, especially haloacetic acids, compared to chloramine, chlorine dioxide, or ozone [36].

A significant number of people are exposed to DBPs because of the widespread use of disinfectant agents to treat the water. The most common route of exposure is ingesting treated water, but other potential sources are consumption of food and beverages that were prepared with treated water [27]. Inhalation and dermal absorption also can occur by using showers, bath tubs, swimming pools, or steam rooms [27,36]. To date, more than 700 DBPs have been identified in drinking water [37]; however, only 11 of these compounds are regulated by the USEPA.

The two major classes of DBPs are called trihalomethanes or total trihalomethanes (THMs or TTHMs) and haloacetic acids (HAAs). THMs were the first DBPs identified, and they are the most prevalent in drinking water [37]. Chloroform, bromoform, bromodichloromethane, and chlorodibromomethane are the four THMs that are currently regulated by the USEPA at the maximum contaminant level (MCL) of $0.080 \mathrm{mg} / \mathrm{L}$ [38] (Table 1). From 2013 to 2015, the average levels of TTHMs in US drinking water supplies were $0.03 \mathrm{mg} / \mathrm{L}$ [39]. HAAs are the second most prevalent DBPs in drinking water. In 1998, the USEPA first regulated the sum of five HAAs (bromoacetic acid, dibromoacetic acid, chloroacetic acid, dichloroacetic acid, and trichloroacetic acid), creating a group called HAA5. In 2016, the USEPA required monitoring for four additional HAAs, encompassing a group called HAA9. The MCL for HAA5 is $0.060 \mathrm{mg} / \mathrm{L}$ (Table 1), and levels in drinking water have been reported to be at or below this number [40]. 
Table 1. USEPA Drinking Water Regulations for DBPs.

\begin{tabular}{lll}
\hline Disinfection Byproduct & $\mathbf{M C L G}^{\mathbf{1}}(\mathbf{m g} / \mathbf{L})^{\mathbf{4}}$ & $\mathbf{M C L}^{\mathbf{2}}$ or TT $^{\mathbf{3}}(\mathbf{m g} / \mathbf{L})^{\mathbf{4}}$ \\
\hline Bromate & 0 & 0.010 \\
Chlorite & 0.8 & 1.0 \\
Haloacetic acids (HAA5) & $\mathrm{n} / \mathrm{a}$ & 0.060 \\
Dichloroacetic acid & $0 \mathrm{mg} / \mathrm{L}$ & \\
Trichloroacetic acid & $0.02 \mathrm{mg} / \mathrm{L}$ & \\
Monochloroacetic acid & $0.07 \mathrm{mg} / \mathrm{L}$ & \\
Bromoacetic acid & n/a & \\
Dibromoacetic acid & n/a & 0.080 \\
Total Trihalomethanes (TTHMs) & n/a & \\
Bromodichloromethane & $0 \mathrm{mg} / \mathrm{L}$ & \\
Bromoform & $0 \mathrm{mg} / \mathrm{L}$ & \\
Dibromochloromethane & $0.06 \mathrm{mg} / \mathrm{L}$ & \\
Chloroform & $0.07 \mathrm{mg} / \mathrm{L}$ & \\
\hline
\end{tabular}

\footnotetext{
${ }^{1}$ Maximum Contaminant Level Goal (MCLG)-The level of a contaminant in drinking water below which there is no known or expected risk to health. MCLGs allow for a margin of safety and are non-enforceable public health goals. ${ }^{2}$ Maximum Contaminant Level (MCL)-The highest level of a contaminant that is allowed in drinking water. MCLs are set as close to MCLGs as feasible using the best available treatment technology and taking cost into consideration. MCLs are enforceable standards. ${ }^{3}$ Treatment Technique (TT)-A required process intended to reduce the level of a contaminant in drinking water. ${ }^{4}$ Units are in milligrams per liter $(\mathrm{mg} / \mathrm{L})$. Milligrams per liter are equivalent to parts per million (PPM).Source: USEPA, 2010 [38].
}

DBPs have also been identified in swimming pool and spa water [41]. The water from these sources changes with the climate, the number and behavior of the users of pools or spas, activities of the swimmers, body fluids such as sweat and urine, as well as environmental contaminants brought into the pool on the skin (sun protectants, lotions) and clothes (bather load) [37,42]. All these components are suitable for reaction with disinfectant agents used to treat the water and can lead to the formation of DBPs. Daiber et al. reported that the total DBP concentrations are higher in water from pools and spas compared to their respective filling waters, which is likely due to the constant availability of disinfectants and organic matter input from swimmers [43]. Besides posing a risk to swimmers because of dermal absorption of DBPs, swimming pools and spas are a concern for public health because volatile DBPs can be trapped in the pool environment, especially in indoor pools, increasing the possible exposure to DBPs via inhalation [41].

\subsection{Effects of DBPs on the Reproductive System}

\subsubsection{Non-Human Animals}

The toxicological effects of DBPs on developmental and reproductive outcomes have been studied in non-human animals from embryo development to birth. Teixido et al. investigated 10 regulated DBPs (four THMs, five HAAs, and bromate) to assess the developmental toxicity and genotoxicity of these compounds in zebrafish embryos. The authors reported that DBPs caused adverse developmental effects, significant reductions in the tail length (THMs exposure), and increases in malformation rates (tribromoacetic acid, dichloroacetic acid, and bromate exposure) [44]. In a different study, the developmental toxicity of 15 DBPs was assessed using the zebra fish embryo model. The toxicity rank order reported was: acetamides $>$ HAAs $>$ acetonitriles $\sim$ nitrosamines. Furthermore, the study showed that brominated and iodinated DBPs tended to be more toxic than their chlorinated analogues [45]. Wang et al. tested the toxicity of halobenzoquinones, which are an emerging class of DBPs that have been detected in drinking water and swimming pool water [46]. They exposed zebrafish embryos to these compounds and compared the effects of halobenzoquinones to those found in zebrafish embryos exposed to HAAs. They showed that halobenzoquinones induced reactive oxygen species (ROS) generation and inhibited the antioxidative response of cells in developing zebrafish, resulting in death, physical malformations, oxidative DNA damage, and apoptosis. They also determined that the acute 
toxicity and ROS induction of halobenzoquinones was up to 200 times more potent than those induced by HAAs [46] (Table 2).

Besides causing developmental effects in zebrafish embryos, DBPs have been shown to be toxic to mouse, rat, and porcine embryos. In a study using CD-1 mouse embryos, the effects of exposure to different HAAs during a period of $24 \mathrm{~h}$ were assessed. Exposure to HAAs resulted in dysmorphogenesis, alterations in development of the neural tube and optic nerves, and abnormal heart development [47]. Andrews et al. exposed rat embryos to various concentrations of dichloro, dibromo, and bromochloroacetic acid (HAAs) for $48 \mathrm{~h}$ and then assessed dysmorphology. The primary effects of HAAs observed were dysmorphogenesis, heart defects, and to a lesser extent, prosencephalic, visceral arch, and eye defects. The developmental effect scores for embryos exposed to the combination of HAAs were higher when compared to the effect scores for embryos exposed to the single compounds, suggesting that the developmental toxicity of these DBPs was additive [9]. Further, exposure to environmentally relevant concentrations of bromodichloromethane, a type of THM, caused transcriptomic and epigenomic adaptive modifications compatible with the cardiac anomalies in porcine blastocysts [10] (Table 2).

DBPs also have been shown to disrupt ovarian function, spermatogenesis, and fertility outcomes. To evaluate the effects of dibromoacetic acid on ovarian function, Bodensteiner et al. exposed female Dutch-belted rabbits daily to dibromoacetic acid through drinking water (0, 1, 5, or $50 \mathrm{mg}$ DBA/kg body weight) from gestation day 15 throughout life [48]. They observed that dibromoacetic acid reduced the number of primordial follicles and total healthy follicles in prepubertal rabbits. In adult rabbits, dibromoacetic acid decreased the number of primordial follicles compared to the non-exposed rabbits [48]. In mice, iodoacetic acid inhibited antral follicle growth and reduced estradiol production by ovarian follicles in vitro [49]. To determine the mechanisms by which iodoacetic acid caused these alterations, Gonsioroski et al. [50] analyzed the gene expression and sex steroid hormone levels of mouse ovarian follicles in vitro. They showed that iodoacetic acid dysregulated the expression of apoptotic factors, cell cycle regulators, steroidogenic factors, and estrogen receptors, subsequently disrupting cell proliferation and steroidogenesis [50]. Narotsky et al. assessed the combined toxicity of regulated DBPs (TTHMs, HAAs, or TTHMs and HAAs) on the fertility indices of rats [51]. They observed that all three mixtures caused pregnancy loss and that HAAs alone or HAAs plus TTHMs increased resorption rates. In another study, the reproductive effects of an environmentally relevant mixture of DBPs representative of chlorinated drinking water were evaluated in rats in a multigenerational bioassay. The authors did not observe adverse effects of DBP exposure on pup weight, prenatal loss, pregnancy rate, gestation length, puberty onset in males, growth, estrous cycles, and hormone levels. However, the DBPs delayed puberty for F1 females, reduced caput epidydimal sperm counts in F1 adult males, and increased the incidence of thyroid follicular cell hypertrophy in adult females [52]. In male rats, dibromoacetic acid caused histopathologic changes in the testis and epididymis. Specifically, dibromoacetic acid caused the retention of spermatids, fusion of mature spermatids, and presence of atypical residual bodies in the epithelium and lumen of seminiferous tubules. In addition, the exposure caused distorted sperm heads, vacuolation of the Sertoli cell cytoplasm, vesiculation of the acrosomes of late spermatids, and marked atrophy of the seminiferous tubules [30]. Melnick et al. described similar testicular lesions in mice exposed to dibromoacetic acid. Specifically, lesions were characterized as spermatid retention and large atypical residual bodies in seminiferous tubules, which were suggested to be a result of the impaired degradative function in Sertoli cells [53] (Table 2). 
Table 2. Effects of DBPs on the Reproductive System.

\begin{tabular}{|c|c|c|c|c|c|c|}
\hline Chemical & $\begin{array}{l}\text { Exposure } \\
\text { Window }\end{array}$ & Dose & Model/Study Population & Effects & Conclusions & Reference \\
\hline $\begin{array}{l}\text { Trihalomethanes (THM4), } \\
\text { haloacetic acids(HAA5), bromate }\end{array}$ & $\begin{array}{l}\text { Developmental } \\
\text { exposure }\end{array}$ & $20-100 \mu \mathrm{g} / \mathrm{mL}$ & Zebra fish embryos & $\begin{array}{l}\text { - Adverse developmental } \\
\text { effects, reduced tail length, } \\
\text { increased malformation rates }\end{array}$ & $\begin{array}{l}\text { Weak capacity of the selected } \\
\text { disinfection products to cause } \\
\text { developmental effects at } \\
\text { environmentally relevant } \\
\text { concentrations. }\end{array}$ & [44] \\
\hline $\begin{array}{l}\text { Chloroacetamide, } \\
\text { bromoacetamide, iodoacetamide, } \\
\text { chloroacetic acid, bromoacetic } \\
\text { acid, iodoacetic acid, } \\
\text { chloroacetonitrile, } \\
\text { dichloroacetonitrile, } \\
\text { trichloroacetonitrile, } \\
\text { bromoacetonitrile, } \\
\text { dibromoacetonitrile, } \\
\text { iodoacetonitrile, } \\
\text { n-nitrosodimethylamine, } \\
\text { n-nitrosodiphenylamine, } \\
\text { n-nitrosomorpholine }\end{array}$ & $\begin{array}{l}\text { Developmental } \\
\text { exposure }\end{array}$ & $1-500 \mu \mathrm{M}$ & Zebra fish embryos & $\begin{array}{l}\text { - Yolk sac and pericardial edema } \\
\text { Axis, eye, snout, jaw, somite, } \\
\text { pectoral fin, and caudal } \\
\text { fin malformations } \\
\text { Delayed developmental } \\
\text { progression, reduced } \\
\text { sensitivity to touch }\end{array}$ & $\begin{array}{l}\text { The selected DBPs altered zebra } \\
\text { fish development. }\end{array}$ & [45] \\
\hline $\begin{array}{l}\text { 2,6-dichloro-1,4-benzoquinone, } \\
\text { 2,5-dichloro-1,4-benzoquinone, } \\
\text { 2,5-dibromo-1,4-benzoquinone, } \\
\text { tetrachloro-1,4-benzoquinone, } \\
\text { tetrabromo-1,4-benzoquinone, } \\
\text { dichloroacetic acid, dibromoacetic } \\
\text { acid, iodoacetic acid }\end{array}$ & $\begin{array}{l}\text { Developmental } \\
\text { exposure }\end{array}$ & $0-16 \mu \mathrm{M}$ & Zebra fish embryos & $\begin{array}{l}\text { Increased mortality, reactive } \\
\text { oxygen species, DNA damage, } \\
\text { apoptosis, uninflated swim } \\
\text { bladder, tail injury, pericardial } \\
\text { edema, shortened body length, } \\
\text { shortened yolk sac extension, } \\
\text { developmental delay }\end{array}$ & $\begin{array}{l}\text { Halobenzoquinones are acutely } \\
\text { toxic, causing oxidative damage } \\
\text { and developmental toxicity to } \\
\text { zebrafish larvae. }\end{array}$ & [46] \\
\hline $\begin{array}{l}\text { Trichloroacetic acid, } \\
\text { dichloroacetic acid, chloroacetic } \\
\text { acid, bromoacetic acid, } \\
\text { tribromoacetic acid, tri- } \\
\text { fluoroacetic acid, difluoroacetic } \\
\text { acid, dibromoacetic acid }\end{array}$ & $\begin{array}{l}\text { Developmental } \\
\text { exposure }\end{array}$ & 1 to $17,000 \mu \mathrm{M}$ & CD-1 mouse embryos & $\begin{array}{l}\text { Prosencephalic hypoplasia, } \\
\text { non-closure, impaired optic } \\
\text { development, malpositioned } \\
\text { and/or hypoplastic pharyn- } \\
\text { geal arches, and perturbation } \\
\text { of heart development }\end{array}$ & $\begin{array}{l}\text { The selected haloacetic acids } \\
\text { analyzed are potential } \\
\text { developmental toxicants. }\end{array}$ & [47] \\
\hline
\end{tabular}


Table 2. Cont

\begin{tabular}{|c|c|c|c|c|c|c|}
\hline Chemical & $\begin{array}{l}\text { Exposure } \\
\text { Window }\end{array}$ & Dose & Model/Study Population & Effects & Conclusions & Reference \\
\hline Dibromoacetic acid & $\begin{array}{l}\text { Gestational, } \\
\text { lactational, and } \\
\text { adult exposure }\end{array}$ & $0,1,5$, or $50 \mathrm{mg} / \mathrm{kg}$ & $\begin{array}{l}\text { Female Dutch-belted } \\
\text { rabbits }\end{array}$ & $\begin{array}{l}\text { - Reduction in number of } \\
\text { primordial follicles and total } \\
\text { healthy follicles } \\
\text { - In adult animals, fewer } \\
\text { primordial follicles }\end{array}$ & $\begin{array}{l}\text { Chronic exposure to } \\
\text { dibromoacetic acid diminishes } \\
\text { the ovarian primordial follicle } \\
\text { population. }\end{array}$ & [48] \\
\hline $\begin{array}{l}\text { Chloroacetic acid, bromoacetic } \\
\text { acid, iodoacetic acid }\end{array}$ & $\begin{array}{l}48 \text { and } 96 \mathrm{~h} \\
\text { in vitro } \\
\text { exposure of } \\
\text { ovarian follicles }\end{array}$ & $\begin{array}{l}0.25-1.00 \mathrm{mM} \text { of chloroacetic } \\
\text { acid; } 2-15 \mu \mathrm{M} \text { of } \\
\text { bromoacetic acid or } \\
\text { iodoacetic acid }\end{array}$ & $\begin{array}{l}\text { Ovarian follicles from CD-1 } \\
\text { mice }\end{array}$ & $\begin{array}{l}\text { - Inhibition of antral } \\
\text { follicle growth } \\
\text { - } \quad \text { Reduction of estradiol levels }\end{array}$ & $\begin{array}{l}\text { The selected monoHAAs inhibit } \\
\text { the growth of antral follicles and } \\
\text { reduce estradiol levels compared } \\
\text { to controls in a dose-response } \\
\text { manner. }\end{array}$ & [49] \\
\hline Iodoacetic acid & $\begin{array}{l}96 \mathrm{~h} \text { in vitro } \\
\text { exposure of } \\
\text { ovarian follicles }\end{array}$ & $2-15 \mu \mathrm{M}$ of iodoacetic acid & $\begin{array}{l}\text { Ovarian follicles from CD-1 } \\
\text { mice }\end{array}$ & $\begin{array}{l}\text { Inhibition of antral follicle } \\
\text { growth, reduction of } \\
\text { estradiol levels } \\
\text { Altered expression of genes } \\
\text { related to the cell cycle, } \\
\text { ovarian steroidogenesis, } \\
\text { apoptosis, and } \\
\text { estrogen receptors } \\
\text { - Altered levels of } \\
\text { steroid hormones }\end{array}$ & $\begin{array}{l}\text { Iodoacetic acid exposure inhibits } \\
\text { follicle growth, decreases cell } \\
\text { proliferation, and alters } \\
\text { steroidogenesis in mouse ovarian } \\
\text { follicles in vitro. }\end{array}$ & [50] \\
\hline $\begin{array}{l}\text { Chloroform, } \\
\text { bromodichloromethane, } \\
\text { chlorodibromomethane, } \\
\text { bromoform chloroacetic acid, } \\
\text { dichloroacetic acid, trichloroacetic } \\
\text { acid, bromoacetic acid, } \\
\text { dibromoacetic acid }\end{array}$ & $\begin{array}{l}\text { Gestational } \\
\text { exposure }\end{array}$ & $1-72 \mathrm{mg} / \mathrm{kg}$ body weight & F344 rats & $\begin{array}{l}\text { Increased pregnancy loss, } \\
\text { embryo resorption, eye } \\
\text { malformations } \\
\text { (anophthalmia, microphthalmia) }\end{array}$ & $\begin{array}{l}\text { Haloacetic acids cause pregnancy } \\
\text { loss and contribute to the } \\
\text { potency of the THM-HAA } \\
\text { mixture in causing pregnancy } \\
\text { loss. }\end{array}$ & [51] \\
\hline
\end{tabular}


Table 2. Cont

\begin{tabular}{|c|c|c|c|c|c|c|}
\hline Chemical & $\begin{array}{l}\text { Exposure } \\
\text { Window }\end{array}$ & Dose & Model/Study Population & Effects & Conclusions & Reference \\
\hline $\begin{array}{l}106 \text { DBPs and other chemicals } \\
\text { identified or measured in a } \\
\text { chlorinated concentrate water }\end{array}$ & $\begin{array}{l}\text { Gestational, } \\
\text { lactation, } \\
\text { prepubertal } \\
\text { exposure }\end{array}$ & $\mathrm{N} / \mathrm{A}$ & Sprague-Dawley rats & $\begin{array}{l}\text { - } \quad \text { Delayed puberty for } \\
\text { F1 females } \\
\text { - } \quad \text { Reduced caput epidydimal } \\
\text { sperm counts in F1 adult males } \\
\text { - Increased incidence of thyroid } \\
\text { follicular cell hypertrophy in } \\
\text { adult females }\end{array}$ & $\begin{array}{l}\text { Exposure to DBPs affects puberty, } \\
\text { sperm production, and thyroid } \\
\text { cells. }\end{array}$ & [52] \\
\hline Dibromoacetic acid & Adult exposure & $\begin{array}{l}0,125,250,500,1,000 \text {, and } \\
2,000 \mathrm{mg} / \mathrm{L} \text { in the } 2 \text {-week } \\
\text { and 3-month studies, and } 0, \\
50,500 \text {, and } 1,000 \mathrm{mg} / \mathrm{L} \text { in } \\
\text { the 2-year studies }\end{array}$ & $\begin{array}{l}\mathrm{F} 344 / \mathrm{N} \text { rats and } \mathrm{B} 6 \mathrm{C}_{3} \mathrm{~F}_{1} \\
\text { mice }\end{array}$ & $\begin{array}{l}\text { Delayed spermiation and } \\
\text { atypical residual bodies in } \\
\text { male rats and mice } \\
\text { - Atrophy of the germinal } \\
\text { epithelium in rats }\end{array}$ & $\begin{array}{l}\text { Dibromoacetic acid adversely } \\
\text { affects male reproductive } \\
\text { tissues/processes. }\end{array}$ & [53] \\
\hline $\begin{array}{l}\text { Chloroform, } \\
\text { bromodichloromethane }\end{array}$ & $\begin{array}{l}\text { Gestational } \\
\text { exposure }\end{array}$ & $\begin{array}{l}\text { Levels in the } \\
\text { water-distribution systems: } \\
\text { Chloroform: }<50 \mu \mathrm{g} / \mathrm{L} \text {, } \\
50-74 \mu \mathrm{g} / \mathrm{L}, 75-99 \mu \mathrm{g} / \mathrm{L} \text {, and } \\
100 \mu \mathrm{g} / \mathrm{L} \text {, and } \\
\text { bromodichloromethane: } \\
<5 \mu \mathrm{g} / \mathrm{L}, 5-9 \mu \mathrm{g} / \mathrm{L} \text {, } \\
10-19 \mu \mathrm{g} / \mathrm{L} \text {, and }>20 \mu \mathrm{g} / \mathrm{L}\end{array}$ & $\begin{array}{l}49,842 \text { women who had a } \\
\text { singleton birth in Nova } \\
\text { Scotia, Canada between } \\
1988 \text { and } 1995\end{array}$ & $\begin{array}{ll}\text { - } & \text { Increased risk of neural } \\
\text { tube defects } \\
\text { - } \quad \text { Increased risk of } \\
\text { chromosomal abnormalities }\end{array}$ & $\begin{array}{l}\text { Chloroform and } \\
\text { bromodichloromethane } \\
\text { gestational exposure is } \\
\text { associated with increased risk of } \\
\text { neural tube defects and } \\
\text { chromosomal abnormalities. }\end{array}$ & [54] \\
\hline $\begin{array}{l}\text { Trihalomethanes and haloacetic } \\
\text { acids }\end{array}$ & $\begin{array}{l}\text { Gestational } \\
\text { exposure }\end{array}$ & $\begin{array}{l}\text { Concentrations of } \\
\text { trihalomethanes and } \\
\text { haloacetic acids in the } \\
\text { water-distribution systems } \\
(0.1-49.3 \mu \mathrm{g} / \mathrm{L})\end{array}$ & $\begin{array}{l}\text { Pregnant women aged } 25 \\
\text { to } 34 \text { years. Term newborn } \\
\text { cases with birth weights } \\
<10 \text { th percentile }(\mathrm{n}=571) \\
\text { were compared with } 1925 \\
\text { term controls with birth } \\
\text { weights } \geq 10 \text { th percentile. } \\
\text { Québec City, Canada area }\end{array}$ & $\begin{array}{l}\text { - Increased risk of small for } \\
\text { gestational age }\end{array}$ & $\begin{array}{l}\text { Trihalomethane and haloacetic } \\
\text { acid gestational exposure is } \\
\text { associated with increased risk of } \\
\text { small for gestational age. }\end{array}$ & [55] \\
\hline
\end{tabular}


Table 2. Cont

\begin{tabular}{|c|c|c|c|c|c|c|}
\hline Chemical & $\begin{array}{l}\text { Exposure } \\
\text { Window }\end{array}$ & Dose & Model/Study Population & Effects & Conclusions & Reference \\
\hline $\begin{array}{l}\text { Trihalomethanes and haloacetic } \\
\text { acids }\end{array}$ & $\begin{array}{l}\text { Gestational } \\
\text { exposure }\end{array}$ & $\begin{array}{l}\text { Maternal DBPs exposures } \\
(0.2-45.6 \mu \mathrm{g} / \mathrm{L})\end{array}$ & $\begin{array}{l}\text { Longitudinal multi-ethnic } \\
\text { birth cohort study in } \\
\text { Bradford, England with } \\
\text { pregnant women }\end{array}$ & $\begin{array}{l}\text { - Birth weight reduction of } \\
\text { approximately } 50 \mathrm{~g}\end{array}$ & $\begin{array}{l}\text { Exposure to trihalomethane } \\
\text { during pregnancy is associated } \\
\text { with adverse fetal growth, } \\
\text { including reduced birth weight. }\end{array}$ & [56] \\
\hline $\begin{array}{l}\text { Chloroform, } \\
\text { bromodichloromethane, } \\
\text { dibromochloromethane, } \\
\text { bromoform, trichloroacetic acid, } \\
\text { dichloroacetic acid, } \\
\text { monobromoacetic acid and } \\
\text { summary DBP measures } \\
\text { (trihalomethanes, haloacetic acids, } \\
\text { brominated trihalomethanes, and } \\
\text { DBP9 (sum of trihalomethanes, } \\
\text { haloacetic acids) }\end{array}$ & $\begin{array}{l}\text { Gestational } \\
\text { exposure }\end{array}$ & $\begin{array}{l}\text { Second-trimester } \\
\text { disinfectant byproduct } \\
(\mu \mathrm{g} / \mathrm{L}) \text { exposure levels for } \\
\text { cases and controls, } \\
1998-2004(0-31.9 \mu \mathrm{g} / \mathrm{L})\end{array}$ & $\begin{array}{l}2460 \text { stillbirth cases } \\
1997-2004 \text { in } \\
\text { Massachusetts, US }\end{array}$ & $\begin{array}{l}\text { - Positive associations between } \\
\text { stillbirth and DBP exposure }\end{array}$ & $\begin{array}{l}\text { Trihalomethanes exposure } \\
\text { increases risk of stillbirth. }\end{array}$ & [57] \\
\hline Trihalomethanes & Adult exposure & $\begin{array}{l}\text { Baseline blood } \\
\text { concentrations of } \\
\text { trihalomethanes (mean of } \\
0.58-57.68 \mathrm{ng} / \mathrm{L} \text { ) }\end{array}$ & $\begin{array}{l}401 \text { men in Wuhan, China } \\
\text { between April } 2011 \text { and } \\
\text { May } 2012\end{array}$ & $\begin{array}{l}\text { Moderate levels of } \\
\text { bromodichloromethane were } \\
\text { associated with decreased } \\
\text { sperm count and declined } \\
\text { sperm linearity }\end{array}$ & $\begin{array}{l}\text { Elevated trihalomethane } \\
\text { exposure may lead to decreased } \\
\text { sperm concentration and serum } \\
\text { total testosterone. }\end{array}$ & {$[58]$} \\
\hline Trihalomethanes & Adult exposure & $\begin{array}{l}\text { Baseline blood } \\
\text { concentrations of } \\
\text { trihalomethanes (mean of } \\
0.58-57.68 \mathrm{ng} / \mathrm{L} \text { ) }\end{array}$ & $\begin{array}{l}401 \text { men in Wuhan, China } \\
\text { between April } 2011 \text { and } \\
\text { May } 2012 \text { and }\end{array}$ & $\begin{array}{l}\text { - Genetic polymorphisms of } \\
\text { CYP2E1 and GSTZ1 were } \\
\text { associated with semen quality }\end{array}$ & $\begin{array}{l}\text { A combination of genetic } \\
\text { susceptibility and environmental } \\
\text { exposure to trihalomethanes may } \\
\text { be associated with semen quality } \\
\text { parameters. }\end{array}$ & [59] \\
\hline
\end{tabular}




\subsubsection{Humans}

DBPs have been shown to be associated with adverse reproductive outcomes in women and men. For instance, in a retrospective cohort study conducted in Nova Scotia, Canada, consisting of 49,842 women who had a singleton birth between 1988 and 1995, exposure to chloroform and bromodichloromethane were associated with neural tube defects, cardiovascular defects, cleft defects, as well as chromosomal abnormalities [54]. For neural tube defects, the risk was increased with high exposure to bromodichloromethane but not chloroform. Further, a stronger relation between chloroform and chromosomal abnormalities was observed than between bromodichloromethane and chromosomal abnormalities [54]. In another study, Levallois et al. evaluated the association between maternal exposure to DBPs and the risk of delivering a small for-gestational-age neonate. HAA concentrations above the fourth quartile and THM or HAA concentrations above current water standards increased the risk for small for gestational age neonates [55]. In addition, in a study of 7438 singleton term babies in Bradford, England, TTHM exposure during pregnancy was associated with reduced birth weight [56]. Moreover, in a study of 2460 stillbirth cases from 1997 to 2004 in Massachusetts, chloroform and dichloroacetic acid exposures were associated with stillbirths [57]. In China, exposure to TTHMs was associated with decreased sperm concentration and serum testosterone in men [58]. Further, studies found that a GSTT1 polymorphism modified the association between exposure to bromo-THMs and decreased sperm motility. In addition, cytochrome P450 2E1 (CYP2E1) polymorphisms were associated with the internal blood concentrations of chloroform and TTHM [59] (Table 2).

\subsubsection{Null Studies}

Although some studies show that DBPs are associated with adverse reproductive outcomes, other studies have not found associations. For example, Cummings and Hedge did not observe effects of dibromoacetic acid in drinking water on the number of implantation sites found on gestational day 9 , the number of pups per litter, the number of resorptions, or mean pup weight in rats [60]. Further, Weber et al. did not observe the effects of prenatal dibromoacetic acid exposure on daily sperm production, testicular sperm counts, epididymal sperm reserves, the morphology of seminiferous epithelium, or ovarian follicle counts in mice [61]. Narotsky et al. did not observe effects of a mixture of regulated DBPs on fertility, pregnancy maintenance, prenatal survival, postnatal survival, or birth weights in the parental, F1, and F2 generation of rats [62]. In human studies, no associations were found between exposure to DBPs and time to pregnancy, duration of gestation, small size for gestational age, stillbirths, preterm births, or birth weight [63-68]. Furthermore, some studies show that poor semen quality is not associated with exposure to DBPs in men [69-71].

These inconsistencies in the literature may be due to several factors. In experiments that use non-human animal models, the levels of DBP exposure are not always environmentally relevant, which can lead to discrepant findings. Further, the methods applied to treat non-human animals with DBPs do not always follow the routes of exposure for human and non-human animals (for example gavage versus drinking water). Thus, it is important for future studies to analyze the effects of single DBPs or mixtures of DBPs at environmentally relevant levels using relevant routes of exposure. In human epidemiological studies, differences in the size and genetic variability of the populations and variations in exposure levels makes comparison of results difficult among studies. The incorporation of subject behaviors into exposure evaluation, such as showering and swimming activities or the consumption of bottled or filtered water, could provide a better understanding of individual exposure to DBPs. Finally, few studies have been done on emerging DBPs and the underlying mechanisms of action of DBPs, opening up areas for additional research.

\section{Perfluoroalkyl and Polyfluoroalkyl Substances}

Fluorinated substances are a wide group of organic and inorganic substances that contain at least one fluorine atom. A subset of these substances contains carbon atoms, on which all the hydrogen 
substituents have been replaced by fluorine atoms. These compounds are called perfluoroalkyl and polyfluoroalkyl substances (PFAS) [72]. In perfluoroalkyl substances, all carbons except the last one are attached to fluorines, and the last carbon attaches to the functional group. In polyfluoroalkyl substances, at least one, but not all carbons are attached to fluorines [73]. PFAS are human-made chemicals that have important properties such as hydrophobic and lipophobic nature, and chemical and biological stability. As a result of these properties, PFAS are used in a wide variety of consumer products and are highly persistent in the environment [74]. The presence of these chemicals in the environment is a concern for public health because exposure to PFAS has been associated with an increased incidence of tumors, endocrine disruption, impaired neurodevelopment, and adverse reproductive outcomes in humans and non-human animals [75-84].

\subsection{Sources of Exposure to PFAS}

According to the USEPA, PFAS can be found in food packaged in PFAS-containing materials, processed with equipment that used PFAS, or grown in PFAS-contaminated soil or water. These compounds also can be found in commercial household products including stain- and water-repellent fabrics, nonstick products (pans), polishes, waxes, paints, cleaning products, and fire-fighting foams (a major source of groundwater contamination at airports and military bases where firefighting training occurs). Moreover, PFAS can be found in the workplace, including production facilities or industries that use these compounds. PFAS also can be found in drinking water, which is typically localized and associated with a specific facility (e.g., manufacturer, landfill, wastewater treatment plant, firefighter training facility). PFAS also can be present in living organisms, including fish, non-human mammals, and humans, where these chemicals have the ability to build up and persist over time [85]. Common PFAS are listed in Table 3.

Table 3. Common PFAS.

\begin{tabular}{ll}
\hline Abbreviation & Chemical Name \\
\hline PFOS & Perfluorooctane sulfonic acid \\
PFOA (aka C8) & Perfluorooctanoic acid \\
PFNA & Perfluorononanoic acid \\
PFDA & Perfluorodecanoic acid \\
PFOSA (aka FOSA) & Perfluorooctane sulfonaminde \\
MeFOSAA (aka Me-PFOSA-AcOH) & 2-(N-Methyl-perfluorooctane sulfonamido) acetic acid \\
Et-FOSAA (aka Et-PFOSA-AcOH) & 2-(N-Ethyl-perfluorooctane sulfonamido) acetic acid \\
PFHxS & Perfluorohexane sulfonic acid \\
\hline
\end{tabular}

Source: ATSDR, 2017 [73].

As a result of the widespread use of PFAS, these chemicals can be found in surface and groundwater and subsequently in drinking water [86,87]. Studies have described the presence of PFAS in tap water in several countries, and the levels of these chemicals can vary largely depending on the location. In a study in Canada, average concentrations of PFOS and PFOA from the Great Lakes area were $3.4 \mathrm{ng} / \mathrm{L}$ and $1.8 \mathrm{ng} / \mathrm{L}$, respectively, whereas samples from the rest of Canada had average concentrations of 0.4 and $0.7 \mathrm{ng} / \mathrm{L}$, respectively [86]. In Brazil, the average levels of PFOS and PFOA in tap water were $6.7 \mathrm{ng} / \mathrm{L}$ and $2.7 \mathrm{ng} / \mathrm{L}$, whereas in China, they were $3.9 \mathrm{ng} / \mathrm{L}$ and $10 \mathrm{ng} / \mathrm{L}$, respectively [88,89]. In tap water samples from the United States (Ohio and Northern Kentucky), the average concentrations of PFOS and PFOA were $7.6 \mathrm{ng} / \mathrm{L}$ and $10 \mathrm{ng} / \mathrm{L}$, respectively. PFAS have longer half-lives in humans than non-human animals, suggesting that humans could be more susceptible to PFAS toxicity than non-human animals [90-92]. To date, the USEPA does not have MCLs for PFAS in drinking waters, but this agency is analyzing the necessity of creating MCLs for PFOA and PFOS specifically [93]. 


\subsection{Effects of PFAS on the Reproductive System}

\subsubsection{Non-Human Animals}

PFAS are known to disrupt reproductive function in non-human animals. Specifically, PFOA exposure damaged seminiferous tubules, increased spermatogonial apoptosis, and decreased testosterone levels in the testes of mice [19]. Exposure to PFOA decreased the number of mated and pregnant females per male mouse and disrupted blood testis barrier integrity [94]. Further, prenatal exposure to PFOA reduced the number of offspring, caused damage in the testes, disrupted reproductive hormones levels, and reduced expression of the Dlk1-Dio3 imprinted cluster in testes in mice [95]. Prenatal exposure to PFOS decreased sperm count and serum testosterone concentration in male rat offspring [20]. Li et al. demonstrated that rats exposed to PFOS during puberty presented delayed Leydig cell maturation, decreased androgen production, reduced expression of cytochrome P450 11A1 (Cyp11a1), cytochrome P450 17A1 (Cyp17a1), and hydroxysteroid 17-Beta dehydrogenase 3 (Hsd17b3), and they disrupted the expression of apoptotic-related genes BCL2 associated X (Bax) and BCL2 apoptosis regulator (Bcl-2) in Leydig cells [96]. In female mice, PFOA exposure caused a delayed or absence of vaginal opening, lack of estrous cycling, decreased ovarian levels of steroidogenic acute regulatory protein (STAR), CYP11A1, 3-Beta dehydrogenase 1 (HSD3B1), and HSD17B1, and reduced protein levels of amphiregulin and hepatocyte growth factor in the mammary glands [97]. In mice, Chen et al. showed that maternal exposure to PFOA inhibited corpus luteum function, decreased levels of serum progesterone, decreased the ovarian expression of Star, Cyp11a1, and Hsd3b1, increased the ovarian expression of tumor protein (p53) and Bax, and reduced the expression of Bcl-2 in the ovary, leading to embryo resorption, reduced fetal growth, and reduced postnatal survival [98]. Furthermore, PFOA exposure induced apoptosis and necrosis in mouse oocytes, which is likely related to reactive oxygen species (ROS) generation and gap junction intercellular communication disruption between the oocyte and the granulosa cells [99]. Working with female rats, Du et al. found that neonatal and juvenile exposure to PFOA or PFOS dysregulated the hypothalamic-pituitary-gonadal (HPG) axis, leading to advanced puberty onset, increased levels of serum luteinizing hormone and estradiol, and the reduced expression of kisspeptin 1 (Kiss1), kisspeptin 1 receptor (Kiss1r), and estrogen receptor alpha (Esr1) in the hypothalamic anteroventral periventricular and arcuate nuclei [81] (Table 4). 
Table 4. Effects of PFAS on the Reproductive System.

\begin{tabular}{|c|c|c|c|c|c|c|}
\hline Chemical & $\begin{array}{l}\text { Exposure } \\
\text { Window }\end{array}$ & Dose & $\begin{array}{l}\text { Model/Study } \\
\text { Population }\end{array}$ & Effects & Conclusion & Reference \\
\hline PFOA & $\begin{array}{l}\text { Adult } \\
\text { exposure }\end{array}$ & $\begin{array}{l}0,0.31,1.25,5 \text {, and } \\
20 \mathrm{mg} / \mathrm{kg} / \text { day by } \\
\text { oral gavage for } 28 \\
\text { days }\end{array}$ & BALB/c male mice & 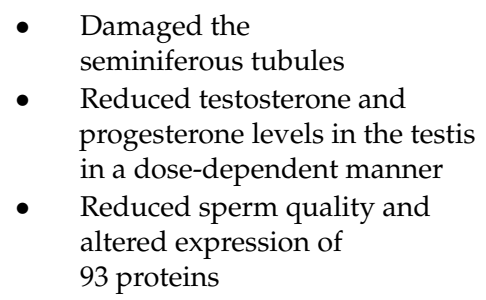 & $\begin{array}{l}\text { PFOA exposure can impair male } \\
\text { reproductive function, possibly by } \\
\text { disturbing testosterone levels, and } \\
\text { CPY11A1 may be a major } \\
\text { steroidogenic enzyme targeted by } \\
\text { PFOA. }\end{array}$ & [19] \\
\hline PFOA & $\begin{array}{l}\text { Adult } \\
\text { exposure } \\
\text { In vitro } \\
\text { exposure of } \\
\text { Sertoli cells }\end{array}$ & $\begin{array}{l}\text { Male mice: } \\
0-20 \mathrm{mg} / \mathrm{kg} / \text { day } \\
\text { by oral gavage for } \\
28 \text { days } \\
\text { Sertoli cells: } \\
0-500 \mu \mathrm{M} \text { for } 48 \mathrm{~h}\end{array}$ & $\begin{array}{l}\text { BALB/c male mice } \\
\text { and Sertoli cells } \\
\text { culture }\end{array}$ & $\begin{array}{l}\text { - Decreased pregnant females } \\
\text { per male mouse, decreased } \\
\text { litter weight } \\
\text { - } \quad \text { Damaged blood-testis barrier } \\
\text { Decreased levels of claudin-11, } \\
\text { connexin-43, } N \text {-cadherin, } \\
\beta \text {-catenin, and occludin in } \\
\text { the testes }\end{array}$ & $\begin{array}{l}\text { Sertoli cells appear to be target of } \\
\text { PFOA and the disruption of the } \\
\text { blood-testis barrier may be crucial } \\
\text { for PFOA-induced reproductive } \\
\text { dysfunction in mice. }\end{array}$ & [94] \\
\hline PFOA & $\begin{array}{l}\text { Gestational } \\
\text { exposure }\end{array}$ & $\begin{array}{l}2.5 \text { or } 5 \mathrm{mg} / \mathrm{kg} \\
\text { PFOA daily by } \\
\text { gavage during } \\
\text { gestation }\end{array}$ & $\begin{array}{l}\text { Kunming mice of } \\
\text { Clean Grade }\end{array}$ & $\begin{array}{l}\text { Decreased survival number of } \\
\text { offspring at weaning } \\
\text { Reduced testosterone in the } \\
\text { male offspring } \\
\text { - } \begin{array}{l}\text { Damage to testis in a } \\
\text { dose-dependent manner }\end{array} \\
\text { - } \quad \begin{array}{l}\text { Decreased number of } \\
\text { Leydig cells }\end{array}\end{array}$ & $\begin{array}{l}\text { PFOA exposure during pregnancy } \\
\text { reduces survival of offspring, } \\
\text { damages the testis, and disrupts } \\
\text { reproductive hormones. }\end{array}$ & [95] \\
\hline
\end{tabular}


Table 4. Cont.

\begin{tabular}{|c|c|c|c|c|c|c|}
\hline Chemical & $\begin{array}{l}\text { Exposure } \\
\text { Window }\end{array}$ & Dose & $\begin{array}{l}\text { Model/Study } \\
\text { Population }\end{array}$ & Effects & Conclusion & Reference \\
\hline PFOS & $\begin{array}{l}\text { Prepubertal } \\
\text { exposure }\end{array}$ & $\begin{array}{l}5 \text { or } 10 \mathrm{mg} / \mathrm{kg} \\
\text { PFOS on postnatal } \\
\text { day } 35 \text { for } 21 \text { days }\end{array}$ & Sprague Dawley rats & $\begin{array}{l}\text { - } \quad \text { Decreased testosterone levels } \\
\text { Downregulated expression of } \\
\text { Lhcgr, Cyp11a1, and Cyp17a1 in } \\
\text { Leydig cells } \\
\text { - Inhibited androgen secretion in } \\
\text { immature Leydig cells } \\
\text { - Increased apoptosis in } \\
\text { Leydig cells }\end{array}$ & $\begin{array}{l}\text { PFOS directly inhibits pubertal } \\
\text { development of Leydig cells. }\end{array}$ & [96] \\
\hline PFOA & $\begin{array}{l}\text { Adult } \\
\text { exposure }\end{array}$ & $\begin{array}{l}\text { Vehicle control or } \\
\text { PFOA at } \\
2.5 \mathrm{mg} / \mathrm{kg} \text { (for } \\
\mathrm{Balb} / \mathrm{c} \mathrm{mice} \text { ) and } \\
7.5 \mathrm{mg} / \mathrm{kg} \text { (for } \\
\mathrm{C} 57 \mathrm{Bl} / 6 \text { wild type } \\
\text { and PPAR } \alpha \\
\text { knockout mice) by } \\
\text { oral gavage, once } \\
\text { daily, } 5 \text { days per } \\
\text { week for } 4 \text { weeks } \\
\text { starting at } 21 \text { days } \\
\text { of age }\end{array}$ & $\begin{array}{l}\text { Balb/c, C57Bl/ } 6 \text { wild } \\
\text { type mice, and } \\
\text { C } 57 \mathrm{Bl} / 6 \text { PPAR } \alpha \\
\text { knockout mice }\end{array}$ & 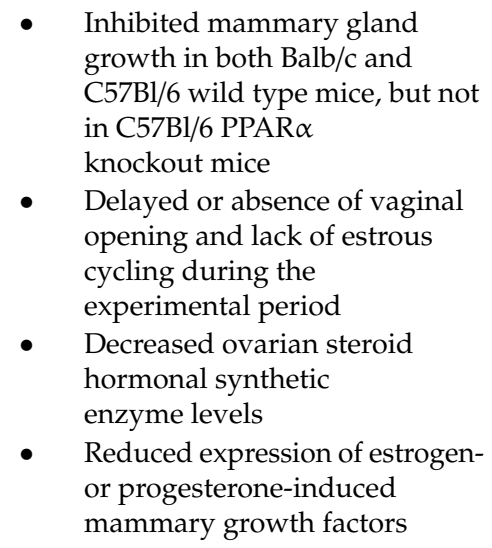 & $\begin{array}{l}\text { The effects of PFOA on the ovaries } \\
\text { mediate its ability to inhibit } \\
\text { mammary gland development in } \\
\text { Balb/c and C57Bl/6 mice. }\end{array}$ & {$[97]$} \\
\hline
\end{tabular}


Table 4. Cont.

\begin{tabular}{|c|c|c|c|c|c|c|}
\hline Chemical & $\begin{array}{l}\text { Exposure } \\
\text { Window }\end{array}$ & Dose & $\begin{array}{l}\text { Model/Study } \\
\text { Population }\end{array}$ & Effects & Conclusion & Reference \\
\hline PFOA & $\begin{array}{l}\text { Gestational } \\
\text { exposure }\end{array}$ & $\begin{array}{l}2.5,5 \text { or } \\
10 \mathrm{mg} / \mathrm{kg} / \text { day of } \\
\text { PFOA by gavage } \\
\text { from gestational } \\
\text { day } 1 \text { until the } \\
\text { day of euthanasia }\end{array}$ & Kunming mice & $\begin{array}{ll}\text { - } & \text { Increased numbers of } \\
\text { - } & \text { resorbed embryos } \\
& \text { progesterone levels } \\
\text { - } & \text { Decreases in transcript levels } \\
\text { for key steroidogenic enzymes } \\
\text { - } & \text { Inhibited activities of } \\
\text { superoxide dismutase } \\
\text { and catalase } \\
\text { Increased generation of } \\
\text { hydrogen peroxide } \\
\text { and malondialdehyde } \\
\text { Down-regulated level of } B c l-2 \\
\text { - Up-regulated p53 and } \\
\text { BAX proteins }\end{array}$ & $\begin{array}{l}\text { PFOA exposure significantly } \\
\text { inhibits luteal function via } \\
\text { oxidative stress and apoptosis in } \\
\text { pregnant mice. }\end{array}$ & [98] \\
\hline PFOA & $\begin{array}{l}\text { In vitro } \\
\text { exposure of } \\
\text { oocytes and } \\
\text { Ex vivo } \\
\text { exposure of } \\
\text { fetal ovaries }\end{array}$ & $\begin{array}{l}\text { In vitro oocytes: } \\
50,100, \text { and } \\
150 \mu \mathrm{M} \text { for } 24 \mathrm{~h} \\
\text { Ex vivo fetal } \\
\text { ovaries: } 28.2 \mu \mathrm{M}\end{array}$ & $\begin{array}{l}\text { CD-1- mice oocytes } \\
\text { CD-1- mice fetal } \\
\text { ovarian tissue }\end{array}$ & $\begin{array}{l}\text { - Induced oocyte apoptosis and } \\
\text { necrosis in vitro } \\
\text { - Increased ROS } \\
\text { - Caused the blockage of GJIC in } \\
\text { cumulus } \\
\text { cells-oocyte complexes }\end{array}$ & $\begin{array}{l}\text { The ability of PFOA to disrupt the } \\
\text { GJIC in COCs, generate ROS in the } \\
\text { fetal ovary, and cause apoptosis } \\
\text { and necrosis in oocytes might } \\
\text { account for the reported } \\
\text { association between increasing } \\
\text { maternal plasma concentrations of } \\
\text { PFOA with reduced fertility in } \\
\text { women. }\end{array}$ & [99] \\
\hline $\begin{array}{l}\text { PFOS, PFOA, and } \\
\text { perfluorohexane sulfonic acid }\end{array}$ & $\begin{array}{l}\text { Adult } \\
\text { exposure }\end{array}$ & $\begin{array}{l}\text { PFOS, PFOA, and } \\
\text { perfluorohexane } \\
\text { sulfonic acid } \\
\text { (medians of } 24.5, \\
4.9, \text { and } 6.6 \mathrm{ng} / \mathrm{mL} \text {, } \\
\text { respectively) }\end{array}$ & $\begin{array}{l}105 \text { Danish men from } \\
\text { the general } \\
\text { population (median } \\
\text { age, } 19 \text { years) }\end{array}$ & $\begin{array}{l}\text { - Men with high combined levels } \\
\text { of PFOS and PFOA had a } \\
\text { median of } 6.2 \text { million normal } \\
\text { spermatozoa in their ejaculate } \\
\text { in contrast to } 15.5 \text { million } \\
\text { among men with } \\
\text { low PFOS-PFOA }\end{array}$ & $\begin{array}{l}\text { High PFAS levels were associated } \\
\text { with fewer normal sperm. High } \\
\text { levels of PFAS may contribute to } \\
\text { the otherwise unexplained low } \\
\text { semen quality often seen in young } \\
\text { men. }\end{array}$ & [100] \\
\hline
\end{tabular}


Table 4. Cont.

\begin{tabular}{|c|c|c|c|c|c|c|}
\hline Chemical & $\begin{array}{l}\text { Exposure } \\
\text { Window }\end{array}$ & Dose & $\begin{array}{l}\text { Model/Study } \\
\text { Population }\end{array}$ & Effects & Conclusion & Reference \\
\hline PFOA, PFOS & $\begin{array}{l}\text { Gestational } \\
\text { exposure }\end{array}$ & $\begin{array}{l}\text { Range of maternal } \\
\text { serum } \\
\text { concentrations of } \\
\text { selected PFAS: } \\
1.26-54.28 \mathrm{ng} / \mathrm{mL}\end{array}$ & $\begin{array}{l}169 \text { male offspring } \\
\text { (19-21 years of age) } \\
\text { from a pregnancy } \\
\text { cohort established in } \\
\text { Aarhus, Denmark, in } \\
\text { 19881989- }\end{array}$ & $\begin{array}{l}\text { - In utero exposure to PFOA was } \\
\text { associated with lower adjusted } \\
\text { sperm concentration and total } \\
\text { sperm count and with higher } \\
\text { adjusted levels of luteinizing } \\
\text { hormone and } \\
\text { follicle-stimulating hormone }\end{array}$ & $\begin{array}{l}\text { In utero exposure to PFOA may } \\
\text { affect adult human male semen } \\
\text { quality and reproductive hormone } \\
\text { levels. }\end{array}$ & {$[101]$} \\
\hline PFOA & $\begin{array}{l}\text { In vitro } \\
\text { human } \\
\text { semen } \\
\text { exposure }\end{array}$ & $\begin{array}{l}\text { PFOA } 0.25,2.5 \text { or } \\
25 \mu \mathrm{g} / \mathrm{mL} \text { alone or } \\
\text { in combination } \\
\text { with progesterone }\end{array}$ & Mature human sperm & $\begin{array}{l}\text { - Reduced capacity of human } \\
\text { spermatozoa to penetrate } \\
\text { synthetic mucus } \\
\text { - Increased production of } \\
\text { reactive oxygen species } \\
\text { - Compromised } \\
\text { progesterone-induced } \\
\text { acrosome reaction and sperm } \\
\text { penetration into } \\
\text { viscous medium }\end{array}$ & $\begin{array}{l}\text { PFOA exposure may impair } \\
\text { human sperm function through } \\
\text { inducing oxidative stress and } \\
\text { disturbing progesterone-induced } \\
\mathrm{Ca}^{2+} \text { signaling. }\end{array}$ & [102] \\
\hline $\begin{array}{l}\text { Perfluorodecanoic acid, } \\
\text { perfluorohexane sulfonic acid, } \\
\text { perfluorononanoic acid, PFOA, } \\
\text { PFOS, perfluorododecanoic acid, } \\
\text { perfluoroheptanoic acid, } \\
\text { perfluorooctanesulfonamide, and } \\
\text { perfluoroundecanoic acid } \\
\text { measured in serum }\end{array}$ & $\begin{array}{l}\text { Adult } \\
\text { exposure }\end{array}$ & $\begin{array}{l}\text { Range of serum } \\
\text { perfluorochemical } \\
\text { concentration: } \\
0-43.2229 \mathrm{ng} / \mathrm{mL}\end{array}$ & $\begin{array}{l}\text { Operative sample: } \\
495 \text { women aged } \\
18-44 \text { years from } \\
\text { clinical sites in the } \\
\text { Salt Lake City or San } \\
\text { Francisco area, US } \\
2007-2009 \\
\text { Second sample: } 131 \\
\text { women that matched } \\
\text { to the operative } \\
\text { sample on age and } \\
\text { residence within a } \\
\text { 50-mile radius of } \\
\text { participating clinics }\end{array}$ & $\begin{array}{l}\text { - Serum PFOA and } \\
\text { perfluorononanoic acid were } \\
\text { associated with endometriosis } \\
\text { in the operative sample } \\
\text { - Perfluorooctane sulfonic acid } \\
\text { and PFOA increased the odds } \\
\text { for } \\
\text { moderate/severe endometriosis }\end{array}$ & $\begin{array}{l}\text { Select PFAS are associated with } \\
\text { endometriosis diagnosis. }\end{array}$ & [103] \\
\hline
\end{tabular}


Table 4. Cont.

\begin{tabular}{|c|c|c|c|c|c|c|}
\hline Chemical & $\begin{array}{l}\text { Exposure } \\
\text { Window }\end{array}$ & Dose & $\begin{array}{l}\text { Model/Study } \\
\text { Population }\end{array}$ & Effects & Conclusion & Reference \\
\hline $\begin{array}{l}\text { PFOA, PFOS, perfluorohexane } \\
\text { sulfonic acid, 2-(N-ethyl-PFOSA) } \\
\text { acetate, 2-(N-methyl-PFOSA) } \\
\text { acetate, perfluorodecanoic acid, } \\
\text { perfluorobutane sulfonate, } \\
\text { perfluoroheptanoic acid, } \\
\text { perfluorononanoic acid (PFNA), } \\
\text { perfluorooctane sulfonamide, } \\
\text { perfluoroundecanoic acid, and } \\
\text { perfluorododecanoic acid } \\
\text { measured in serum }\end{array}$ & $\begin{array}{l}\text { Adult } \\
\text { exposure }\end{array}$ & $\begin{array}{l}\text { Range of serum } \\
\text { concentratios of } \\
\text { selected PFAS: } \\
0.07-392 \mathrm{ng} / \mathrm{mL}\end{array}$ & $\begin{array}{l}753 \text { women aged } \\
20-50 \text { years from the } \\
\text { National Health and } \\
\text { Nutrition } \\
\text { Examination Survey } \\
\text { (2003-2006) in US }\end{array}$ & $\begin{array}{l}\text { - Geometric mean levels of } \\
\text { perfluorononanoic acid, PFOA, } \\
\text { and PFOS were higher among } \\
\text { women reporting } \\
\text { endometriosis and } \\
\text { endometriosis was associated } \\
\text { with select quartiles of PFOA, } \\
\text { PFNA, and PFOS }\end{array}$ & $\begin{array}{l}\text { PFOA, PFNA, and PFOS may be } \\
\text { associated with an increased risk } \\
\text { of endometriosis. }\end{array}$ & [104] \\
\hline $\begin{array}{l}\text { Perfluorododecanoic acid, } \\
\text { perfluoroundecanoic acid, } \\
\text { perfluorodecanoic acid, } \\
\text { perfluorooctane sulfonamide, } \\
\text { PFOS, PFOA, perfluoroheptanoic } \\
\text { acid, perfluorohexane sulfonic } \\
\text { acid, perfluorobutane sulfonic } \\
\text { acid (PFBS) measured in plasma }\end{array}$ & $\begin{array}{l}\text { Adult } \\
\text { exposure }\end{array}$ & $\begin{array}{l}\text { Range of plasma } \\
\text { concentratios of } \\
\text { selected PFAS: } \\
0.006-138 \mathrm{ng} / \mathrm{mL}\end{array}$ & $\begin{array}{l}157 \text { Chinese women } \\
\text { aged } 20-45 \text { surgically } \\
\text { confirmed } \\
\text { endometriosis cases } \\
\text { and } 178 \text { seeking } \\
\text { infertility treatment } \\
\text { because of male } \\
\text { reproductive } \\
\text { dysfunction in } 2014 \\
\text { and } 2015\end{array}$ & $\begin{array}{l}\text { Plasma concentrations of PFBS } \\
\text { were associated with an } \\
\text { increased risk of } \\
\text { endometriosis-related infertility }\end{array}$ & $\begin{array}{l}\text { Exposure to PFBS may increase the } \\
\text { risk of female infertility due to } \\
\text { endometriosis. }\end{array}$ & [105] \\
\hline $\begin{array}{l}\text { PFOA, PFOS perfluorohexane } \\
\text { sulfonic acid, 2-(N-ethyl-PFOSA) } \\
\text { acetate (EPAH), } \\
\text { 2-(N-methyl-PFOSA) acetate, } \\
\text { perfluorodecanoic acid, } \\
\text { perfluorobutane sulfonate, } \\
\text { perfluoroheptanoic acid, } \\
\text { perfluorononanoic acid (PFNA), } \\
\text { perfluorooctane sulfonamide, } \\
\text { perfluoroundecanoic acid, } \\
\text { perfluorooctanesulfonic, and } \\
\text { perfluorododecanoic acid } \\
\text { measured in blood }\end{array}$ & $\begin{array}{l}\text { Adult } \\
\text { exposure }\end{array}$ & N/A & $\begin{array}{l}178 \text { healthy, naturally } \\
\text { cycling women, aged } \\
25-35 \text { years in } \\
\text { Tromsø, Norway }\end{array}$ & $\begin{array}{l}\text { PFOS blood concentrations } \\
\text { were inversely associated with } \\
\text { salivary concentration of } \\
\text { estradiol and progesterone } \\
\text { - } \quad \text { Similar, but weaker results } \\
\text { were observed for PFOA }\end{array}$ & $\begin{array}{l}\text { PFOS and perfluorooctanesulfonic } \\
\text { acid may be associated with } \\
\text { decreased production of estradiol } \\
\text { and progesterone in } \\
\text { reproductive-age women. }\end{array}$ & [106] \\
\hline
\end{tabular}


Table 4. Cont

\begin{tabular}{|c|c|c|c|c|c|c|}
\hline Chemical & $\begin{array}{l}\text { Exposure } \\
\text { Window }\end{array}$ & Dose & $\begin{array}{l}\text { Model/Study } \\
\text { Population }\end{array}$ & Effects & Conclusion & Reference \\
\hline $\begin{array}{l}\text { Perfluorohexanesulfonate } \\
\text { (PFHxS), perfluoroheptanoic acid } \\
\text { (PFHpA), perfluorononanoic } \\
\text { acid (PFNA), perfluorooctanoic } \\
\text { acid (PFOA), perfluorooctyl } \\
\text { sulfonate (PFOS), } \\
\text { perfluorodecanoic acid (PFDeA), } \\
\text { perfluoroundecanoic acid } \\
\text { (PFUA), perfluorododecanoic } \\
\text { acid (PFDoA), } \\
\text { 2-(N-methyl-perfluorooctane } \\
\text { sulfonamido) acetic acid } \\
\text { (Me-PFOSA-AcOH), } \\
\text { 2-(N-ethylperfluorooctane } \\
\text { sulfonamido) acetic acid } \\
\text { (Et-PFOSA-AcOH), } \\
\text { perfluorohexanoic acid (PFHxA), } \\
\text { and perfluorooctane sulfonamide } \\
\text { (PFOSA) measured in serum }\end{array}$ & $\begin{array}{l}\text { Adult } \\
\text { exposure }\end{array}$ & $\begin{array}{l}\text { Range of serum } \\
\text { concentratios of } \\
\text { selected PFAS: } \\
3.63-13.41 \mathrm{ng} / \mathrm{mL}\end{array}$ & $\begin{array}{l}540 \text { subjects aged } \\
12-30 \text { years from a } \\
1992 \text { to } 2000 \text { in Taiwan }\end{array}$ & $\begin{array}{l}\text { The adjusted mean serum level } \\
\text { of sex hormone-binding } \\
\text { globulin decreased in } \\
\text { association with PFOA } \\
\text { blood concentration } \\
\text { Follicle-stimulating hormone } \\
\text { levels were decreased in } \\
\text { association with PFOS in the } \\
\text { male 1217-year-old group and } \\
\text { with perfluoroundecanoic acid } \\
\text { (PFUA) in the female } \\
\text { 1217-year-old group }\end{array}$ & $\begin{array}{l}\text { Serum concentrations of PFOA, } \\
\text { PFOS, and PFUA were negatively } \\
\text { associated with the serum levels of } \\
\text { sex hormone-binding globulin, } \\
\text { follicle-stimulating hormone, and } \\
\text { testosterone in young Taiwanese } \\
\text { population and these effects were } \\
\text { the strongest in the females aged } \\
12-17 .\end{array}$ & [107] \\
\hline PFOA, PFOS measured in plasma & $\begin{array}{l}\text { Gestational } \\
\text { exposure }\end{array}$ & $\begin{array}{l}\text { PFOS and PFOA } \\
\text { levels in maternal } \\
\text { plasma were on } \\
\text { average } 35.3 \text { and } \\
5.6 \mathrm{ng} / \mathrm{mL}, \\
\text { respectively }\end{array}$ & $\begin{array}{l}1400 \text { women and their } \\
\text { infants from the } \\
\text { Danish National Birth } \\
\text { Cohort }\end{array}$ & $\begin{array}{l}\text { - } \quad \text { PFOA levels were inversely } \\
\text { associated with birth weight }\end{array}$ & $\begin{array}{l}\text { Maternal plasma PFOA levels are } \\
\text { inversely associated with birth } \\
\text { weight. }\end{array}$ & [108] \\
\hline $\begin{array}{l}\text { PFOS, PFOA, and } \\
\text { perfluorohexane sulfonate } \\
\text { (PFHxS) measured in serum }\end{array}$ & $\begin{array}{l}\text { Maternal } \\
\text { exposure }\end{array}$ & $\begin{array}{l}\text { Range of serum } \\
\text { concentratios of } \\
\text { selected PFAS: } \\
0.1-36 \mathrm{ng} / \mathrm{mL}\end{array}$ & $\begin{array}{l}\text { The Maternal-Infant } \\
\text { Research on } \\
\text { Environmental } \\
\text { Chemicals Study is a } \\
\text { cohort study of 2,001 } \\
\text { women recruited } \\
\text { before } 14 \text { weeks of } \\
\text { gestation in } 10 \text { cities } \\
\text { across Canada } \\
\text { between } 2008 \text { and } \\
2011\end{array}$ & $\begin{array}{l}\text { PFOA and PFHxS were } \\
\text { associated with a } 11 \text { and } 9 \% \\
\text { reduction in fecundability } \\
\text { The odds of infertility increased } \\
\text { by } 31 \% \text { per one standard } \\
\text { deviation increase of PFOA }\end{array}$ & $\begin{array}{l}\text { Exposure to PFOA and PFHxS, } \\
\text { even at lower levels than } \\
\text { previously reported, may reduce } \\
\text { fecundability. }\end{array}$ & [109] \\
\hline
\end{tabular}


Table 4. Cont.

\begin{tabular}{|c|c|c|c|c|c|c|}
\hline Chemical & $\begin{array}{l}\text { Exposure } \\
\text { Window }\end{array}$ & Dose & $\begin{array}{l}\text { Model/Study } \\
\text { Population }\end{array}$ & Effects & Conclusion & Reference \\
\hline $\begin{array}{l}\text { PFHxS, PFOS, PFOA, PFNA, } \\
\text { perfluorodecanoic acid (PFDA), } \\
\text { perfluorodecane sulfonate, } \\
\text { perfluoroundecanoic acid, } \\
\text { perfluorododecanoic acid, } \\
\text { perfluorotridecanoic acid, } \\
\text { perfluorotetradecanoic acid, and } \\
\text { perfluorohexadecanoic acid } \\
\text { measured in maternal plasma }\end{array}$ & $\begin{array}{l}\text { Maternal } \\
\text { exposure }\end{array}$ & $\begin{array}{l}\text { Range of plasma } \\
\text { concentratios of } \\
\text { selected PFAS: } \\
0.01-500 \mathrm{ng} / \mathrm{mL}\end{array}$ & $\begin{array}{l}1292 \text { pregnant women } \\
\text { in Shanghai, China, } \\
2012\end{array}$ & $\begin{array}{l}\text { Maternal plasma } \\
\text { concentrations of PFOS, PFDA, } \\
\text { and perfluoroundecanoic acid } \\
\text { were inversely associated with } \\
\text { anogenital distance at birth in } \\
\text { male offspring }\end{array}$ & $\begin{array}{l}\text { Higher maternal concentrations of } \\
\text { some PFAS during pregnancy are } \\
\text { associated with shorter anogenital } \\
\text { distance in male infants. }\end{array}$ & [110] \\
\hline PFOA & $\begin{array}{l}\text { Adult } \\
\text { exposure } \\
\text { and in vitro } \\
\text { exposure of } \\
\text { Ishikawa } \\
\text { cells }\end{array}$ & N/A & $\begin{array}{l}146 \text { exposed females } \\
\text { aged } 18-21 \text { from the } \\
\text { Veneto region in Italy } \\
\text { and } 1080 \text { non-exposed } \\
\text { controls andhuman } \\
\text { endometrial Ishikawa } \\
\text { cells }\end{array}$ & $\begin{array}{l}\text { Dysregulation of the genetic } \\
\text { cascade leading to embryo } \\
\text { implantation and } \\
\text { endometrial receptivity } \\
\text { Molecular interference } \\
\text { with progesterone } \\
\text { Increased age at menarche } \\
(+164 \text { days, } p=0.006) \text { and } \\
\text { frequency of girls with } \\
\text { irregular periods }\end{array}$ & $\begin{array}{l}\text { PFAS have endocrine-disrupting } \\
\text { activity on progesterone-mediated } \\
\text { endometrial function. }\end{array}$ & [111] \\
\hline PFOA and PFOS & $\begin{array}{l}\text { Adult } \\
\text { exposure } \\
\text { nd in vitro } \\
\text { exposure of } \\
\text { HeLa cells }\end{array}$ & $\begin{array}{l}\text { Range of serum } \\
\text { concentratios of } \\
\text { PFOA and PFOS: } \\
0-156.7 \mathrm{ng} / \mathrm{mL} \\
\text { In vitro exposure: } \\
1 \mu \mathrm{M} \text { PFOA or } \\
\text { PFOS }\end{array}$ & $\begin{array}{l}212 \text { exposed males } \\
\text { and } 171 \text { non-exposed } \\
\text { males controls in } \\
\text { Veneto Region, Italy } \\
\text { from } 2017 \text { to } 2018\end{array}$ & $\begin{array}{l}\text { - Reduced semen quality, } \\
\text { testicular volume, penile length, } \\
\text { and anogenital distance } \\
\text { - Antagonistic effect of PFOA on } \\
\text { testosterone and androgen } \\
\text { receptor binding }\end{array}$ & $\begin{array}{l}\text { PFOA and PFOS exposure affects } \\
\text { androgenic function and impairs } \\
\text { reproductive outcomes in males. }\end{array}$ & [112] \\
\hline
\end{tabular}




\subsubsection{Humans}

PFAS have been associated with reproductive and fertility dysfunction in men and women. In an epidemiologic study in Denmark, men with high combined semen levels of PFOS and PFOA had decreased normal sperm numbers compared to men with low semen levels of PFOS and PFOA [100]. In another study in Denmark, in utero exposure to PFOA was associated with lower sperm concentration and total sperm count in adult men [101]. Further, in vitro exposure to PFOA impaired human sperm penetration in synthetic mucus, which was likely caused by excessive ROS production, compromising human sperm penetration ability and acrosome reaction by canceling progesterone-induced $\mathrm{Ca}^{2+}$ signaling [102]. In addition, men exposed to PFOA for up to $2 \mathrm{~h}$ exhibited altered sperm motility due to plasma-membrane disruption [21]. In China, maternal exposure to PFAS was associated with shorter anogenital distance in boys, providing evidence that PFAS may function as EDCs to affect male genital development [110]. Moreover, PFOA and PFOS exposure were associated with reduced semen quality, testicular volume, penile length, and anogenital distance in men in the Veneto region, Italy. This same study demonstrated that PFOA plays an antagonistic role on the binding of testosterone to androgen receptor, possibly dysregulating the HPG axis [112] (Table 4).

In women, exposure to PFAS has been associated with endometriosis in the US and China [103-105]. Further, levels of PFAS in blood have been associated with decreased serum levels of estradiol, progesterone, sex hormone-binding globulin, follicle-stimulating hormone (FSH), and testosterone [106,107]. Plasma concentrations of PFAS in pregnant women in the Danish National Birth Cohort were associated with low birth weight and long time to pregnancy [22,108]. Moreover, the maternal-infant research on environmental chemicals study, a cohort study of pregnant women across Canada, showed that plasma levels of PFOA and PFHxS were associated with reduced fecundability [109]. In Swedish women, prenatal exposure to PFOA was associated with higher odds for small for gestational age [113]. In a recent study, PFAS exposure was associated with increased age at menarche and irregular menstrual periods in young women. The same study reported a significant alteration in the expression of genes related to embryo implantation in Ishikawa cells exposed to PFOA compared to non-exposed cells [111] (Table 4).

Although several studies have shown that PFAS exposure causes adverse reproductive and health effects, little is known about emerging PFAS and their effects on the environment and human health. For example, perfluoro-2-propoxypropanoic acid (PFECA), a PFOA replacement known as "GenX", has been shown to have higher toxicity than PFOA when correcting for differences in toxicokinetics. However, the effects of "GenX" on reproductive outcomes are unclear [114]. In addition, few studies have examined the effects of exposure to a mixture of PFAS on non-human animal and human health, which could provide more information about the potential interactions between individual PFAS. Future studies should include these factors to improve our understanding of PFAS toxicity and adverse health outcomes.

\section{Bisphenol A}

Bisphenol A (BPA) is an important compound in the bisphenol (bishydroxyarylalkanes) group [115]. Currently, BPA is a high production volume chemical that is widely used in manufacturing polycarbonate plastics and epoxy resins for industrial use [116]. Polycarbonate plastics are used in food and drink packaging (water and infant bottles, compact discs, impact-resistant safety equipment, medical devices), whereas epoxy resins are used as lacquers to coat metal products (food cans, bottle tops, water supply pipes) [117]. Human exposure to BPA is a public health concern because BPA has the ability to bind membrane and nuclear receptors such as androgen, estrogen, and thyroid receptors, causing endocrine disruption, tumors, adverse reproductive outcomes, and transgenerational effects [118-122]. 


\subsection{Sources of Exposure to BPA}

The primary source of exposure to BPA is diet, but BPA is ubiquitous in the environment, air, dust, and water. BPA can leach into food from the protective internal epoxy resin coatings of canned foods and from consumer products such as polycarbonate tableware, food storage containers, water bottles, and baby bottles [117]. Canada was the first country to prohibit the sale and importation of BPA-containing baby bottles [123]. Several states in the US banned the use of BPA in cups, bottles, thermoses, baby food and infant formula containers, or thermal paper [124]. Further, the French National Assembly and Senate suspended the use of BPA in all applications that have contact with food [125]. In contrast, the European Food Safety Authority concluded that BPA was not a threat for the health of consumers of any age. In addition, the United States Food and Drug Administration (USFDA) declared that BPA is safe at the current levels occurring in foods [126]. Although controversies about BPA regulation exist, studies have shown that this chemical is an endocrine disruptor, which means that this compound is able to trigger adverse health effects at low and environmentally relevant doses [127,128].

BPA is ubiquitous in aquatic environments and can be detected in rivers, effluent from sewage treatment plants, and water from water treatment plants $[129,130]$. Specifically, the mean concentrations of BPA in the Huangpu River in China were $22.93 \mathrm{ng} / \mathrm{L}$ in surface waters, $84.11 \mathrm{ng} / \mathrm{g}$ in suspended solids, and $7.13 \mathrm{ng} / \mathrm{g}$ dry weight in surface sediments [130]. Further, a study in Taiwan determined that BPA concentrations in drinking water were increased with contact time in polyvinyl chloride (PVC) pipes [131]. In some provinces of South Africa, BPA was found to be present in $62 \%$ of the analyzed drinking water and wastewater samples [132]. Further, in raw water and tap water samples in France, BPA levels were up to $1430 \mathrm{ng} / \mathrm{L}$ and between 9 and $50 \mathrm{ng} / \mathrm{L}$, respectively [133]. In wastewater treatment plants, BPA was found at concentrations of $60.5 \mathrm{ng} / \mathrm{L}$ in five states in India, $1960 \mathrm{ng} / \mathrm{L}$ in 49 samples from Xiamen City in China, and $412 \mathrm{ng} / \mathrm{L}$ in one sample from Dalian City, China [134-136]. The USEPA reported that BPA concentrations in US drinking water are typically below $1 \mu \mathrm{g} / \mathrm{L}$ [137]. Although exposure to BPA through tap water is a minor source of human BPA exposure, bottled mineral water may also lead to exposure [138].

\subsection{Effects of BPA on the Reproductive System}

\subsubsection{Non-Human Animals}

BPA is known to cause adverse reproductive outcomes in non-human animals. Specifically, it has been demonstrated that BPA disrupts the HPG axis in mice, rats, and zebrafish [139-144]. In mice, studies have shown that BPA exposure reduced sperm motility, reduced normal sperm morphology, decreased sperm membrane integrity, decreased sperm count, impaired sperm function, induced spermatocyte apoptosis, and impacted testicular development [145-149]. In females, BPA exposure is known to cause altered mammary gland development and morphology. Specifically, in utero exposure to BPA resulted in altered development, increased epithelial volume, and the altered ductal morphology of mammary glands in mice [121,150]. Further, Ibrahim et al. showed that adult BPA exposure increased the number of the ducts and acini of the mammary gland, with hyperplasia in their lining epithelium in rats [151]. These studies agree that mammary gland changes due to BPA could lead eventually to an increased incidence of mammary gland cancer [119] (Table 5).

Exposure to BPA has been shown to affect the ovaries. Prenatal BPA exposure inhibited germ cell nest breakdown in ovaries of the F1 generation in mice, decreased the numbers of primordial, primary, preantral, and total healthy follicle numbers at post-natal day 21, and decreased estradiol levels in female rats dosed for 1 year, suggesting that BPA targets the ovary [11,12]. Further, BPA exposure initiated an excessive premature activation of primordial follicles in mouse mature ovaries via the phosphatase and tensin homolog/phosphatidylinositol-3-kinase/ protein kinase B (PTEN/PI3K/AKT) signaling pathway by downregulating phosphatase and tensin homolog (PTEN) expression in vivo [152] (Table 5). 
Table 5. Effects of BPA on the Reproductive System.

\begin{tabular}{|c|c|c|c|c|c|c|}
\hline Chemical & $\begin{array}{l}\text { Exposure } \\
\text { Window }\end{array}$ & Dose & $\begin{array}{l}\text { Model/Study } \\
\text { Population }\end{array}$ & Effects & Conclusion & Reference \\
\hline BPA & $\begin{array}{l}\text { Adult } \\
\text { exposure }\end{array}$ & $\begin{array}{l}\text { Oral administration of } \\
\text { corn oil or } 20 \mu \mathrm{g} / \mathrm{kg} \text { of } \\
\text { BPA } \\
\text { Injection of } 0,0.02,0.2 \text {, } \\
\text { 2.0, 20.0, and } 200.0 \mathrm{nM} \text { of } \\
\text { BPA into the right lateral } \\
\text { ventricle }\end{array}$ & ICR female mice & $\begin{array}{l}\text { - Oral administration of BPA at proestrus } \\
\text { increased the levels of plasma estradiol, LH } \\
\text { and FSH, and Gnrh mRNA } \\
\text { - Oral administration of BPA at proestrus } \\
\text { elevated the levels of Kiss1 mRNA and } \\
\text { kisspeptin protein in anteroventral } \\
\text { periventricular nucleus (AVPV) } \\
\text { At proestrus, a single injection of BPA } \\
\text { enhanced AVPV-kisspeptin expression and } \\
\text { elevated the levels of plasma } E_{2}, \mathrm{LH} \text {, and } \\
\text { Gnrh mRNA }\end{array}$ & $\begin{array}{l}\text { Exposure of adult female mice to a low } \\
\text { dose of BPA disrupts the } \\
\text { hypothalamic-pituitary-gonadal } \\
\text { reproductive endocrine system through } \\
\text { enhancing AVPV-kisspeptin expression } \\
\text { and release. }\end{array}$ & [139] \\
\hline BPA & $\begin{array}{l}\text { Gestational } \\
\text { exposure }\end{array}$ & $\begin{array}{l}0,8,40 \text { and } 200 \mathrm{mg} / \mathrm{kg} \text { by } \\
\text { gavage from gestational } \\
\text { day } 0 \text { to } 18\end{array}$ & CD-1 mice & $\begin{array}{l}\text { - } \quad \text { Accelerated vaginal opening } \\
\text { - }\end{array}$ & $\begin{array}{l}\text { Maternal exposure to BPA resulted in } \\
\text { advancing puberty and increased GnRH } \\
\text { hormone levels, affecting the function of } \\
\text { the HPG axis in female offspring. }\end{array}$ & [140] \\
\hline BPA & $\begin{array}{l}\text { Gestational } \\
\text { exposure }\end{array}$ & $\begin{array}{l}\text { Dimethylsulfoxide } \\
\text { vehicle-treated, } 25 \mu \mathrm{g} / \mathrm{kg} \text {, } \\
\text { and } 250 \mu \mathrm{g} / \mathrm{kg} \\
\text { (subcutaneous injections) }\end{array}$ & Wistar rats & $\begin{array}{l}\text { - } \quad \text { Enlarged layer of fibroblasts in the prostatic } \\
\text { periductal stroma } \\
\text { - Increased cellular proliferation in the stroma } \\
\text { - Decreased expression of androgen receptor in } \\
\text { prostatic stromal cells and prostatic acid } \\
\text { phosphatase in epithelial cells }\end{array}$ & $\begin{array}{l}\text { Prenatal exposure to environmental } \\
\text { doses of BPA induced both transient and } \\
\text { permanent age-dependent alterations in } \\
\text { the male reproductive axis at different } \\
\text { levels. }\end{array}$ & [141] \\
\hline
\end{tabular}


Table 5. Cont.

\begin{tabular}{|c|c|c|c|c|c|c|}
\hline Chemical & $\begin{array}{l}\text { Exposure } \\
\text { Window }\end{array}$ & Dose & $\begin{array}{l}\text { Model/Study } \\
\text { Population }\end{array}$ & Effects & Conclusion & Reference \\
\hline BPA & $\begin{array}{l}\text { Gestational } \\
\text { exposure }\end{array}$ & $\begin{array}{l}\text { Corn oil, } 25 \mathrm{mg} \\
\mathrm{BPA} / \mathrm{kg} / \text { day, or } 50 \mathrm{mg} \\
\mathrm{BPA} / \mathrm{kg} / \text { day by gavage }\end{array}$ & $\begin{array}{l}\text { Six-week-old male and } \\
\text { female CD-1 mice }\end{array}$ & $\begin{array}{l}\text { - Up-regulated Kiss1, GnRH and Fsh mRNA in } \\
\text { both male and female pups } \\
\text { - Inhibited expression of testicular } \\
\text { steroidogenic enzymes and synthesis of } \\
\text { testosterone in the male pups } \\
\text { - Increased aromatase expression and synthesis } \\
\text { of estrogen in the female pups }\end{array}$ & $\begin{array}{l}\text { The effects of BPA on reproductive } \\
\text { dysfunction may be due to its actions on } \\
\text { gonadal steroidogenesis and on the } \\
\text { anomalous releases of endogenous } \\
\text { steroid hormones. }\end{array}$ & [142] \\
\hline BPA & $\begin{array}{l}\text { Adult } \\
\text { exposure }\end{array}$ & 5 or $25 \mathrm{mg} \mathrm{BPA} / \mathrm{kg} /$ day & Wistar rats & $\begin{array}{l}\text { - Reduced sperm production, reserves, and } \\
\text { transit time } \\
\text { - Increased levels of defective spermatozoa } \\
\text { - Increased expression } G n r h r, L h b, F s h b, E s r 2, \\
\text { and } A r \text { in the pituitary and reduced } \\
\text { expression of Esr1 in the hypothalamus } \\
\text { - Reduced serum concentrations of } \\
\text { testosterone, LH and FSH and increased } \\
\text { concentration of estradiol }\end{array}$ & $\begin{array}{l}\text { At dosages previously considered } \\
\text { nontoxic to reproductive function, BPA } \\
\text { compromises spermatozoa and disrupts } \\
\text { the hypothalamic-pituitary-gonadal axis, } \\
\text { causing a state of hypogonadotropic } \\
\text { hypogonadism. }\end{array}$ & [143] \\
\hline BPA & $\begin{array}{l}\text { Adult } \\
\text { exposure }\end{array}$ & $\begin{array}{l}\text { Control, 1, 10, } 100 \text { and } \\
1000 \mu \mathrm{g} / \mathrm{L}\end{array}$ & Zebra fish & $\begin{array}{l}\text { Decreased and increased expression of } \\
\text { Cyp } 19 b \text { depending on the dose }\end{array}$ & $\begin{array}{l}\text { BPA dysregulates gonadotropic } \\
\text { hormones, causing degeneration of } \\
\text { gonadotropic cells. }\end{array}$ & [144] \\
\hline BPA & $\begin{array}{l}\text { Neonatal } \\
\text { exposure }\end{array}$ & $\begin{array}{l}\text { Daily subcutaneous } \\
\text { injections of } 0.5 \text { or } 50 \mu \mathrm{g} \\
\text { BPA, } 50 \mu \mathrm{g} \text { BPA plus } 100 \\
\text { IU retinol acetate or the } \\
\text { vehicle only, for } 5 \text { days } \\
\text { from the day of birth. }\end{array}$ & SHN mice & $\begin{array}{l}\text { - Decreased percentage of moving sperm, } \\
\text { - Increased incidence of malformed sperm } \\
\text { ame deteriorating effects of } 50 \mu \mathrm{\mu g} \text { of BPA were } \\
\text { of } 100 \mathrm{IU} \text { of by the concunol acetate }\end{array}$ & $\begin{array}{l}\text { Neonatal exposure to a relatively large } \\
\text { dose of BPA causes damage to the } \\
\text { motility and morphology of sperm, but } \\
\text { the BPA effect is, to some extent, } \\
\text { inhibited by a supplement of retinol } \\
\text { acetate, and enhanced under a retinol } \\
\text { acetate deficiency condition. }\end{array}$ & [145] \\
\hline
\end{tabular}


Table 5. Cont.

\begin{tabular}{|c|c|c|c|c|c|c|}
\hline Chemical & $\begin{array}{l}\text { Exposure } \\
\text { Window }\end{array}$ & Dose & $\begin{array}{l}\text { Model/Study } \\
\text { Population }\end{array}$ & Effects & Conclusion & Reference \\
\hline BPA & $\begin{array}{l}\text { Pubertal } \\
\text { exposure }\end{array}$ & $\begin{array}{l}\mathrm{BPA}(5,10, \text { and } 20 \mathrm{mg} / \mathrm{kg}) \\
\text { X-rays }(0.05 \mathrm{~Gy}) \text {, or a } \\
\text { combination of both }(0.05 \\
\text { Gy }+5 \mathrm{mg} / \mathrm{kg} \mathrm{BPA})\end{array}$ & Pzh:Sfis mice & $\begin{array}{l}\text { - BPA and X-rays alone diminished } \\
\text { sperm quality } \\
\text { BPA exposure significantly reduced sperm } \\
\text { count in pubescent males compared to adult } \\
\text { mice, with degenerative changes detected in } \\
\text { seminiferous epithelium } \\
\text { - Increased vacuolization of Sertoli cells and } \\
\text { spermatogonia in animals treated with BPA } \\
\text { and X-rays }\end{array}$ & $\begin{array}{l}\text { Combined BPA with X-ray treatment } \\
\text { enhanced the harmful effect induced by } \\
\text { BPA alone in male germ cells of adult } \\
\text { males, whereas low-dose irradiation } \\
\text { showed sometimes protective or } \\
\text { additive effects in pubescent mice. }\end{array}$ & [146] \\
\hline BPA & $\begin{array}{l}\text { Gestational } \\
\text { exposure }\end{array}$ & $\begin{array}{l}\text { Water (negative control), } \\
\text { olive Oil (vehicle control), } \\
\text { diethylstilbestrol } \\
\text { (DES-positive } \\
\text { control-6.5 } \mu \mathrm{g} / \mathrm{kg} \text {, and } \\
\text { BPA }(40,80 \text { and } \\
200 \mu \mathrm{g} / \mathrm{kg})\end{array}$ & Vesper mice & $\begin{array}{l}\text { BPA reduced normal sperm morphology, } \\
\text { sperm membrane integrity, sperm motility, } \\
\text { and in vitro penetration rates }\end{array}$ & $\begin{array}{l}\text { In utero exposure to BPA caused a } \\
\text { reduction in sperm parameters of adult } \\
\text { C. laucha. }\end{array}$ & [147] \\
\hline BPA & $\begin{array}{l}\text { Adult } \\
\text { exposure }\end{array}$ & $\begin{array}{l}0,10,50 \text {, and } 250 \mu \mathrm{g} / \mathrm{kg} \\
\text { were administrated orally } \\
\text { to for } 8 \text { weeksor applied } \\
\text { directly to normal mouse } \\
\text { sperm in vitro }\end{array}$ & C57BL/6 mice & $\begin{array}{l}\text { Decreased sperm motility and acrosome } \\
\text { reaction in BPA treated mice } \\
\text { Inhibited CatSper transiently and reduced } \\
\text { sperm total motility and acrosome reaction } \\
\text { ratio in vitro }\end{array}$ & $\begin{array}{l}\text { Both in vivo administration and in vitro } \\
\text { application of BPA impaired mature } \\
\text { sperm function by a CatSper-relevant } \\
\text { mechanism. }\end{array}$ & [148] \\
\hline BPA & $\begin{array}{l}\text { Neonatal } \\
\text { exposure }\end{array}$ & $\begin{array}{l}\text { Blank control group, } \\
\text { negative control group } \\
\text { (corn oil) and BPA } 100 \\
\mu \mathrm{g} / \mathrm{kg} \text { group. }\end{array}$ & ICR mice & $\begin{array}{l}\text { Decreased diameter and the epithelium } \\
\text { thickness of seminiferous epithelium } \\
\text { - Increased lumen in the seminiferous tubules } \\
\text { - Decreased expression and protein level of } \\
\text { Boule mRNA }\end{array}$ & $\begin{array}{l}\text { Neonatal BPA exposure has a long-term } \\
\text { effect on mouse testicular development } \\
\text { and may affect testicular development } \\
\text { by decreasing the expression of Boule } \\
\text { mRNA and protein in testes. }\end{array}$ & [149] \\
\hline
\end{tabular}


Table 5. Cont.

\begin{tabular}{|c|c|c|c|c|c|c|}
\hline Chemical & $\begin{array}{l}\text { Exposure } \\
\text { Window }\end{array}$ & Dose & $\begin{array}{l}\text { Model/Study } \\
\text { Population }\end{array}$ & Effects & Conclusion & Reference \\
\hline BPA & $\begin{array}{l}\text { Gestational } \\
\text { exposure }\end{array}$ & $\begin{array}{l}\text { Pregnant mice were } \\
\text { injected intraperitoneally } \\
\text { daily with sesame oil } \\
\text { vehicle control or } \\
25 \mu \mathrm{g} / \mathrm{kg} \mathrm{BPA}\end{array}$ & CD-1 mice & $\begin{array}{l}\text { - Increased defects in the developing } \\
\text { mammary epithelium } \\
\text { - } \quad \text { Altered Ki67 and } E R \alpha \text { expression }\end{array}$ & $\begin{array}{l}\text { BPA exposure caused increased defects } \\
\text { in the developing mammary epithelium } \\
\text { and altered Ki67 and } E R \alpha \text { expression. }\end{array}$ & [150] \\
\hline BPA & $\begin{array}{l}\text { Adult } \\
\text { exposure }\end{array}$ & $\begin{array}{l}\text { Control and experimental } \\
\text { groups ( } 5 \mathrm{mg} / \mathrm{kg} \mathrm{BPA} \\
\text { daily for } 8 \text { weeks) }\end{array}$ & Albino rats & $\begin{array}{l}\text { - Increased number and size of the acini and } \\
\text { ducts in the mammary gland of treated rats } \\
\text { with hyperplasia of their lining epithelial cells } \\
\text { - Increased collagen content in the connective } \\
\text { tissue stroma separating the ducts } \\
\text { - Increased Ki67 and caspase-3 levels }\end{array}$ & $\begin{array}{l}\text { BPA induced structural changes and } \\
\text { affected the proliferation rate of } \\
\text { mammary glands. }\end{array}$ & [151] \\
\hline BPA & $\begin{array}{l}\text { Adult } \\
\text { exposure }\end{array}$ & $\begin{array}{l}\text { Experiment } 1 \text { : BPA at } \\
\text { doses of } 0,1 \mathrm{mg}, 10 \mathrm{mg} \text {, } \\
100 \mathrm{mg}, 1 \mathrm{mg} \text {, and } \\
10 \mathrm{mg} / \mathrm{kg} \text { every day, } \\
\text { respectively, for } 28 \text { days } \\
\text { Experiment } 2: \text { oral BPA at } \\
\text { doses of } 0,1 \mathrm{mg} \text {, and } \\
10 \mathrm{mg} / \mathrm{kg} \text { Experiment } 3 \text { : } \\
\text { oral BPA at doses of } 0 \text {, } \\
100 \mathrm{mg} \text {, and } 10 \mathrm{mg} / \mathrm{kg}\end{array}$ & CD-1 mice & $\begin{array}{l}\text { - } \quad \text { Downregulaion of } P T E N \text { expression } \\
\text { Accelerated premature activation of } \\
\text { primordial follicles and this effect was partly } \\
\text { reversible by PTEN overexpression }\end{array}$ & $\begin{array}{l}\text { BPA initiates excessive premature } \\
\text { activation of primordial follicles in } \\
\text { themature mouse ovaries via the } \\
\text { PTEN/PI3K / AKT signaling pathway. }\end{array}$ & [152] \\
\hline BPA & $\begin{array}{l}\text { Perinatal } \\
\text { exposure }\end{array}$ & $\begin{array}{l}\mathrm{BPA} 0.05 \mathrm{mg} / \mathrm{kg} \text {, } \\
20 \mathrm{mg} / \mathrm{kg} \text {, or vehicle, } \\
\text { from gestational day } 6 \text { to } \\
\text { lactation day } 21\end{array}$ & Wistar rats & $\begin{array}{l}\text { - Induced alterations in progesterone and } \\
\text { estradiol serum levels, and implantation rate } \\
\text { - Altered levels of claudin- }-1 \text {, claudins }-3 \text {, } \\
\text { claudins }-4 \text {, and claudins }-7 \text { in stromal cells } \\
\text { - Altered levels of ZO-1 in stromal cells }\end{array}$ & $\begin{array}{l}\text { BPA treatment during the perinatal } \\
\text { period perturbs the expression of tight } \\
\text { junction proteins in the uterine } \\
\text { epithelium and reduces the number of } \\
\text { implantation sites. }\end{array}$ & [153] \\
\hline
\end{tabular}


Table 5. Cont.

\begin{tabular}{|c|c|c|c|c|c|c|}
\hline Chemical & $\begin{array}{l}\text { Exposure } \\
\text { Window }\end{array}$ & Dose & $\begin{array}{l}\text { Model/Study } \\
\text { Population }\end{array}$ & Effects & Conclusion & Reference \\
\hline BPA & $\begin{array}{l}\text { Adult } \\
\text { exposure }\end{array}$ & $\begin{array}{l}\text { Oral BPA } 60 \mu \mathrm{g} / \mathrm{kg} \\
\text { dissolved in ethanol, and } \\
\text { suspended in } \\
\text { tocopherol-stripped corn } \\
\text { oil for } 0.1 \% \text { final ethanol } \\
\text { concentration or vehicle } \\
\text { tocopherol-stripped corn } \\
\text { oil }+0.1 \% \text { ethanol }\end{array}$ & C57BL6 mice & $\begin{array}{l}\text { - Increased proliferation, of the } \\
\text { glandular epithelium } \\
\text { - Reduced expression of heart and neural crest } \\
\text { derivatives expressed } 2 \text { (HAND2) } \\
\text { - Increased methylation of a CpG island in the } \\
\text { Hand2 gene promoter }\end{array}$ & $\begin{array}{l}\text { Chronic oral exposure to a low } \\
\text { concentration of BPA during adulthood } \\
\text { impedes transcriptional activation of the } \\
\text { antiproliferative factor HAND2, likely } \\
\text { through an epigenetic mechanism } \\
\text { involving hypermethylation at the } \\
\text { Hand2 promoter. }\end{array}$ & [154] \\
\hline BPA & $\begin{array}{l}\text { Adult } \\
\text { exposure }\end{array}$ & $\begin{array}{l}\text { Control, } 0.05 \mathrm{mg} / \mathrm{kg} / \text { day } \\
\text { of BPA, or } 0.5 \mathrm{mg} / \mathrm{kg} / \text { day } \\
\text { of BPA }\end{array}$ & Piétrain $\times$ Duroc sows & $\begin{array}{l}\text { Increased number of NRG-1-LI positive } \\
\text { nerves in the uterus } \\
\text { Increased changes in neurochemical } \\
\text { characterization of NRG-1-LI nerves in the } \\
\text { uterine wall }\end{array}$ & $\begin{array}{l}\text { NRG-1 in nerves supplying the uterus } \\
\text { may play roles in adaptive and } \\
\text { protective mechanisms under the impact } \\
\text { of BPA. }\end{array}$ & [155] \\
\hline BPA & $\begin{array}{l}\text { Adult } \\
\text { exposure }\end{array}$ & $\begin{array}{l}\text { Median serum BPA } \\
\text { concentrations } 0.19 \text { vs. } \\
0.18 \mathrm{ng} / \mathrm{mL} \text { in healthy and } \\
\text { infertile men, respectively }\end{array}$ & 55 infertile men, in Greece & $\begin{array}{l}\text { - High concentrations of BPA ( }>3 \mathrm{ng} / \mathrm{ml} \text { ) were } \\
\text { observed only in infertile men } \\
\text { A negative correlation was observed between } \\
\text { BPA concentrations and AMH }\end{array}$ & $\begin{array}{l}\text { Very high concentrations of BPA are } \\
\text { associated with azoospermia. }\end{array}$ & [156] \\
\hline BPA & $\begin{array}{l}\text { Adult } \\
\text { exposure }\end{array}$ & $\begin{array}{l}\text { Range of urinary BPA } \\
\text { concentrations from } \\
0.16-11.5 \mathrm{ng} / \mathrm{mL}\end{array}$ & $\begin{array}{l}215 \text { healthy young male } \\
\text { students (18-23 years } \\
\text { old), investigated } \\
\text { between } 2010 \text { and } 2011 \text { in } \\
\text { Southern Spain }\end{array}$ & $\begin{array}{l}\text { Positive association between urinary BPA } \\
\text { concentrations and serum LH levels } \\
\text { Urinary BPA concentration inversely } \\
\text { associated with sperm concentration }\end{array}$ & $\begin{array}{l}\text { BPA exposure may be associated with a } \\
\text { reduction in Leydig cell capacity } \\
\text { (increased LH levels) and decreased } \\
\text { sperm counts in young men. }\end{array}$ & [5] \\
\hline BPA & $\begin{array}{l}\text { Adult } \\
\text { exposure }\end{array}$ & $\begin{array}{l}\text { Medians of unadjusted } \\
\text { BPA concentrations: } 0.32 \\
(0.08-6.86) \mu \mathrm{g} / \mathrm{L}\end{array}$ & $\begin{array}{l}500 \text { men aged } 18-55 \text { years } \\
\text { and having at least one } \\
\text { child, in Guizhou } \\
\text { Province, China, } 2012\end{array}$ & $\begin{array}{l}\text { - Subjects in the highest tertile of } \\
\text { creatinine-adjusted BPA group had lower } \\
\text { sperm concentration than those with } \\
\text { undetected BPA }\end{array}$ & $\begin{array}{l}\text { Exposure to environmental BPA } \\
\text { decreases sperm concentration and } \\
\text { sperm swing characteristics (ALH and } \\
\text { MAD), and increases sperm velocity } \\
\text { ratios (LIN, STR and WOB), which } \\
\text { might mediate further effects on } \\
\text { impaired male fecundity. }\end{array}$ & [157] \\
\hline
\end{tabular}


Table 5. Cont.

\begin{tabular}{|c|c|c|c|c|c|c|}
\hline Chemical & $\begin{array}{l}\text { Exposure } \\
\text { Window }\end{array}$ & Dose & $\begin{array}{l}\text { Model/Study } \\
\text { Population }\end{array}$ & Effects & Conclusion & Reference \\
\hline BPA & $\begin{array}{l}\text { Adult } \\
\text { exposure }\end{array}$ & $\begin{array}{l}\text { BPA median } \\
\text { concentrations of infertile } \\
\text { patients and fertile } \\
\text { controls: } 24.2 \mu \mathrm{g} / \mathrm{L} \text { and } \\
20.9 \mu \mathrm{g} / \mathrm{L} \text {, respectively }\end{array}$ & $\begin{array}{l}50 \text { infertile patients and } \\
50 \text { matched controls in } \\
\text { Upper Egypt }\end{array}$ & $\begin{array}{l}\text { - Total BPA levels were negatively associated } \\
\text { with semen quality and antioxidant levels } \\
\text { Total BPA levels were positively correlated } \\
\text { with DNA damage }\end{array}$ & $\begin{array}{l}\text { BPA levels showed stronger associations } \\
\text { with semen quality parameters, sperm } \\
\text { DNA integrity and oxidative stress in } \\
\text { infertile than fertile men sampled from } \\
\text { Upper Egypt. }\end{array}$ & [158] \\
\hline BPA & $\begin{array}{l}\text { Adult } \\
\text { exposure }\end{array}$ & $\begin{array}{l}\text { BPA concentrations } \\
\text { ranged from }<0.4 \text { to } \\
25.5 \mu \mathrm{g} / \mathrm{l}\end{array}$ & $\begin{array}{l}315 \text { men under } 45 \text { years } \\
\text { of age with normal sperm } \\
\text { concentration in Poland }\end{array}$ & $\begin{array}{l}\text { Positive association between the urinary } \\
\text { concentrations of BPA 25th-50th percentile } \\
\text { and total sperm sex chromosome disomy } \\
\text { - Urinary concentration of BPA associated with } \\
\text { increased total sperm sex } \\
\text { chromosome disomy } \\
\text { - Urinary concentration of BPA associated with } \\
\text { increased percentage of immature sperm and } \\
\text { decreased motility }\end{array}$ & $\begin{array}{l}\text { Exposure to BPA is associated with poor } \\
\text { semen quality. }\end{array}$ & [159] \\
\hline BPA & $\begin{array}{l}\text { Adult } \\
\text { exposure }\end{array}$ & $\begin{array}{l}\text { Urinary BPA } \\
\text { concentrations ranged } \\
\text { from }<0.4 \text { to } 25.5 \mu \mathrm{g} / 1\end{array}$ & $\begin{array}{l}84 \text { women (mean age } 35.6 \\
\text { years) undergoing } 112 \\
\text { IVF cycle in } \\
\text { Massachusetts, US }\end{array}$ & $\begin{array}{l}\text { Urinary BPA concentrations were inversely } \\
\text { associated with the number of oocytes } \\
\text { retrieved and peak estradiol levels }\end{array}$ & $\begin{array}{l}\text { BPA was detected in the majority of } \\
\text { women undergoing IVF, and BPA } \\
\text { urinary concentrations were found to be } \\
\text { inversely associated with the number of } \\
\text { oocytes retrieved per cycle and peak } \\
\text { serum estradiol levels. }\end{array}$ & [160] \\
\hline BPA & $\begin{array}{l}\text { Pubertal } \\
\text { exposure }\end{array}$ & $\begin{array}{l}\text { BPA urinary levels } \\
\text { peripheral precocious } \\
\text { puberty } 8.7 \pm 7.6 \mu \mathrm{g} / \mathrm{g} \\
\text { creatinine; central } \\
\text { precocious puberty } \\
8.0 \pm 9.9 \mu \mathrm{g} / \mathrm{g} \text { creatinine }\end{array}$ & $\begin{array}{l}32 \text { healthy girls (age, } \\
8.5 \pm 0.9 \text { years), } 40 \text { girls } \\
\text { with peripheral } \\
\text { precocious puberty (age, } \\
8.4 \pm 0.7 \text { years), and } 42 \\
\text { girls with central } \\
\text { precocious puberty (age, } \\
8.7 \pm 1.0 \text { years) in Korea }\end{array}$ & $\begin{array}{l}\text { High urinary BPA levels were associated with } \\
\text { increased levels of testosterone, } 17 \beta \text {-estradiol, } \\
\text { and pregnenolone }\end{array}$ & $\begin{array}{l}\text { In girls, BPA exposure is associated with } \\
\text { metabolic changes in steroidogenesis, } \\
\text { but not the early onset of precocious } \\
\text { puberty. }\end{array}$ & [161] \\
\hline
\end{tabular}


Table 5. Cont

\begin{tabular}{|c|c|c|c|c|c|c|}
\hline Chemical & $\begin{array}{l}\text { Exposure } \\
\text { Window }\end{array}$ & Dose & $\begin{array}{l}\text { Model/Study } \\
\text { Population }\end{array}$ & Effects & Conclusion & Reference \\
\hline BPA & $\begin{array}{l}\text { Adult } \\
\text { exposure }\end{array}$ & $\begin{array}{l}\text { The median urinary } \\
\text { concentration of BPA was } \\
1.29 \mathrm{ng} / \mathrm{mL} \text { (interquartile } \\
\text { range: } 0.69 \mathrm{ng} / \mathrm{mL}-2.34 \\
\mathrm{ng} / \mathrm{mL} \text { ) }\end{array}$ & $\begin{array}{l}700 \text { women attempting } \\
\text { pregnancy and followed } \\
\text { for } 12 \text { months or until a } \\
\text { pregnancy occurred in } \\
\text { China from } 2013 \text { to } 2015\end{array}$ & $\begin{array}{l}\text { Urinary concentrations of BPA were } \\
\text { associated with a } 13 \% \text { reduction in } \\
\text { fecundability and a } 23 \% \text { increase in odds } \\
\text { of infertility } \\
\text { Women in the highest quartile of urinary BPA } \\
\text { had a 30\% reduction in fecundability and a } \\
64 \% \text { increase in odds of infertility when } \\
\text { compared to those in the lowest quartile }\end{array}$ & $\begin{array}{l}\text { Preconception concentrations of BPA in } \\
\text { female urine were associated with } \\
\text { decreased fecundability, particularly } \\
\text { among women at older ages. }\end{array}$ & [162] \\
\hline BPA & $\begin{array}{l}\text { Maternal } \\
\text { exposure }\end{array}$ & $\begin{array}{l}\text { Range of BPA serum } \\
\text { levels in patients with } \\
\text { miscarriage patients was } \\
0.0419-4.7900 \text { and in } \\
\text { patients with live birth } \\
\text { cases was } \\
0.0020-1.4390 \mathrm{ng} / \mathrm{mL}\end{array}$ & $\begin{array}{l}115 \text { women included in } \\
\text { the study, there were } 47 \\
\text { live births and } 68 \text { clinical } \\
\text { miscarriages in } \\
\text { California, US }\end{array}$ & $\begin{array}{l}\text { Median conjugated BPA concentrations were } \\
\text { higher in the women who had miscarriages } \\
\text { than in those who had live births } \\
\text { Women with the highest quartile of } \\
\text { conjugated BPA had an increased relative risk } \\
\text { of miscarriage compared with the women in } \\
\text { the lowest quartile }\end{array}$ & $\begin{array}{l}\text { Maternal conjugated BPA is associated } \\
\text { with a higher risk of aneuploid and } \\
\text { euploid miscarriage. }\end{array}$ & [163] \\
\hline BPA & $\begin{array}{l}\text { Maternal } \\
\text { exposure }\end{array}$ & $\begin{array}{l}\text { Serum BPA levels in } \\
\text { patients were } 2.59 \pm 5.23 \\
\mathrm{ng} / \mathrm{mL} \text { and } 0.77 \pm 0.38 \\
\mathrm{ng} / \mathrm{mL} \text { for control women }\end{array}$ & $\begin{array}{l}45 \text { patients with a history } \\
\text { of three or more } \\
\text { consecutive first-trimester } \\
\text { miscarriages and } 32 \\
\text { healthy women with no } \\
\text { history of live birth and } \\
\text { infertility inNagoya City, } \\
\text { Japan between August } \\
2001 \text { and December } 2002\end{array}$ & $\begin{array}{l}\text { High exposure to bisphenol A was associated } \\
\text { with the presence of antinuclear antibodies }\end{array}$ & $\begin{array}{l}\text { Exposure to bisphenol A is associated } \\
\text { with recurrent miscarriage. }\end{array}$ & [164] \\
\hline
\end{tabular}


Table 5. Cont.

\begin{tabular}{|c|c|c|c|c|c|c|}
\hline Chemical & $\begin{array}{l}\text { Exposure } \\
\text { Window }\end{array}$ & Dose & $\begin{array}{l}\text { Model/Study } \\
\text { Population }\end{array}$ & Effects & Conclusion & Reference \\
\hline BPA & $\begin{array}{l}\text { Maternal } \\
\text { exposure }\end{array}$ & $\begin{array}{l}\text { Levels of BPA analytes in } \\
\text { maternal and umbilical } \\
\text { cord plasma ranged from } \\
0.05-34.24 \mathrm{ng} / \mathrm{mL}\end{array}$ & $\begin{array}{l}80 \text { pregnant womenin } \\
\text { Michigan, US }\end{array}$ & $\begin{array}{l}\text { A two-fold increase in first trimester maternal } \\
\text { BPA was associated with } 55 \mathrm{~g} \text { less birth } \\
\text { weight when male and female pregnancies } \\
\text { were combined and } 183 \mathrm{~g} \text { less birth weight } \\
\text { with only female pregnancies } \\
\text { A two-fold increase in maternal term BPA } \\
\text { was associated with an increased gestational } \\
\text { length of } 0.7 \text { days for all pregnancies and } 1.1 \\
\text { days for only female pregnancies }\end{array}$ & $\begin{array}{l}\text { Higher BPA exposure levels during first } \\
\text { trimester and term are associated with } \\
\text { sex-specific reduction in birth weight } \\
\text { and increase in gestational length, } \\
\text { respectively. }\end{array}$ & [165] \\
\hline BPA & $\begin{array}{l}\text { Maternal } \\
\text { exposure }\end{array}$ & $\begin{array}{l}\text { Amniotic fluid BPA } \\
\text { concentrations ranged } \\
\text { from } \leq 0.25 \mathrm{ng} / \mathrm{mL} \text { to }>2.0 \\
\mathrm{ng} / \mathrm{mL}\end{array}$ & $\begin{array}{l}\text { Amniotic fluid samples } \\
\text { were collected from } \\
\text { women with ages ranging } \\
\text { from } 16 \text { to } 45 \text { years that } \\
\text { had healthy singleton } \\
\text { pregnancies with infants } \\
\text { born at term in } \\
\text { Philadelphia, US }\end{array}$ & $\begin{array}{l}\text { - The mean body weight of infants with } \\
\text { amniotic fluid BPA } 0.40-2.0 \mathrm{ng} / \mathrm{mL} \text { was } \\
241.8 \mathrm{~g} \text { less than infants with amniotic fluid } \\
\text { BPA less than the limit of quantification after } \\
\text { controlling for covariates }\end{array}$ & $\begin{array}{l}\text { Low level BPA exposure in utero } \\
\text { decreases body weight. }\end{array}$ & [166] \\
\hline BPA & $\begin{array}{l}\text { Maternal } \\
\text { exposure }\end{array}$ & $\begin{array}{l}\text { Concentration of } \\
\text { bisphenols and } \\
\text { phthalates in urine } \\
\text { ranged from } 0.33-1080.01 \\
\text { ng/mL }\end{array}$ & $\begin{array}{l}1213 \text { pregnant women in } \\
\text { Rotterdam, the } \\
\text { Netherlands }\end{array}$ & $\begin{array}{l}\text { - Higher total bisphenols and bisphenol S were } \\
\text { associated with lower total gestational weight } \\
\text { gain specifically in normal weight women } \\
\text { - Total bisphenol and BPA urine concentrations } \\
\text { were associated with lower mid- to late } \\
\text { pregnancy gestational weight gain }\end{array}$ & $\begin{array}{l}\text { Higher maternal bisphenol urine } \\
\text { concentrations in early pregnancy may } \\
\text { lead to reduced gestational weight in the } \\
\text { second half of pregnancy. }\end{array}$ & [167] \\
\hline BPA & $\begin{array}{l}\text { Maternal } \\
\text { exposure }\end{array}$ & $\begin{array}{l}\text { The median of the } \\
\text { unadjusted urinary BPA } \\
\text { was } 4.70 \mu \mathrm{g} / \mathrm{L} \text { in low birth } \\
\text { weight infants cases, and } \\
2.25 \mu \mathrm{g} / \mathrm{L} \text { in the controls }\end{array}$ & $\begin{array}{l}452 \text { mother-infant pairs in } \\
\text { Wuhan city, China, } \\
\text { during 2012-2014 }\end{array}$ & $\begin{array}{l}\text { Mothers with low birth weight infants had } \\
\text { significantly higher urinary BPA levels than } \\
\text { the control mothers } \\
\text { - Increased risk of low birth weight was } \\
\text { associated with higher maternal urinary } \\
\text { levels of BPA } \\
\text { - The association was more pronounced among } \\
\text { female infants than among male infants }\end{array}$ & $\begin{array}{l}\text { Prenatal exposure to higher levels of } \\
\text { BPA may potentially increase the risk of } \\
\text { delivering low birth weight infants, } \\
\text { especially for female infants. }\end{array}$ & [168] \\
\hline
\end{tabular}


Other studies showed that BPA exposure affected uterine function by impairing implantation and the establishment of pregnancy in mice and rats, caused intra-uterine growth restriction in mouse fetuses, altered steroid hormone signaling in mouse uteri, and impaired the number of nerve fibers in the wall of the porcine uterus $[13,153-155,169]$. Collectively, these studies show that BPA exposure affects the reproductive tract and reduces non-human animal fertility (Table 5).

\subsubsection{Humans}

BPA has been shown to be associated with impaired reproductive function in men and women. For example, in a study in Greece, very high concentrations of plasma BPA were associated with azoospermia in men [156]. Further, in a cross-sectional study with young men, high levels of urinary BPA were positively associated with serum luteinizing hormone (LH) levels and negatively associated with sperm concentration [5]. Other studies show that BPA urinary levels are associated with decreased sperm concentration, reduced semen quality, decreased antioxidant levels, reduced sperm DNA integrity, decreased motility, and an increased percentage of immature sperm [157-159]. Moreover, BPA levels in urine were inversely associated with both the number of oocytes retrieved in women undergoing in vitro fertilization and the serum levels of estradiol [160]. Lee et al. observed associations among high urinary BPA levels and increased serum levels of testosterone, estradiol, and pregnenolone in girls diagnosed with precocious puberty [161]. In a recent study, serum BPA concentrations were higher in women diagnosed with polycystic ovary syndrome compared to women in the healthy groups [170]. Moreover, increased serum BPA concentrations were associated with reduced fecundability among women without preconception folic acid supplementation. Wang et al. also observed decreased fecundability in Chinese women attempting pregnancy with high concentrations of BPA in the urine [162]. Further, studies have shown that high serum and urinary BPA levels were associated with increased miscarriage risk [163,164,171]. In addition, high levels of BPA in maternal blood, urine, or amniotic fluid were associated with decreased gain weight during pregnancy and low birth weight [165-168]. Collectively, these studies indicate that BPA exposure is negatively associated with adverse reproductive function in men and women (Table 5).

Substantial evidence demonstrates that BPA is a reproductive toxicant in non-human animals and humans. For that reason, structural analogues have been used as BPA alternatives, but some of these compounds have been also identified as toxicants [172]. Thus, future research is necessary to elucidate the mechanisms by which BPA analogues act in the reproductive system.

\section{Phthalates}

Phthalates are versatile plasticizers, lubricants, and solvents, which are used in a number of industries. They can be grouped into high and low molecular weight categories based on their chemical functional groups and carbon number. High molecular weight phthalates are commonly found in food storage containers, including single and reusable water bottles, children's toys, PVC products such as construction materials and clothing, and medical equipment such as intravenous tubing and transfusion bags. The high molecular weight phthalates discussed in this review are di (2-ethylhexyl) phthalate (DEHP), benzyl butyl phthalate (BBP), di-isononyl phthalate (DiNP), and di-n-octyl phthalate (DnOP). Low molecular weight phthalates are ubiquitously used in cosmetics and personal care products, pharmaceuticals, and adhesives. The low molecular weight phthalates discussed in this review are diethyl phthalate (DEP), dimethyl phthalate (DMP), dibutyl phthalate (DBP), and diisobutyl phthalate (DiBP).

\subsection{Sources of Exposure to Phthalates}

Since phthalates participate in non-covalent interactions with plastic polymers, they readily leach out, contaminating both the individuals exposed to them and the environment [173]. In comparison, low molecular weight phthalates are more water soluble than long-chain high molecular weight phthalates and thus, they are more likely to accumulate in finished drinking water and drinking 
water sources [174]. Furthermore, phthalates are relatively stable in the environment, which leads to environmental buildup. Even phthalates that do not directly contaminate drinking water sources can enter these sources from buildup in sediment, agricultural soil, and urban soil. Global meta-analyses of phthalates found contamination at concentrations of $0.01-115 \mathrm{mg} / \mathrm{kg}$ in sediment, $0.02-264 \mathrm{mg} / \mathrm{kg}$ in agricultural soils, and $0.01-30.1 \mathrm{mg} / \mathrm{kg}$ in urban soils [173]. Both high and low molecular weight phthalates enter drinking water through two primary routes: (1) phthalates from industrial runoff contaminate drinking water sources such as surface and groundwater and (2) phthalates can leach into our drinking water from plastic food and water storage units such as water bottles.

In 2006, raw drinking water in California was tested for phthalate contamination. DBP $(1.44 \mu \mathrm{g} / \mathrm{L}$ and $8.34 \mu \mathrm{g} / \mathrm{L})$ and DEHP $(2.67-5.94 \mu \mathrm{g} / \mathrm{L})$ were the leading phthalate contaminants followed by DMP $(0.08-0.789 \mu \mathrm{g} / \mathrm{L})$, DEP $(0.899-1.49 \mu \mathrm{g} / \mathrm{L})$, and BBP $(0.053-1.19 \mu \mathrm{g} / \mathrm{L})$ [175]. In a nationwide survey of six phthalates in drinking water sources across China, DEP, DMP, DMP, BBP, DEHP and DnOP were all detected. DBP and DEHP were found most abundantly, with median values of $0.18 \mu \mathrm{g} / \mathrm{L}$ [176]. More recently, DBP concentrations in the Yangtze River in the Delta City of China have exceeded the Chinese surface water standards [177]. In addition to parent phthalate compounds, bioactive phthalate metabolites named phthalate monoesters have recently been identified in drinking water sources from 24 Chinese cities. Monomethyl phthalate (MMP), monoethyl phthalate (MEP), monoisobutyl phthalate (MiBP), mono-n-butyl phthalate (MnBP), and mono-2-ethylhexyl phthalate (MEHP) were detected at mean concentrations of $12.1 \pm 18.0,2.4 \pm 5.8,11.3 \pm 37.2,36.3 \pm 103$, and $9.9 \pm 18.0 \mathrm{ng} / \mathrm{L}$, respectively [178].

Most single-use plastic water bottles are made of polyethylene terephthalate (PET). They are popular around the world due to their convenience and low cost. High and low molecular weight phthalates leach out of PET bottles and into the drinking water. The storage of these bottles at various temperatures can accelerate the leaching of phthalates into the water, increasing exposure levels. Drinking water from the bottles of 10 popular PET brands stored at various temperatures was tested for the presence of phthalates in Beijing, China. DEP, DMP, and DBP were found in all samples at concentrations ranging from 101.97 to $709.87 \mu \mathrm{g} / \mathrm{kg}$. DEP, DMP, DBP, BBP, DOP, and DEHP were detected at levels between 0.18 and $0.71 \mu \mathrm{g} / \mathrm{L}$ in water from bottles stored at room temperature. The concentrations of these same six phthalates increased from 0.19 to $0.98 \mu \mathrm{g} / \mathrm{L}$ when the bottles were stored at outdoor temperatures above $24^{\circ} \mathrm{C}$. DBP was the main phthalate component that increased in response to higher storage temperatures [179]. DEHP was the most commonly detected phthalate in bottled water in Greece, with a median concentration of $350 \mathrm{ng} / \mathrm{L}$. DNP (44 ng/L) and DEP (33 ng/L) were also detected in bottled water, although at lower concentrations than DEHP [180]. DnBP $(0.06-6.5 \mu \mathrm{g} / \mathrm{L})$, DIBP $(0.1-1.89 \mu \mathrm{g} / \mathrm{L})$, and DEHP $(0.02-0.16 \mu \mathrm{g} / \mathrm{L})$ were detected in Portuguese drinking water stored in both PET and glass bottles. DEHP was detected in water from PET bottles at concentrations up to five times higher than water from glass bottles. However, DnBP was higher in the water stored in glass bottles, and it reached an average concentration of $6.5 \mu \mathrm{g} / \mathrm{L}$ [181]. The leaching capacity of various phthalates from drinking containers exposed to sunlight and baby feeders subject to disinfection by boiling, autoclaving, and oven disinfection yielded 10 detectable phthalates and identified that DMP, DMEP, DEP, and DBP had the greatest leaking potential, with average concentrations between 9 and $112.5 \mu \mathrm{g} / \mathrm{L}$.

\subsection{Effects of Phthalates on the Reproductive System}

\subsubsection{Non-Human Animals}

DEHP has been shown to cause early reproductive senescence in male CD-1 mice by impairing testosterone production, reducing sperm quality, and decreasing fertility [6]. DBP has been shown to decrease the numbers of sperm and Sertoli cells in the F1, F2, and F3 generations of male SpragueDawley rats born to exposed females [182]. In utero DEHP exposure has also been shown to delay the onset of puberty in the F3 generation and decrease sperm count, while increasing the frequency of abnormal seminiferous tubules in the F3 and F4 generations of male CD-1 mice [183] (Table 6). 
Table 6. Effects of Phthalates on the Reproductive System.

\begin{tabular}{|c|c|c|c|c|c|c|}
\hline Chemical & $\begin{array}{l}\text { Exposure } \\
\text { Window }\end{array}$ & Dose & $\begin{array}{l}\text { Model/Study } \\
\text { Population }\end{array}$ & Effects & Conclusion & Reference \\
\hline DEHP & $\begin{array}{l}\text { Gestational } \\
\text { exposure }\end{array}$ & $\begin{array}{l}20 \mu \mathrm{g} / \mathrm{kg} / \text { day } \\
200 \mu \mathrm{g} / \mathrm{kg} / \text { day } \\
500 \mathrm{mg} / \mathrm{kg} / \text { day }\end{array}$ & CD-1 mice & $\begin{array}{l}\text { Impaired testosterone } \\
\text { production, reduced sperm } \\
\text { quality, and decreased fertility }\end{array}$ & $\begin{array}{l}\text { Prenatal phthalate exposure } \\
\text { has adverse reproductive } \\
\text { outcomes in male mice. }\end{array}$ & [6] \\
\hline DBP & $\begin{array}{l}\text { Gestational } \\
\text { exposure }\end{array}$ & 500 mg/kg/day & $\begin{array}{l}\text { Sprague-Dawley rats } \\
\text { F1, F2, and F3 } \\
\text { generations }\end{array}$ & $\begin{array}{l}\text { Decreased numbers of sperm } \\
\text { and Sertoli cells }\end{array}$ & $\begin{array}{l}\text { Prenatal phthalate exposure } \\
\text { has adverse reproductive } \\
\text { outcomes in male mice. }\end{array}$ & [182] \\
\hline DEHP & $\begin{array}{l}\text { Gestational } \\
\text { exposure }\end{array}$ & 500 mg/kg/day & $\begin{array}{l}\mathrm{CD}-1 \text { mice } \mathrm{F} 3 \text { and } \mathrm{F} 4 \\
\text { generations }\end{array}$ & - Abnormal seminiferous tubules & $\begin{array}{l}\text { Prenatal phthalate exposure } \\
\text { has adverse reproductive } \\
\text { outcomes in male mice. }\end{array}$ & [183] \\
\hline DEHP & Adult exposure & $1-100 \mathrm{ml} / \mathrm{kg}$ & $\begin{array}{l}\text { Male and female mice } \\
8-10 \text { weeks of age }\end{array}$ & $\begin{array}{l}\text { Females: Reduced incidence of } \\
\text { pregnancy, damage to ovarian } \\
\text { germ cells, fewer and smaller } \\
\text { corpora lutea } \\
\text { - Males: Reduced testicular } \\
\text { weight, atrophy of seminiferous } \\
\text { tubules, chronic inflammation } \\
\text { of testes } \\
\text { Both: elevated activity of } \\
\text { lysosomal enzymes }\end{array}$ & $\begin{array}{l}\text { Prenatal phthalate exposure } \\
\text { has adverse reproductive } \\
\text { outcomes in male mice. }\end{array}$ & [184] \\
\hline MEHP & $\begin{array}{l}\text { Gestational } \\
\text { exposure }\end{array}$ & $\begin{array}{l}100 \mathrm{mg} / \mathrm{kg} \\
500 \mathrm{mg} / \mathrm{kg} \\
1000 \mathrm{mg} / \mathrm{kg}\end{array}$ & Female C57/B16 mice & $\begin{array}{l}\text { Decreased reproductive } \\
\text { lifespan, delayed estrous onset, } \\
\text { prolonged estrus, elevated } \\
\text { serum FSH and estradiol, } \\
\text { altered mRNA expression of } \\
\text { steroidogenic enzymes }\end{array}$ & $\begin{array}{l}\text { Prenatal phthalate exposure } \\
\text { has adverse reproductive } \\
\text { outcomes in male mice. }\end{array}$ & [185] \\
\hline
\end{tabular}


Table 6. Cont

\begin{tabular}{|c|c|c|c|c|c|c|}
\hline Chemical & $\begin{array}{l}\text { Exposure } \\
\text { Window }\end{array}$ & Dose & $\begin{array}{l}\text { Model/Study } \\
\text { Population }\end{array}$ & Effects & Conclusion & Reference \\
\hline DEHP & $\begin{array}{l}\text { Gestational } \\
\text { exposure }\end{array}$ & $\begin{array}{l}0.05 \mathrm{mg} / \mathrm{kg} / \text { day } \\
5 \mathrm{mg} / \mathrm{kg} / \text { day }\end{array}$ & Female mice & $\begin{array}{l}\text { - Reduced oocyte quality, reduced } \\
\text { embryonic } \\
\text { developmental competence } \\
\text { Dysregulation of genes responsible } \\
\text { for ovarian and } \\
\text { embryonic development }\end{array}$ & $\begin{array}{l}\text { In utero exposure to DEHP } \\
\text { has adverse reproductive } \\
\text { outcomes. }\end{array}$ & [186] \\
\hline DEHP & $\begin{array}{l}\text { Gestational } \\
\text { exposure }\end{array}$ & $\begin{array}{l}1 \mathrm{mg} / \mathrm{kg} / \text { day } \\
20 \mathrm{mg} / \mathrm{kg} / \text { day } \\
50 \mathrm{mg} / \mathrm{kg} / \text { day } \\
300 \mathrm{mg} / \mathrm{kg} / \text { day } \\
\text { Gestational day } 14 \\
\text { until birth }\end{array}$ & Female mice F1, F2, F3 & $\begin{array}{l}\text { - F1: Reduced estrogen levels at } \\
\text { proestrous and estrous, decreased } \\
\text { thecal cell layers } \\
\text { - F3: Decreased weights, rates of } \\
\text { pregnancy and increased litter size }\end{array}$ & $\begin{array}{l}\text { The adverse reproductive } \\
\text { outcomes of DEHP are } \\
\text { transgenerational. }\end{array}$ & [187] \\
\hline DEHP & $\begin{array}{l}\text { Gestational } \\
\text { exposure }\end{array}$ & $\begin{array}{l}20 \mu \mathrm{g} / \mathrm{kg} / \text { day } \\
200 \mu \mathrm{g} / \mathrm{kg} / \text { day } \\
500 \mu \mathrm{g} / \mathrm{kg} / \text { day } \\
750 \mathrm{mg} / \mathrm{kg} / \text { day } \\
\text { Gestational day } \\
10.5 \text { until birth }\end{array}$ & Female CD-1 mice & $\begin{array}{l}\text { - } \quad \text { F1: decreased rate of pregnancy } \\
\text { and fertility indices } \\
\text { - } \quad \text { F3: female biased litters, decreased } \\
\text { anogenital distance }\end{array}$ & $\begin{array}{l}\text { The adverse reproductive } \\
\text { outcomes of DEHP are } \\
\text { transgenerational. }\end{array}$ & [188] \\
\hline DEHP & $\begin{array}{l}\text { Postnatal } \\
\text { exposure }\end{array}$ & $\begin{array}{l}20 \mu \mathrm{g} / \mathrm{kg} / \text { day } \\
40 \mu \mathrm{g} / \mathrm{kg} / \text { day }\end{array}$ & Female CD-1 mice & $\begin{array}{l}\text { Decreased expression of } \\
\text { steroidogenic genes, reduced } \\
\text { ovarian concentrations of } \\
\text { progesterone, estradiol, and } \\
\text { androstenedione, reduced LH in } \\
\text { serum, altered structure of } \\
\text { theca cells }\end{array}$ & $\begin{array}{l}\text { DEHP exposure shortly after } \\
\text { birth has adverse } \\
\text { reproductive outcomes. }\end{array}$ & [189] \\
\hline
\end{tabular}


Table 6. Cont.

\begin{tabular}{|c|c|c|c|c|c|c|}
\hline Chemical & $\begin{array}{l}\text { Exposure } \\
\text { Window }\end{array}$ & Dose & $\begin{array}{l}\text { Model/Study } \\
\text { Population }\end{array}$ & Effects & Conclusion & Reference \\
\hline $\begin{array}{l}\text { Urinary metabolites } \\
\text { of DiNP }\end{array}$ & $\begin{array}{l}\text { Gestational } \\
\text { exposure }\end{array}$ & $\begin{array}{l}\text { average } 67.74 \\
\mathrm{ng} / \mathrm{ml}\end{array}$ & $\begin{array}{l}197 \text { infant males from } \\
\text { Sweden, } 21 \text { months of } \\
\text { age }\end{array}$ & - $\quad$ Reduced anogenital distance & $\begin{array}{l}\text { DiNP is not a suitable } \\
\text { replacement for DEHP } \\
\text { because it is associated with } \\
\text { adverse reproductive } \\
\text { outcomes. }\end{array}$ & [190] \\
\hline $\begin{array}{l}\text { Urinary metabolites } \\
\text { of DEHP }\end{array}$ & $\begin{array}{l}\text { Gestational } \\
\text { exposure }\end{array}$ & $1.93-71.7 \mathrm{ng} / \mathrm{ml}$ & $\begin{array}{l}366 \text { boys from US } \\
\text { examined shortly after } \\
\text { birth }\end{array}$ & - $\quad$ Reduced anogenital distance & $\begin{array}{l}\text { Environmental exposure to } \\
\text { DEHP is associated with } \\
\text { adverse male genital } \\
\text { development. }\end{array}$ & [191] \\
\hline $\begin{array}{l}\text { Urinary phthalate } \\
\text { metabolites }\end{array}$ & Adult exposure & $0.54-18.5 \mathrm{ng} / \mathrm{ml}$ & 501 adult males in US & $\begin{array}{l}\text { - Lower total sperm counts and } \\
\text { concentrations, larger sperm head } \\
\text { sizes, lower and higher } \\
\text { sperm motility }\end{array}$ & $\begin{array}{l}\text { Phthalate exposure is } \\
\text { associated with adverse } \\
\text { reproductive outcomes in } \\
\text { adult males. }\end{array}$ & [192] \\
\hline $\begin{array}{l}\text { Serum DEHP and } \\
\text { DiNP metabolites }\end{array}$ & Adult exposure & $0.01-1.7 \mathrm{ng} / \mathrm{ml}$ & $\begin{array}{l}589 \text { adult males from } \\
\text { Greenland, Poland, and } \\
\text { Ukraine }\end{array}$ & $\begin{array}{l}\text { Decreased testosterone, decreased } \\
\text { semen volume and total } \\
\text { sperm count }\end{array}$ & $\begin{array}{l}\text { Consistent findings of the } \\
\text { anti-adrenergic effects of } \\
\text { phthalates. }\end{array}$ & [193] \\
\hline $\begin{array}{l}\text { DEHP and DiNP in } \\
\text { maternal sera }\end{array}$ & $\begin{array}{l}\text { Gestational } \\
\text { exposure }\end{array}$ & $0.026-5.2 \mathrm{ng} / \mathrm{ml}$ & $\begin{array}{l}112 \text { adolescent males in } \\
\text { Sweden }\end{array}$ & $\begin{array}{l}\text { DiNP: Decreased testicular volume } \\
\text { and semen volume, higher levels of } \\
\text { follicle stimulating hormone } \\
\text { - DEHP: decreased semen volume }\end{array}$ & $\begin{array}{l}\text { DEHP and DiNP exposure is } \\
\text { associated with adverse } \\
\text { reproductive outcomes in } \\
\text { adolescent males. }\end{array}$ & [194] \\
\hline $\begin{array}{l}\text { Urinary DEHP, } \\
\text { DBzP, and DBP } \\
\text { metabolites }\end{array}$ & Adult exposure & $4.5-83.4 \mu \mathrm{g} / \mathrm{l}$ & 269 men in US & $\begin{array}{l}\text { Decreased sperm motility, } \\
\text { decreased testosterone levels, } \\
\text { increased sperm DNA damage and } \\
\text { sperm aneuploidy }\end{array}$ & $\begin{array}{l}\text { Phthalate exposure is } \\
\text { associated with adverse } \\
\text { reproductive outcomes in } \\
\text { adult males. }\end{array}$ & [195] \\
\hline
\end{tabular}


Table 6. Cont

\begin{tabular}{|c|c|c|c|c|c|c|}
\hline Chemical & $\begin{array}{l}\text { Exposure } \\
\text { Window }\end{array}$ & Dose & $\begin{array}{l}\text { Model/Study } \\
\text { Population }\end{array}$ & Effects & Conclusion & Reference \\
\hline $\begin{array}{l}\text { Urinary DiBP, } \\
\text { DEHP, DBP, and } \\
\text { DBzP metabolites }\end{array}$ & Adult exposure & $0.2-78.7 \mathrm{ng} / \mathrm{ml}$ & 1066 adult Chinese men & $\begin{array}{l}\text { - Decreased serum testosterone and } \\
\text { luteinizing hormone } \\
\text { Decreased Leydig cell production } \\
\text { of INSL3 }\end{array}$ & $\begin{array}{l}\text { Phthalates are associated } \\
\text { with disrupted } \\
\text { steroidogenesis in adult } \\
\text { males. }\end{array}$ & [196] \\
\hline $\begin{array}{l}\text { Urinary DBP } \\
\text { metabolites }\end{array}$ & Adult exposure & $\begin{array}{l}\text { Average 17-7 } \\
\mathrm{ng} / \mathrm{ml}\end{array}$ & 463 adult males in US & $\begin{array}{l}\text { - Decreased sperm concentration } \\
\text { and motility }\end{array}$ & $\begin{array}{l}\text { DBP is associated with } \\
\text { altered semen quality in } \\
\text { adult males. }\end{array}$ & [197] \\
\hline $\begin{array}{l}\text { Urinary metabolites } \\
\text { of DBzP }\end{array}$ & Adult exposure & $\begin{array}{l}\text { Average } 11.13 \\
\mathrm{ng} / \mathrm{ml}\end{array}$ & 420 adult males in US & $\begin{array}{l}\text { - Decreased sperm concentration } \\
\text { and motility }\end{array}$ & $\begin{array}{l}\text { DbzP alters semen quality on } \\
\text { adult males. }\end{array}$ & [198] \\
\hline $\begin{array}{l}\text { Urinary metabolites } \\
\text { of DEHP and DBzP }\end{array}$ & Adult exposure & $0.9-5.2 \mathrm{ng} / \mathrm{ml}$ & $\begin{array}{l}176 \text { Taiwanese adult } \\
\text { males }\end{array}$ & $\begin{array}{l}\text { Decreased serum testosterone, } \\
\text { serum inhibin B, and Leydig cell } \\
\text { production of INSL3 }\end{array}$ & $\begin{array}{l}\text { Non-occupational exposure } \\
\text { to DEHP and DBzP is } \\
\text { associated with adverse } \\
\text { effects on testicular and } \\
\text { Leydig cell function. }\end{array}$ & [199] \\
\hline $\begin{array}{l}\text { Maternal urine } \\
\text { concentrations of } \\
\text { DBzP and DEP }\end{array}$ & $\begin{array}{l}\text { Gestational } \\
\text { exposure }\end{array}$ & $4.1-114 \mu \mathrm{g} / \mathrm{l}$ & $\begin{array}{l}116 \text { adolescent females } \\
\text { in Mexic }\end{array}$ & - Increased testosterone levels & $\begin{array}{l}\text { In utero phthalate exposure } \\
\text { is associated with increased } \\
\text { testosterone levels in } \\
\text { adolescent females. }\end{array}$ & [200] \\
\hline $\begin{array}{l}\text { Maternal DEHP } \\
\text { urine } \\
\text { concentrations }\end{array}$ & $\begin{array}{l}\text { Gestational } \\
\text { exposure }\end{array}$ & $0.04-0.08 \mu \mathrm{g} / \mathrm{l}$ & $\begin{array}{l}131 \text { children } 8 \text { and } 11 \\
\text { years old in Taiwan }\end{array}$ & - $\quad$ Reduced uterus size & $\begin{array}{l}\text { Phthalate exposure is } \\
\text { associated with negative } \\
\text { pubertal development } \\
\text { characteristics in female } \\
\text { children. }\end{array}$ & [201] \\
\hline Urine metabolites & Adult exposure & $2.5-56.2 \mathrm{ng} / \mathrm{ml}$ & $\begin{array}{l}195 \text { midlife women } \\
45-54 \text { years of age in US }\end{array}$ & $\begin{array}{l}\text { - Increases risk and frequency of } \\
\text { hot flashes }\end{array}$ & $\begin{array}{l}\text { Phthalate exposure is } \\
\text { associated with adverse } \\
\text { health outcomes in midlife } \\
\text { women. }\end{array}$ & [202] \\
\hline
\end{tabular}


In laboratory animal studies, phthalate exposure has been associated with a decline in female reproductive health. Experimental data from laboratory animals show that phthalate exposure is associated with increased resorptions and decreased pregnancy, implantations, and fetal weights of offspring [184,203]. Female mice exposed to MEHP in utero (corn oil, 100, 500, or $1000 \mathrm{mg} / \mathrm{kg}$ of MEHP) exhibited premature reproductive senescence compared to female mice that received only corn oil [185]. F1, F2, and F3 female mice exposed to DEHP in utero $(0,0.05,5 \mathrm{mg} / \mathrm{kg} / \mathrm{day}$ of DEHP) had reduced oocyte quality and reduced embryonic developmental competence compared to non-exposed female mice. Genes responsible for ovarian and embryonic development were also dysregulated in exposed mice [186]. In utero exposure to DEHP resulted in F1 female offspring with reduced estrogen levels at proestrus, increased FSH levels at both proestrus and estrus, and significantly decreased thecal cell layers compared to control mice. The F3 generation of females from this same study had decreased weights overall, decreased rates of pregnancy, and increased litter size compared to control [187]. In another study on the transgenerational effects of DEHP exposure, the onset of puberty was accelerated and estrous cyclicity was disrupted in all three generations of female mice. DEHP exposure decreased the rate of pregnancy and fertility indices in the F1 generation. DEHP exposure also increased female-biased litters and decreased anogenital distance in the F3 generation compared to control [188] (Table 6).

DEHP exposure also accelerated folliculogenesis in adult mice orally exposed to DEHP as well as its metabolite MEHP. Following DEHP exposure, the mice had decreased primordial follicle numbers and increased primary, preantral, or antral follicle numbers compared to non-exposed mice [185,204]. DEHP exposure also has been associated with the transgenerational dysregulation of folliculogenesis in female mice. F1 female mice exposed to DEHP in utero had decreased antral follicle numbers at PND 21, and by PND 60, they had decreased primary and preantral follicle numbers compared to control. The exposed females had significantly fewer germ cells as well as accelerated folliculogenesis compared to control [188].

In male laboratory animals, phthalates interfere with sex hormone steroidogenesis in reproductive organs via alterations in steroidogenic gene transcription [205]. HSD3B, the steroidogenic enzyme that catalyzes the conversion of $3 \beta$-hydroxysteroids into 3-keto-steroids, has been identified as a phthalate target in testicular tissue [206] (Table 6).

Parental phthalate compounds and their bioactive monoester metabolites have also been found to interfere with female sex hormone steroidogenesis in female reproductive tissues via transcriptional dysregulation. Female mice administered DEHP at 5, 10, and 15 days postpartum had a significant decrease in the expression of genes responsible for androgen synthesis in the theca cells [189]. These genes included luteinizing hormone/choriogonadotropin receptor (Lhcgr), Cyp17a1, Star, and low-density lipoprotein receptor $(L d l r)$. Ovaries collected from treated mice had significantly decreased concentrations of progesterone, 17beta-estradiol, and androstenedione in their ovaries and reduced LH in serum compared to mice that did not receive the treatment. The thecal nuclear envelope was also deformed in the follicles of exposed mice compared to control [189]. In a transgenerational study of DEHP exposures, F1 generation female mice prenatally exposed to DEHP had significantly decreased serum testosterone levels and increased serum 17beta-estradiol levels compared to the F1 generation of non-treated mice. The F2 generation from this same study had significantly decreased serum progesterone levels compared to the F2 generation of non-treated mice [188] (Table 6).

\subsubsection{Humans}

Phthalates are recognized as reproductive toxicants with endocrine disrupting capabilities in both males and females. Epidemiological studies have identified associations between maternal urine phthalate and phthalate metabolite levels and anogenital distance in boys. Although DEHP and DBP have strong associations with reduced anogenital distance in boys, the metabolites of DiNP, which is a popular DEHP replacement, have moderate associations with reduced anogenital distance $[190,191,207]$. Inverse associations have been reported between urinary concentrations of 
DEHP and DiNP metabolites and sperm concentration, sperm motility, and testosterone levels [192-196]. DBP and BBP urinary metabolites also have inverse associations with sperm concentration and sperm motility [176,192,194,197,198]. Data from the National Health and Nutrition Examination Survey (NHANES) 2011-2012 in the US yielded inverse associations between increasing DiBP metabolite concentrations in urinary phthalates and decreased testosterone [208]. Similar associations were found in a study of infertile men in Taiwan and in fertile and infertile Chinese men [196,199]. Increased DEHP exposure also has been associated with the increased apoptosis of sperm cells and the increased generation of ROS in sperm cells, whereas DEHP, DBP, and BBP have all been associated with increased sperm aneuploidy [195,209-211] (Table 6).

In utero exposure to MEP and MBzP was associated with increased testosterone levels in girls aged 8-13 in a Mexico City birth cohort [200]. Urinary levels of MEHP and MBzP in 8-year-old girls from Taiwan were positively associated with increased serum progesterone levels, and urinary levels of MBzP and MBP were positively associated with increased serum FSH levels [201]. Chronic occupational phthalate exposure in women has been associated with decreased pregnancy rates and increased miscarriage rates [212]. Phthalate exposure also has been associated with complications including anemia, toxemia, and preeclampsia in pregnant women [213]. In a study of midlife women, urinary phthalate metabolite levels were associated with increased risk of ever experiencing hot flashes, having had hot flashes within 30 days of sample collection, and more frequent hot flashes [202]. Collectively, these data show that phthalate exposure is associated with adverse reproductive outcomes throughout a woman's lifetime (Table 6).

Since different types of phthalates are used by the industry and they are relatively stable in the environment, future studies should focus on the effects of exposure to mixtures of phthalates. These mixtures should represent the environmental relevance of phthalates specific to a given area; thus, it may be possible to elucidate if there are synergistic effects through different phthalates exposure.

\section{Pesticides}

Prior to the 1940s, elements such as arsenic, mercury, copper, and lead were used in pest management. Due to low water solubility, their accumulation in water was not a concern. Synthetic organic pesticides were introduced during World War II, and since then, the United States Geological Survey (USGS) estimates that 1 billion pounds of pesticides are applied annually to agricultural land, non-crop land, and urban areas in the United States. The use of these synthetic organic compounds has allowed the US to become the largest producer of food in the world and kept lethal vector-borne diseases such as malaria at bay. However, these accomplishments may have come at a significant cost to human health. Drinking water, which is sourced from either groundwater or surface water, is a potent vehicle of exposure to pesticides for both humans and non-human animals. The Netherlands National Institute of Public Health and Environmental Protection concluded that "groundwater is threatened by pesticides in all European states" [214]. Groundwater is especially vulnerable to persistent pesticide contamination because, in contrast to flowing bodies of water, it remains still. Pesticide contamination of these sources, in addition to the intentional application of pesticides for water disinfection, results in chronic exposure to nontarget species and a significant risk of adverse reproductive health outcomes.

\subsection{Sources of Exposure to Pesticides}

Pesticides are intentionally applied to various water systems to combat disease-causing and intrusive organisms. They are added to waterways such as canals, rivers, lakes, and streams to control mosquitoes, weeds, and invasive fish. Disinfectant pesticides are used in water treatment plants to remove bacterial and viral contamination from drinking water. They are also applied to water used in large-scale irrigation systems, especially in humid and tropical environments. This is done to protect crops from infestations, as well as humans from contracting vector-borne diseases such as malaria. A larger proportion of pesticide contamination in water systems is not due to intentional application. According to the USEPA, pesticides applied to farms, gardens, and lawns run off into both ground and 
surface water systems that feed drinking water supplies in both agricultural and urban settings [215]. Furthermore, the likelihood of a pesticide reaching drinking water is significantly greater when it is spilled, dumped, or misused in comparison to labeled uses. Point sources of pesticide contamination include pesticide manufacturing plants, mixing-and-loading facilities, spills, waste disposal sites, sewage treatment plants, and wastewater recharge facilities such as wells and basins. During the recharge of groundwater, pesticides can seep into and through the soil ending up in aquifers. Nonpoint sources of pesticide contamination in water are the dominant source of pesticides found in both ground and drinking water because they are diffuse and widely dispersed. They include runoff to streams from agricultural and urban land, seepage to groundwater in areas where pesticides are heavily used, leaching out of paint on ships, and illegal disposal by homeowners down the drain. When rain falls on a treated area, it can carry pesticides to surface water sources very far from their point of application. Some pesticides are even capable of moving in the air from their point of application to very distant surface water reservoirs. Atrazine and two of its metabolites were detected in $50 \%$ of precipitation and $23 \%$ of particulate phase atmospheric samples taken from Lake Michigan, US. Furthermore, the atrazine concentrations in the precipitation were not reflective of local land use, insinuating long-range transport through the atmosphere [216].

Pesticides and their metabolites have been detected in drinking water sources across the world. In some cases, their levels exceed the regulatory limits of their respective countries. Atrazine, along with its metabolite desethlatrazine, and simazine were the most frequently detected pesticides above regulatory levels across Europe [217]. Acetochlor was first registered for use in the US in 1994. By 1995, it was detected in multiple sources groundwater around the US, exemplifying how rapidly these chemicals can accumulate in aqueous environments [218]. Pesticides remain in drinking water sources for a considerable time, whether they are applied intentionally or by runoff. This is, in part, due to their chemical properties such as adsorption and solubility. For example, atrazine has low adsorption into soil particles and readily leaches into water. Compared to other herbicides, atrazine has relatively higher solubility [216], making it an ideal candidate for accumulation in drinking water sources. Neonicotinoids, a relatively new family of insecticides, are synthetic nicotine derivates as well as very small and water-soluble compounds [219]. In turn, this leads to neonicotinoids having high leaching and runoff potential [220]. According to the manufacturer, only $5 \%$ of applied imidacloprid, a widely popular neonicotinoid, is spread throughout the crop, and the rest dissipates into the environment [221]. The chemical characteristics and evidence of environmental runoff make neonicotinoids ideal candidates for persistence in drinking water sources [220]. Less soluble pesticides such as dichlorodiphenyltrichloroethane (DDT) and chlordane can adhere to sediment and can consequently persist in waterways for years [222]. Although DDT was banned in the US and many other countries around the world in the early 1970s, DDT and its metabolites are still being detected in drinking water sources globally $[223,224]$.

Herbicides are the greatest offenders of pesticide contamination in drinking water sources in the United States, Europe, and Asia [225]. Researchers and government agencies alike have detected levels of popular herbicides in finished drinking water and in drinking water sources. Namely, atrazine, simazine, metolachlor, and acetochlor are the most commonly detected herbicides in drinking water and drinking water sources.

After herbicides, insecticides are the second most commonly detected pesticide contaminant in drinking water and drinking water sources. Appreciable concentrations of neonicotinoid insecticides, as well as their organophosphate predecessors have been detected in many countries around the world. Organophosphates are recognized as the most acutely toxic family of pesticides to nontarget species, including humans [226]. They can be transported in water long distances from their source of application to surface and groundwater reservoirs. They have been detected in snow, fog, and rainwater $[227,228]$. Furthermore, their primary route of groundwater degradation is hydrolysis, meaning that water contaminated with organophosphate parent compounds is also likely contaminated with hydrolytic metabolites, some of which are even more toxic than their associated parent compounds $[229,230]$. 
Prechlorination is used by all water treatment facilities for water disinfection and odor control. The prechlorination of organophosphates in water significantly increases the concentration of transformed oxons as the primary byproduct of organophosphate oxidation in finished drinking water. The organophosphate oxons are more toxic than their parent compounds, and they are more water soluble, making them even more difficult to remove from the finished drinking water. The organophosphate insecticides most commonly detected in drinking water and drinking water sources are diazinon, chlorpyriphos, and malathion. Diazinon and malathion were detected in Ethiopian drinking water from wells, springs, and tap at concentrations ranging from 1.6 to $5.7 \mu \mathrm{g} / \mathrm{L}$ and 7.3 to 14 $\mu \mathrm{g} / \mathrm{L}$, respectively [231]. Chlorpyriphos ethyl, a chlorpyriphos metabolite, was the most frequently detected insecticide in surface water in Greece, and its average concentration $(0.031 \mu \mathrm{g} / \mathrm{L})$ exceeds the EU environmental quality standard [232]. Malathion was detected in $25 \%$ of drinking water aqueducts in Venezuela $(2.03 \mu \mathrm{g} / \mathrm{L})$. Diazinon was found at levels as high as $26.31 \mu \mathrm{g} / \mathrm{L}$ in these Venezuelan aqueducts. Although these levels are not beyond the Venezuelan limits, they far exceed US and EU EPA levels [233]. In the US, malathion was reported at levels up to $0.18 \mu \mathrm{g} / \mathrm{L}$ in surface water [234].

\subsection{Effects of Atrazine on the Reproductive System}

Atrazine is the most common surface and groundwater herbicide contaminant worldwide. It was detected in $84 \%$ of drinking water samples in Croatia $(5-68 \mathrm{ng} / \mathrm{L})$, and in $74.1 \%$ of drinking water sources in the Guangxi province of China $[235,236]$. Surface and tap water from Northern Italy also is contaminated with atrazine $(5 \mathrm{ng} / \mathrm{L})$ and atrazine-desethyl, which is an atrazine metabolite (11 $\mathrm{ng} / \mathrm{L}$ ) [237]. Atrazine has been detected ubiquitously in Lake Michigan, US open water samples, atmospheric samples, and in 11 tributaries that flow into the lake [216].

\subsubsection{Non-Human Animals}

Atrazine has been shown to cause reproductive toxicity in animal models. Song et al. identified numerous toxic effects of atrazine on the reproductive system of male rats, including irregular and disordered arrangement of seminiferous epithelium, decreased numbers of spermatozoa, increased numbers of abnomal spermatozoa, decreased levels of total antioxidant capacity, decreased serum levels of testosterone and inhibin-B, and increased serum levels of FSH and LH [238]. Female rats exposed to atrazine were found to have significantly delayed vaginal opening, reduced ovary, uterine, and pubertal body weights, and dysregulated estrous cycles with extended periods of diestrous [239,240] (Table 7). 
Table 7. Effects of Pesticides on the Reproductive System.

\begin{tabular}{|c|c|c|c|c|c|c|}
\hline Chemical & $\begin{array}{l}\text { Exposure } \\
\text { Window }\end{array}$ & Dose & $\begin{array}{l}\text { Model/Study } \\
\text { Population }\end{array}$ & Effects & Conclusion & Reference \\
\hline Atrazine & 30 days & $\begin{array}{l}38.5 \mathrm{mg} / \mathrm{kg} / \text { day } \\
77 \mathrm{mg} / \mathrm{kg} / \text { day } \\
154 \mathrm{mg} / \mathrm{kg} / \text { day }\end{array}$ & $\begin{array}{l}\text { Sprague-Dawley } \\
\text { male rats }\end{array}$ & $\begin{array}{l}\text { - Irregular and disordered arrangement of } \\
\text { seminiferous epithelium } \\
\text { - Decreased spermatozoa number, } \\
\text { increased spermatozoa abnormalities } \\
\text { - Decreased serum testosterone and } \\
\text { inhibin B, increased serum FSH and LH }\end{array}$ & $\begin{array}{l}\text { Atrazine exposure results in } \\
\text { adverse reproductive } \\
\text { outcomes in male rats. }\end{array}$ & [238] \\
\hline Atrazine & $\begin{array}{l}\text { Postnatal day } 22 \\
\text { to } 41\end{array}$ & $\begin{array}{l}12.5 \mathrm{mg} / \mathrm{kg} / \text { day } \\
25 \mathrm{mg} / \mathrm{kg} / \text { day } \\
50 \mathrm{mg} / \mathrm{kg} / \text { day } \\
100 \mathrm{mg} / \mathrm{kg} / \text { day } \\
200 \mathrm{mg} / \mathrm{kg} / \text { day }\end{array}$ & Wistar female rats & $\begin{array}{l}\text { - Delayed onset of puberty and altered } \\
\text { estrous cyclicity }\end{array}$ & $\begin{array}{l}\text { Postnatal atrazine exposure } \\
\text { delays onset of puberty in } \\
\text { female rats. }\end{array}$ & [239] \\
\hline Simazine & Maternal & $5-500 \mu \mathrm{g} / \mathrm{kg}$ & $\begin{array}{l}\text { Female offspring } \\
\text { mice }\end{array}$ & $\begin{array}{l}\text { - } \quad \text { Shortened anogenital distance } \\
\text { - } \quad \text { Decreased ovarian and uterine weights } \\
\text { - } \quad \text { Increased apoptotic granulosa cells }\end{array}$ & $\begin{array}{l}\text { Maternal exposure to } \\
\text { simazine impairs } \\
\text { reproductive development of } \\
\text { female offspring. }\end{array}$ & [241] \\
\hline Simazine & $\begin{array}{l}21 \text { days and } 41 \\
\text { days starting on } \\
\text { post-natal day } 22\end{array}$ & $\begin{array}{l}12.5 \mathrm{mg} / \mathrm{kg} / \text { day } \\
25 \mathrm{mg} / \mathrm{kg} / \text { day } \\
50 \mathrm{mg} / \mathrm{kg} / \text { day } \\
100 \mathrm{mg} / \mathrm{kg} / \text { day }\end{array}$ & Wistar female rats & $\begin{array}{l}\text { Delayed vaginal opening, decreased } \\
\text { number of cycles, day of first estrus } \\
\text { delayed, decreased serum prolactin }\end{array}$ & $\begin{array}{l}\text { Simazine delays onset of } \\
\text { puberty. }\end{array}$ & [242] \\
\hline Simazine & $\begin{array}{l}\text { Maternal during } \\
\text { gestation and } \\
\text { lactation }\end{array}$ & $\begin{array}{l}5 \mu \mathrm{g} / \mathrm{kg} \\
50 \mu \mathrm{g} / \mathrm{kg} \\
500 \mu \mathrm{g} / \mathrm{kg}\end{array}$ & $\begin{array}{l}\text { Male offspring } \\
\text { mice }\end{array}$ & $\begin{array}{ll}\text { - } & \text { Decreased testicular and } \\
\text { epididymal weight } \\
\text { - } & \text { Increased testicular apoptosis } \\
\text { - } & \text { Decreased sperm concentrations }\end{array}$ & $\begin{array}{l}\text { Maternal exposure to } \\
\text { simazine has adverse } \\
\text { reproductive outcomes in } \\
\text { male offspring. }\end{array}$ & [243] \\
\hline
\end{tabular}


Table 7. Cont.

\begin{tabular}{|c|c|c|c|c|c|c|}
\hline Chemical & $\begin{array}{l}\text { Exposure } \\
\text { Window }\end{array}$ & Dose & $\begin{array}{l}\text { Model/Study } \\
\text { Population }\end{array}$ & Effects & Conclusion & Reference \\
\hline Metolachlor & $\begin{array}{l}\text { Postnatal day } 23 \\
\text { to } 53\end{array}$ & $\begin{array}{l}5 \mathrm{mg} / \mathrm{kg} / \text { day } \\
50 \mathrm{mg} / \mathrm{kg} / \text { day }\end{array}$ & Wistar male rats & $\begin{array}{l}\text { - Increased serum testosterone, estradiol } \\
\text { and FSH } \\
\text { - Higher amount of fluid in seminal } \\
\text { vesicles, precocious puberty, and changes } \\
\text { in seminiferous epithelial morphology }\end{array}$ & $\begin{array}{l}\text { Prepubertal exposure to } \\
\text { metolachlor is associated } \\
\text { with adverse reproductive } \\
\text { outcomes in male rats. }\end{array}$ & [244] \\
\hline Acetochlor & 30 days & $\begin{array}{l}250 \mathrm{mg} / \mathrm{kg} / \text { day } \\
500 \mathrm{mg} / \mathrm{kg} / \text { day } \\
1000 \mathrm{mg} / \mathrm{kg} / \text { day }\end{array}$ & $\begin{array}{l}\text { Adult C57/BL6 } \\
\text { male mice }\end{array}$ & $\begin{array}{l}\text { Increased markers of oxidative stress, } \\
\text { degeneration of testicular tissue } \\
\text { Elevated apoptosis, elevated expression } \\
\text { of apoptotic proteins }\end{array}$ & $\begin{array}{l}\text { Acetochlor can induce } \\
\text { reproductive toxicity in } \\
\text { subacutely exposed mice. }\end{array}$ & [245] \\
\hline Acetochlor & $\begin{array}{l}\text { Postnatal day } 4 \text { to } \\
7\end{array}$ & $\begin{array}{l}7.68 \mathrm{mg} / \mathrm{kg} / \text { day } \\
15.36 \mathrm{mg} / \mathrm{kg} / \text { day }\end{array}$ & Wistar female rats & $\begin{array}{l}\text { Acceleration of vaginal patency, irregular } \\
\text { cycled, accumulation of uterine nuclear } \\
\text { estrogen receptors }\end{array}$ & $\begin{array}{l}\text { Neonatal exposure to } \\
\text { acetochlor alters pubertal } \\
\text { development in female rats. }\end{array}$ & [246] \\
\hline Malathion & 50 days & $\begin{array}{l}33.75 \mathrm{mg} / \mathrm{kg} \\
54 \mathrm{mg} / \mathrm{kg} \\
108 \mathrm{mg} / \mathrm{kg}\end{array}$ & Wistar male rats & $\begin{array}{l}\text { Lower testis weights, sperm motility, } \\
\text { higher sperm malformation rates } \\
\text { Higher spermatogenic cell apoptosis } \\
\text { rates, higher Bax expression, lower } B c l-2 \\
\text { expression, damage to } \\
\text { seminiferous tubules }\end{array}$ & $\begin{array}{l}\text { Exposure to malathion has a } \\
\text { negative effect on } \\
\text { reproductive health of male } \\
\text { rats. }\end{array}$ & [247] \\
\hline Chlorpyriphos & 45 days & $37 \mathrm{mg} / \mathrm{kg} /$ day & Male rats & $\begin{array}{l}\text { Deceases in sperm counts, viability, and } \\
\text { motility, increased sperm DNA damage, } \\
\text { Increased arrested spermatogenesis, } \\
\text { decreased Leydig cell number, negative } \\
\text { tubular differentiation and } \\
\text { repopulation indices }\end{array}$ & $\begin{array}{l}\text { Exposure to chlorpyriphos } \\
\text { has a negative effect on the } \\
\text { reproductive health of male } \\
\text { rats. }\end{array}$ & [248] \\
\hline
\end{tabular}


Table 7. Cont.

\begin{tabular}{|c|c|c|c|c|c|c|}
\hline Chemical & $\begin{array}{l}\text { Exposure } \\
\text { Window }\end{array}$ & Dose & $\begin{array}{l}\text { Model/Study } \\
\text { Population }\end{array}$ & Effects & Conclusion & Reference \\
\hline Chlorpyriphos & 90 days & $\begin{array}{l}2.7 \mathrm{mg} / \mathrm{kg} \\
5.4 \mathrm{mg} / \mathrm{kg} \\
12.8 \mathrm{mg} / \mathrm{kg}\end{array}$ & Male rats & $\begin{array}{l}\text { - Reduced testicular sperm counts, sperm } \\
\text { motility, increased rates of } \\
\text { sperm malformation } \\
\text { Degenerative changes in seminiferous } \\
\text { tubules, increased FSH, } \\
\text { decreased testosterone, }\end{array}$ & $\begin{array}{l}\text { Chlorpyriphos has adverse } \\
\text { effects on the male } \\
\text { reproductive system. }\end{array}$ & [249] \\
\hline Imidacloprid & 90 days & $\begin{array}{l}0.5 \mathrm{mg} / \mathrm{kg} / \text { day } \\
2 \mathrm{mg} / \mathrm{kg} / \text { day } \\
8 \mathrm{mg} / \mathrm{kg} / \text { day }\end{array}$ & Male rats & 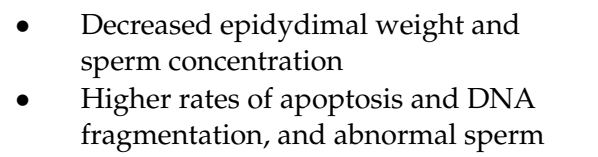 & $\begin{array}{l}\text { Imidacloprid has a negative } \\
\text { effect on the male rat } \\
\text { reproductive system. }\end{array}$ & [250] \\
\hline Imidacloprid & 90 days & $\begin{array}{l}5 \mathrm{mg} / \mathrm{kg} / \text { day } \\
10 \mathrm{mg} / \mathrm{kg} / \text { day } \\
20 \mathrm{mg} / \mathrm{kg} / \text { day }\end{array}$ & Female rats & $\begin{array}{l}\text { - Decreased ovarian weight, } \\
\text { pathomorphological changes in follicles } \\
\text { Alterations in levels of LH, FSH, } \\
\text { and progesterone }\end{array}$ & $\begin{array}{l}\text { Imidacloprid is toxic to the } \\
\text { ovary in female rats. }\end{array}$ & [251] \\
\hline Clothianidin & 90 days & $\begin{array}{l}2 \mathrm{mg} / \mathrm{kg} / \text { day } \\
8 \mathrm{mg} / \mathrm{kg} / \text { day } \\
24 \mathrm{mg} / \mathrm{kg} / \text { day }\end{array}$ & Male rats & $\begin{array}{l}\text { - Decreased epidydimal weight, and } \\
\text { weights of seminal vesicle, } \\
\text { Elevated palmitic, linoleic, and } \\
\text { arachidonic acids in testes }\end{array}$ & $\begin{array}{l}\text { Clothianidin has a negative } \\
\text { effect on the male rat } \\
\text { reproductive system. }\end{array}$ & [252] \\
\hline Atrazine and & Lifetime & $\begin{array}{l}\text { Missouri: } 0.17 \mathrm{mg} / 1 \\
\text { Minnesota: } 0.07 \mathrm{mg} / \mathrm{l}\end{array}$ & $\begin{array}{l}86 \text { men from } \\
\text { Missouri and } \\
\text { Minnesota, US }\end{array}$ & - $\quad$ Reduced sperm count & $\begin{array}{l}\text { Atrazine exposure in men } \\
\text { can reduce their sperm count. }\end{array}$ & [253] \\
\hline
\end{tabular}


Table 7. Cont.

\begin{tabular}{|c|c|c|c|c|c|c|}
\hline Chemical & $\begin{array}{l}\text { Exposure } \\
\text { Window }\end{array}$ & Dose & $\begin{array}{l}\text { Model/Study } \\
\text { Population }\end{array}$ & Effects & Conclusion & Reference \\
\hline $\begin{array}{l}\text { Atrazine and } \\
\text { Metolachlor }\end{array}$ & Intrauterine & $2.2 \mathrm{mg} / \mathrm{l}$ & $\begin{array}{l}\text { Women living in } \\
13 \text { communities } \\
\text { served by the } \\
\text { Rathbun water } \\
\text { system in Iowa, } \\
\text { US }\end{array}$ & - Intrauterine growth retardation & $\begin{array}{l}\text { Women with high atrazine } \\
\text { exposure are susceptible to } \\
\text { intrauterine growth } \\
\text { retardation. }\end{array}$ & [254] \\
\hline $\begin{array}{l}\text { Malathion and } \\
\text { diazinon }\end{array}$ & $\begin{array}{l}\text { Exposure during } \\
\text { first trimester of } \\
\text { pregnancy }\end{array}$ & & $\begin{array}{l}\text { Women at } \\
\text { approximately } 22 \\
\text { weeks of gestation } \\
\text { in Sicily, Italy }\end{array}$ & $\begin{array}{l}\text { - Higher incidence of } \\
\text { gestational hypertension }\end{array}$ & $\begin{array}{l}\text { Women with } \\
\text { organophosphorus pesticide } \\
\text { exposure in their first } \\
\text { trimester of pregnancy have } \\
\text { greater incidence of } \\
\text { gestational hypertension. }\end{array}$ & [18] \\
\hline
\end{tabular}




\subsubsection{Humans}

Several epidemiological studies have shown associations between atrazine exposure and adult reproductive outcomes in people. In a study of fertile men in agricultural Missouri in the US, men exposed to atrazine, alachlor, and diazinon had $40 \%$ lower sperm counts compared to men in US urban areas. After controlling for potential confounding factors, the highest correlation was found between reduced sperm count and high concentrations of atrazine in urine [253]. In a comparison of 13 communities receiving drinking water with elevated levels of atrazine to nearby communities receiving water from other sources, levels of atrazine, metolachlor, and cyanazine were each significant predictors of age-adjusted community rates of intrauterine growth retardation. This association was strongest for atrazine [254]. The mechanisms by which atrazine causes toxicity likely stem from it being an endocrine disrupting chemical that mediates reproductive abnormalities through targeting the HPG axis [255] (Table 7).

\subsection{Effects of Simazine on the Reproductive System}

Simazine is the second most commonly detected triazene herbicide in surface and groundwater and is commonly used in urban areas [241]. Simazine $(16 \mathrm{ng} / \mathrm{L})$ was detected in all surface and tap water tested in Northern Italy [237].

\section{Non-Human Animals}

Several studies indicate that simazine causes reproductive toxicity in animal models. Female offspring of mice exposed to environmentally relevant doses of simazine had shortened anogenital distance, decreased whole body, ovarian, and uterine weights, and increased apoptotic granulosa cells in the ovaries compared to control [241]. Female Wistar rats exposed to simazine for 21 days experienced delayed vaginal opening, decreased numbers of normal cycles, late onset of first estrus, and decreased prolactin compared to control [242]. Male offspring exposed to simazine in utero had decreased body, testicular, and epididymal weights, increased testicular apoptosis, and decreased sperm concentrations compared to control [243]. Leydig cells exposed to atrazine and simazine had dose-dependent increases in progesterone and testosterone compared to controls. These endpoints were mediated by the induction of Star, Hsd3b6, Hsd17b3, and the downregulation of Hsd3b1, Cyp17a1, and Srd5a1, which changed in a dose-dependent manner [256] (Table 7).

\subsection{Effects of Metolachlor on the Reproductive System}

Along with atrazine, metolachlor is one of the most consistently detected herbicides in the world. Environmental monitoring studies in the US have detected appreciable concentrations of metolachlor in drinking water sources in North Carolina (17-5866 ng/L), Georgia (0.09-10.5 $\mu \mathrm{g} / \mathrm{L})$, and 53\% of drinking water sources in California in the US [257-259]. Metolachlor has been detected in 54\% of the drinking water in Zegrab Croatia, more than 50\% of the water sources sampled in La Rioja Spain, and $31.4 \%$ of samples tested in the Guangxi province of China $[235,236,260]$.

\subsubsection{Non-Human Animals}

Prepubertal Wistar rats exposed to metolachlor had increased serum concentrations of testosterone, estradiol, and FSH, a reduction in dihydrotestosterone (DHT), and no change in LH compared to control. Metolachlor-treated male rats also had increased fluid in their seminal vesicles, early onset of puberty, and morphological abnormalities of seminiferous epithelium compared to control [244] (Table 7).

\subsubsection{Humans}

Metolachlor contamination in drinking water was found to be a significant predictor of intrauterine growth retardation in Iowa, US communities when compared to neighboring communities whose water was not contaminated with metolachlor [254] (Table 7). 


\subsection{Effects of Acetochlor on the Reproductive System}

Similar to the herbicides mentioned above, acetochlor has been identified as a leading water contaminant globally. This herbicide has been detected in $66.9 \%$ of the China's source and drinking water, with an average concentration of $33.9 \mathrm{ng} / \mathrm{L}$ [261]. More recently, $32 \%$ of drinking water in Croatia (107-117 ng/L) was found to be contaminated with acetochlor [235].

\section{Non-Human Animals}

Acetochlor has been recognized as an endocrine disrupting chemical by the USEPA and European Environmental Agency. Further, male mice exposed to acetochlor had significantly increased epididymal weight compared to control. Testicular tissues of exposed mice also had decreased superoxide dismutase and glutathione activity and increased malondialdehyde activity, which can collectively lead to increased ROS in the testis [245]. Neonatal exposure to acetochlor has been shown to alter pubertal development in female rats by accelerating vaginal opening and altering estrous cyclicity [246] (Table 7).

\subsection{Effects of Organophosphates on the Reproductive System}

\section{Non-Human Animals}

Several studies have shown that organophosphates are reproductive toxicants. Malathion was found to significantly lower sperm motility and quantity and to increase rates of sperm malformation in rats. Treatment with malathion also disrupted expression of apoptotic factors in the testes of rats by downregulating $\mathrm{Bcl}-2$, which is an anti-apoptotic factor, and upregulating $\mathrm{Bax}$, which is a pro-apoptotic factor [247]. Adult male rats exposed to chlorpyriphos were found to have decreased sperm count, sperm viability, and sperm motility as well as increased DNA damage in sperm cells. They also had arrested spermatogenesis, negative tubular differentiation and repopulation indexes, and decreased Leydig cell numbers compared to controls [248]. Another study found that male rats treated with chlorpyriphos exposure had significantly increased serum LH and decreased serum testosterone levels [249] (Table 7).

\subsection{Effects of Neocotinoides on the Reproductive System}

Neonicotinoids, a relatively new class of insecticides, pose a unique threat to drinking water supplies. Their unifying property as synthetic neonicotinoid derivatives makes them very small molecules that are water soluble, thus increasing the likelihood that they will leach out of soils and remain in drinking water sources for quite some time. Researchers in central China found neonicotinoids in all raw, finished, and tap water samples originating from the Han River and Yangtzee River in central China. The median sum concentration of all the neonicotinoids in these samples was $27.7 \mathrm{ng} / \mathrm{L}$, with a range of 13.4-186 ng/L [262]. Clothianidin, imidacloprid, and thiamethoxam have been detected in finished drinking water in the Midwest US, with concentrations ranging from $0.24 \mathrm{ng} / \mathrm{L}$ to $57.3 \mathrm{ng} / \mathrm{L}$ [263]. Their presence in finished drinking water globally exemplifies their persistence during conventional water treatment as well as the elevated risk of exposure to humans and non-human animals (Table 7).

\section{Non-Human Animals}

Despite being a new class of insecticides, evidence already exists that neonicotinoids are reproductive toxicants. In developing male rats, treatment with imidacloprid resulted in decreased sperm concentration, increased apoptosis and seminal DNA fragmentation, decreased serum testosterone, and decreased glutathione in the testis [250]. Adult females exposed to imidacloprid had decreased ovarian weight, increased FSH, and decreased LH and progesterone levels in serum, increased lactoperoxidase activity in the ovary, and decreased antioxidant capabilities in the ovary [251]. Adult 
male rats exposed to clothianidin had significantly decreased epididymal weights and elevated palmitic, linoleic, and arachidonic acids in their testes [252]. Male mice exposed to clothianidin experienced these same pathologies, and they also exhibited decreased glutathione peroxidase immunoreactivity. Despite their growing popularity and hydrophilic chemical composition, regulations are not in place for neonicotinoid contamination in drinking water (Table 7).

Since one of the sources of exposure to pesticides is ingestion of water and food, future studies should focus on the cumulative effects of different pesticides on the endocrine and reproductive systems. In addition, studies on the underlying mechanisms of toxicity of pesticides are crucial for understanding the toxic effects in non-human animals and humans and for developing appropriate strategies to reduce risk of pesticide toxicity.

\section{Estrogens}

Natural and synthetic estrogens are contaminants in the environment [264,265]. These compounds are endocrine disruptors that can alter gonadal steroid signaling by interacting with estrogen receptors [266]. The most prevalent estrogens found in the environment are estrone, $17 \beta$-estradiol, $17 \alpha$-estradiol, and estriol. These estrogens are naturally produced by humans and non-human animals [267]. Natural phytoestrogens from plants are also released in the environment [268]. Environmental contamination with estrogens has become a public health concern because of the ability of these compounds to disrupt the endocrine system, impair reproductive function, and trigger adverse health effects [269].

\subsection{Sources of Exposure to Estrogens}

The sources of estrogens in the environment can be diverse. The cattle industry is one major source of estrogens released into the environment, especially because the industry uses growth-regulating steroids to enhance cattle growth rates [265]. Further, estrogens have been detected in solid waste and effluents from livestock and agricultural areas [270]. Moreover, water has been polluted with estrogens released from sewage plants. The human source of estrogens is mainly through urine excretion. For example, pregnant women excrete between 260 and $790 \mu \mathrm{g} /$ day of estrone, 280 to $600 \mu \mathrm{g} / \mathrm{day}$ of $17 \beta$-estradiol, and 6000 and 10,000 $\mu \mathrm{g} /$ day of estriol [265]. Although ethinylestradiol from birth control pills is an additional endocrine disrupting chemical that contributes to the feminization of aquatic species, the contribution of this compound to drinking water estrogenicity has been shown to be less than that from other sources [271]. This could be because the only source of ethinylestradiol in drinking water is assumed to be therapeutic use and this compound transforms to estrone under all but nitrate-reducing conditions [272,273].

Estrogens are found in rivers, wastewater, and drinking water. For instance, estrone was the most commonly detected estrogen in water samples derived from streams associated with livestock operations in 12 states in the US [274]. Liu et al. estimated that the amount of estrogens from livestock $\left(56.8 \mathrm{~g} \cdot \mathrm{d}^{-1}\right)$ released into water environments was nearly two-fold higher than from humans (35.2 $\mathrm{g} \cdot \mathrm{d}^{-1}$ ) in Shangai [275]. Further, estriol was present in the highest average concentrations (summer: $3.6 \mathrm{ng} / \mathrm{L}$; winter: $2.7 \mathrm{ng} / \mathrm{L}$ ) followed by $17 \alpha$-estradiol in analyzed water samples from the Hanjiang River in China [276]. In addition, ethinylestradiol and estriol were the main estrogens responsible for the estrogenic potencies in samples of source and drinking water in eastern China. Moreover, a study revealed the existence of $17 \beta$-estradiol and ethinylestradiol in water samples collected from Meiliang Bay, China. Esteban et al. detected estriol 3-sulfate, estrone, and its metabolite at frequencies of $14 \%$ and $29 \%$ in analyzed samples of sewage treatment plants in the Madrid region [277]. 


\subsection{Effects of Environmental Estrogens on Reproduction}

\subsubsection{Non-Human Animals}

Exposure to estrogens present in the environment is known to impair development and reproductive function. For example, a study conducted in northwestern Ontario, Canada showed that chronic exposure to low levels of ethynylestradiol led to the feminization of male fishes through the production of vitellogenin mRNA and protein, impacts on gonadal development, and altered oogenesis in fish [278]. Further, exposure to estrogens present in effluents and in downstream waters caused feminized male fishes to have elevated concentrations of the egg yolk protein precursor (vitellogenin), decreased testes size, loss of secondary sex characteristics, and intersex [279-282]. In addition, Huang et al. observed strong estrogenic effects associated with the concentration of estrogens (estrone, 17 $\beta$-estradiol, and diethylstilbestrol) in mosquitofish in China [283]. Exposure to ethynylestradiol affected metamorphosis and altered sex ratios in frogs during vulnerable periods of development [284] (Table 8).

Mice and rats also have been shown to be sensitive to environmental estrogens. Specifically, Derouiche et al. showed that $17 \alpha$-ethinylestradiol-exposed mice males and their progeny expressed increased sexual behavior in a dose-dependent manner [23]. In a recent study, Meyer et al. demonstrated that prenatal exposure to low doses of $17 \alpha$-ethinylestradiol (environmentally relevant concentrations) impaired remodeling of the spiral arteries, increased the weight of the placenta, and increased the number of pups large for gestational age in mice [24]. In addition, prenatal exposure to $17 \alpha$-ethinylestradiol caused high abortion rates and modifications of maternal behavior in rats [25]. Prepubertal exposure to $17 \alpha$-ethinylestradiol advanced puberty, increased kisspeptin signaling to GnRH neurons, and increased Gnrh expression [285]. 
Table 8. Effects of Environmental Estrogens on the Reproductive System.

\begin{tabular}{|c|c|c|c|c|c|c|}
\hline Chemical & $\begin{array}{l}\text { Exposure } \\
\text { Window }\end{array}$ & Dose & $\begin{array}{l}\text { Model/Study } \\
\text { Population }\end{array}$ & Effects & Conclusion & Reference \\
\hline $\begin{array}{l}17 \alpha- \\
\text { ethynylestradiol }\end{array}$ & $\begin{array}{l}\text { Chronic } \\
\text { exposure }\end{array}$ & $5-6 \mathrm{ng} / \mathrm{L}$ & $\begin{array}{l}\text { Fish fathead minnow } \\
\text { (Pimephales promelas) } \\
\text { in northwestern } \\
\text { Ontario, Canada }\end{array}$ & $\begin{array}{l}\text { - Feminization of males through } \\
\text { the production of vitellogenin } \\
\text { mRNA and protein } \\
\text { Impacted gonadal development } \\
\text { as evidenced by intersex in males } \\
\text { and altered oogenesis in females } \\
\text { - A near extinction of this species } \\
\text { from the lake }\end{array}$ & $\begin{array}{l}\text { Concentrations of estrogens } \\
\text { and their mimics observed in } \\
\text { freshwaters can impact the } \\
\text { sustainability of wild fish } \\
\text { populations. }\end{array}$ & [278] \\
\hline N/A & $\begin{array}{l}\text { Chronic } \\
\text { exposure }\end{array}$ & N/A & $\begin{array}{l}\text { Fish (Greenside } \\
\text { Darters Etheostoma } \\
\text { blennioides and } \\
\text { Rainbow Darters E. } \\
\text { caeruleum) in } \\
\text { The Grand River } \\
\text { watershed in Ontario, } \\
\text { Canada }\end{array}$ & $\begin{array}{l}\text { Impaired capacity to produce } \\
\text { testosterone and } \\
\text { 11-ketotestosterone in vitro, and } \\
\text { in cellular development (GSI, } \\
\text { intersex) in male fish } \\
\text { - Rates of intersex were elevated }\end{array}$ & $\begin{array}{l}\text { Urban stretches of river are } \\
\text { exposed to estrogenic } \\
\text { compounds (man-made or } \\
\text { otherwise), causing adverse } \\
\text { biological effects (intersex in } \\
\text { males) that might impair } \\
\text { their ability to reproduce } \\
\text { normally. }\end{array}$ & [279] \\
\hline N/A & $\begin{array}{l}\text { Chronic } \\
\text { exposure }\end{array}$ & N/A & $\begin{array}{l}\text { Wild fish sampled } \\
\text { from rivers, lakes, or } \\
\text { canals in British Isles, } \\
\text { UK }\end{array}$ & $\begin{array}{l}\text { High incidence of intersexuality } \\
\text { in wild populations of riverine } \\
\text { fish (roach; Rutilus rutilus) }\end{array}$ & $\begin{array}{l}\text { Environmental estrogens my } \\
\text { cause widespread sexual } \\
\text { disruption in wild } \\
\text { populations. }\end{array}$ & [280] \\
\hline
\end{tabular}


Table 8. Cont.

\begin{tabular}{|c|c|c|c|c|c|c|}
\hline Chemical & $\begin{array}{l}\text { Exposure } \\
\text { Window }\end{array}$ & Dose & $\begin{array}{l}\text { Model/Study } \\
\text { Population }\end{array}$ & Effects & Conclusion & Reference \\
\hline $\begin{array}{l}17 \beta \text {-estradiol, } \\
\text { estrone, estriol, and } \\
17 \alpha \text {-ethynylestradiol, }\end{array}$ & $\begin{array}{l}\text { Adult } \\
\text { exposure }\end{array}$ & $\begin{array}{l}\text { Estrone and } \\
17 \beta \text {-estradiol } \\
\text { concentrations ranged } \\
\text { from }<2.0 \text { to }>75 \mathrm{ng} / \mathrm{L} \text {. } \\
\text { Estriol concentrations } \\
1.2 \pm 0.7 \mathrm{ng} / \mathrm{L} \text { and } \\
17 \alpha \text {-ethynylestradiol } \\
3.4 \pm 3.2 \mathrm{ng} / \mathrm{l} .\end{array}$ & $\begin{array}{l}\text { Adult male fathead } \\
\text { minnows (Pimephales } \\
\text { promelas). Study } \\
\text { conducted in } \\
\text { Colorado, US }\end{array}$ & $\begin{array}{l}\text { - Primary (sperm abundance) and } \\
\text { secondary (nuptial tubercles and } \\
\text { dorsal fat pads) sex } \\
\text { characteristics } \\
\text { were demasculinized } \\
\text { Vitellogenin was } \\
\text { maximally elevated }\end{array}$ & $\begin{array}{l}\text { The reproductive disruption } \\
\text { observed in this watershed is } \\
\text { due to endocrine-active } \\
\text { chemicals in the Colorado } \\
\text { wastewater treatment plant } \\
\text { effluent. }\end{array}$ & [281] \\
\hline $\begin{array}{l}\text { Estrone, } \\
17 \beta \text {-estradiol, and } \\
\text { diethylstilbestrol }\end{array}$ & $\begin{array}{l}\text { Adult } \\
\text { exposure }\end{array}$ & $\begin{array}{l}\text { Maximum } \\
\text { concentrations } \\
\text { detected for estrone, } \\
17 \beta \text {-estradiol, and } \\
\text { diethylstilbestrol in } \\
\text { surface waters were } \\
32.0 \mathrm{ng} / \mathrm{L}, 3.7 \mathrm{ng} / \mathrm{L} \text { and } \\
22.0 \mathrm{ng} / \mathrm{L}, \\
\text { respectively. }\end{array}$ & $\begin{array}{l}\text { Mosquitofish } \\
\text { (Gambusia affinis) in } \\
\text { rivers in South China }\end{array}$ & $\begin{array}{l}\text { - Induction of vitellogenin and } \\
\mathrm{ER} \alpha \text { mRNA in the livers of the } \\
\text { males and a gonopodium-like } \\
\text { anal fin in the females collected at } \\
\text { the majority of sites } \\
\text { Chemical concentrations } \\
\text { obtained by in vitro bioassays } \\
\text { and chemical analysis had } \\
\text { significant correlations with some } \\
\text { of the endpoints for the } \\
\text { estrogenic and/or androgenic } \\
\text { effects in mosquitofish }\end{array}$ & $\begin{array}{l}\text { Estrogens and androgens } \\
\text { present in rivers could cause } \\
\text { the observed estrogenic and } \\
\text { androgenic effects in } \\
\text { mosquitofish. }\end{array}$ & [283] \\
\hline $17 \alpha$-ethinylestradiol & $\begin{array}{l}\text { Developmental } \\
\text { exposure }\end{array}$ & $\begin{array}{l}5 \mathrm{nM} \text { of } \\
17 \alpha \text {-ethinylestradiol. }\end{array}$ & $\begin{array}{l}\text { Northern leopard frog } \\
\text { (Rana pipiens) }\end{array}$ & $\begin{array}{l}\text { - Delayed in development } \\
\text { immediately following exposure } \\
\text { Tadpoles exposed early in } \\
\text { development displayed a strong } \\
\text { female-biased sex ratio compared } \\
\text { to the controls. }\end{array}$ & $\begin{array}{l}\text { Estrogen exposure can lead } \\
\text { to significant delays in } \\
\text { metamorphic development } \\
\text { and result in feminized sex } \\
\text { ratios both immediately } \\
\text { following exposure and } \\
\text { persisting through to } \\
\text { metamorphic climax. }\end{array}$ & [284] \\
\hline
\end{tabular}


Table 8. Cont

\begin{tabular}{|c|c|c|c|c|c|c|}
\hline Chemical & $\begin{array}{l}\text { Exposure } \\
\text { Window }\end{array}$ & Dose & $\begin{array}{l}\text { Model/Study } \\
\text { Population }\end{array}$ & Effects & Conclusion & Reference \\
\hline $\begin{array}{l}\text { Ethinylestradiol } \\
\text { and zearalenone }\end{array}$ & $\begin{array}{l}\text { Adult } \\
\text { exposure }\end{array}$ & $\begin{array}{l}\text { Ethinylestradiol } \\
(10 \mu \mathrm{g} / \mathrm{kg}), \\
\text { zearalenone }(10 \\
\mathrm{mg} / \mathrm{kg}), \text { or vehicle for } \\
10 \text { days starting from } \\
\text { postnatal day } 18 .\end{array}$ & Wistar rats & $\begin{array}{l}\text { - Both zearalenone and } \\
\text { ethinylestradiol accelerated } \\
\text { vaginal opening, increased the } \\
\text { uterine weight and the number of } \\
\text { antral follicles in the ovary, and } \\
\text { resulted in increased central } \\
\text { expression of Gnrh } \\
\text { Increase of Kiss1 mRNA in the } \\
\text { anteroventral and rostral } \\
\text { periventricular hypothalamus } \\
\text { and an increased kisspeptin fiber } \\
\text { density and kisspeptin -GnRH } \\
\text { appositions in the preoptic area }\end{array}$ & $\begin{array}{l}\text { Exposure of peripubertal rats } \\
\text { to the structurally different } \\
\text { xenoestrogens ethinyl } \\
\text { estradiol and zearalenone } \\
\text { advances puberty onset, very } \\
\text { likely by } \\
\text { increasing/amplifying the } \\
\text { kisspeptinergic drive to } \\
\text { GnRH neurons. }\end{array}$ & [285] \\
\hline $\begin{array}{l}\text { Daidzein, equol, } \\
\text { genistein, } \\
\text { naringenin, } \\
\text { coumestrol, and } \\
\text { secoisolariciresinol }\end{array}$ & $\begin{array}{l}\text { Adult } \\
\text { exposure }\end{array}$ & $\begin{array}{l}\text { Phytoestrogens mean } \\
\text { levels in urine ranged } \\
\text { from } 0.34-64.16 \mu \mathrm{g} / \mathrm{g} \\
\text { of creatinine. }\end{array}$ & $\begin{array}{l}608 \text { idiopathic } \\
\text { infertile men and } 469 \\
\text { fertile controls in } \\
\text { China }\end{array}$ & $\begin{array}{l}\text { Exposures to daidzein, genistein } \\
\text { and secoisolariciresinol were } \\
\text { associated with idiopathic male } \\
\text { infertility with abnormal sperm } \\
\text { concentration, number per } \\
\text { ejaculum and motility }\end{array}$ & $\begin{array}{l}\text { Phytoestrogen exposures are } \\
\text { related to male reproductive } \\
\text { function and raise a public } \\
\text { health concern because } \\
\text { phytoestrogens exposure is } \\
\text { ubiquitous in China. }\end{array}$ & [286] \\
\hline
\end{tabular}




\subsubsection{Humans}

Exposure to exogenous estrogens has been associated with an increased risk of breast cancer in women in Spain [286]. Moreover, urinary phytoestrogens levels were associated with idiopathic infertility in men in China [287]. Together, these studies show that estrogens that contaminate surface waters worldwide can negatively influence the fertility and reproductive capacity of non-human animals and humans (Table 8).

Besides the information available about relationships between estrogens and adverse reproductive outcomes, data are limited on the levels and types of estrogens in the environment. In addition, the role of estrogen contamination in different ecosystems and populations is still not well understood. Future investigations should be conducted to fill these gaps in knowledge.

\section{Conclusions}

Growing evidence indicates that anthropogenic contaminants are present in water across the world and that they can impose negative health effects in non-human animals and humans. These environmental toxicants can act directly or indirectly on the reproductive system, impairing development and fertility. Considering that the routes of exposure to these chemicals are not restricted to the ingestion of water, the levels of exposure for some of these compounds can be much higher than those from water alone. Further studies in a wide variety of populations and species are required to explore the long-term consequences of exposure to contaminants present in water and their reproductive effects. Although the effects of chemicals among species may differ, non-human animal models serve as a basis for scientific experimentation as they provide mechanistic, effectiveness, and toxicological information about EDCs. Additionally, it is necessary to consider the effects of mixtures of contaminants from different categories to mimic the normal environmental exposure in domestic animals, wild life, and humans. More studies are needed in a variety of populations to determine if the impacts of environmental chemicals on reproduction differ by populations in different locations worldwide.

Author Contributions: A.G., V.E.M., and J.A.F. conceived the idea for this review. A.G. and V.E.M. wrote the initial drafts of the review and J.A.F. edited the drafts and obtained funding. All authors have read and agreed to the published version of the manuscript.

Funding: National Institute of Environmental Health, grant number R21 ES028963.

Conflicts of Interest: The authors declare no conflict of interest.

$\begin{array}{ll}\text { Abbreviations } \\ \text { EDCs } & \text { endocrine disruptor chemicals } \\ \text { USEPA } & \text { United States Environmental Protection Agency } \\ \text { BPA } & \text { bisphenol A } \\ \text { PFOA } & \text { perfluorooctanoic acid } \\ \text { PFOS } & \text { perfluorooctanesulfonic acid } \\ \text { DBPs } & \text { water disinfection byproducts } \\ \text { THMs } & \text { trihalomethanes } \\ \text { MCL } & \text { maximum contaminant level } \\ \text { HAAs } & \text { haloacetic acids } \\ \text { PFAS } & \text { perfluoroalkyl and polyfluoroalkyl substances } \\ \text { ROS } & \text { reactive oxygen species } \\ \text { USFDA } & \text { United States Food and Drug Administration } \\ \text { DEHP } & \text { di (2-ethylhexyl) phthalate } \\ \text { BBP } & \text { benzyl butyl phthalate } \\ \text { DiNP } & \text { di-isononyl phthalate } \\ \text { DnOP } & \text { di-n-octyl phthalate } \\ \text { DEP } & \text { diethyl phthalate }\end{array}$




$\begin{array}{ll}\text { DMP } & \text { dimethyl phthalate } \\ \text { DBP } & \text { dibutyl phthalate } \\ \text { DiBP } & \text { diisobutyl phthalate } \\ \text { MMP } & \text { monomethyl phthalate } \\ \text { MEP } & \text { monoethyl phthalate } \\ \text { MiBP } & \text { monoisobutyl phthalate } \\ \text { MnBP } & \text { mono-n-butyl phthalate } \\ \text { MEHP } & \text { mono-2-ethylhexyl phthalate } \\ \text { PET } & \text { polyethylene terephthalate } \\ \text { PND } & \text { postnatal day } \\ \text { USGS } & \text { United States Geological Survey } \\ \text { DDT } & \text { dichlorodiphenyltrichloroethane } \\ \text { FSH } & \text { follicle stimulating hormone } \\ \text { LH } & \text { luteinizing hormone }\end{array}$

\section{References}

1. Glassmeyer, S.T.; Furlong, E.T.; Kolpin, D.W.; Batt, A.L.; Benson, R.; Boone, J.S.; Conerly, O.; Donohue, M.J.; King, D.N.; Kostich, M.S.; et al. Nationwide reconnaissance of contaminants of emerging concern in source and treated drinking waters of the United States. Sci. Total. Environ. 2016, 581, 909-922. [CrossRef]

2. Richardson, S.D.; Ternes, T.A. Water Analysis: Emerging Contaminants and Current Issues. Anal. Chem. 2017, 90, 398-428. [CrossRef] [PubMed]

3. Environmental Protection Agency. Contaminant Candidate List (CCL) and Regulatory Determination. Available online: https://www.epa.gov/ccl/types-drinking-water-contaminants (accessed on 14 January 2020).

4. Smarr, M.; Kannan, K.; Louis, G.B. Endocrine disrupting chemicals and endometriosis. Fertil. Steril. 2016, 106, 959-966. [CrossRef] [PubMed]

5. Adoamnei, E.; Mendiola, J.; Vela-Soria, F.; Fernandez, M.F.; Olea, N.; Jørgensen, N.; Swan, S.; Torres-Cantero, A. Urinary bisphenol A concentrations are associated with reproductive parameters in young men. Environ. Res. 2018, 161, 122-128. [CrossRef]

6. Barakat, R.; Lin, P.-C.P.; Rattan, S.; Brehm, E.; Canisso, I.F.; Abosalum, M.E.; Flaws, J.A.; Hess, R.; Ko, C. Prenatal Exposure to DEHP Induces Premature Reproductive Senescence in Male Mice. Toxicol. Sci. 2017, 156, 96-108. [CrossRef] [PubMed]

7. Rattan, S.; Zhou, C.; Chiang, C.; Mahalingam, S.; Brehm, E.; Flaws, J.A. Exposure to endocrine disruptors during adulthood: Consequences for female fertility. J. Endocrinol. 2017, 233, R109-R129. [CrossRef] [PubMed]

8. Karwacka, A.; Zamkowska, D.; Radwan, M.; Jurewicz, J. Exposure to modern, widespread environmental endocrine disrupting chemicals and their effect on the reproductive potential of women: An overview of current epidemiological evidence. Hum. Fertil. 2017, 22, 2-25. [CrossRef]

9. Andrews, J.; Nichols, H.; Schmid, J.; Mole, L.; Hunter, E.; Klinefelter, G. Developmental toxicity of mixtures: The water disinfection by-products dichloro-, dibromo- and bromochloro acetic acid in rat embryo culture. Reprod. Toxicol. 2004, 19, 111-116. [CrossRef]

10. Pagé-Larivière, F.; Tremblay, A.; Campagna, C.; Rodriguez, M.J.; Sirard, M.-A. Low concentrations of bromodichloromethane induce a toxicogenomic response in porcine embryos in vitro. Reprod. Toxicol. 2016, 66, 44-55. [CrossRef]

11. Berger, A.; Ziv-Gal, A.; Cudiamat, J.; Wang, W.; Zhou, C.; Flaws, J.A. The effects of in utero bisphenol A exposure on the ovaries in multiple generations of mice. Reprod. Toxicol. 2015, 60, 39-52. [CrossRef]

12. Patel, S.; Brehm, E.; Gao, L.; Rattan, S.; Ziv-Gal, A.; Flaws, J.A. Bisphenol A Exposure, Ovarian Follicle Numbers, and Female Sex Steroid Hormone Levels: Results From a CLARITY-BPA Study. Endocrinologyy 2017, 158, 1727-1738. [CrossRef] [PubMed]

13. Li, Q.; Davila, J.; Kannan, A.; Flaws, J.A.; Bagchi, M.K.; Bagchi, I.C. Chronic Exposure to Bisphenol A Affects Uterine Function During Early Pregnancy in Mice. Endocrinology 2016, 157, 1764-1774. [CrossRef] [PubMed]

14. Patel, S.; Zhou, C.; Rattan, S.; Flaws, J.A. Effects of Endocrine-Disrupting Chemicals on the Ovary1. Boil. Reprod. 2015, 93, 20. [CrossRef] [PubMed] 
15. Hannon, P.R.; Flaws, J.A. The Effects of Phthalates on the Ovary. Front. Endocrinol. 2015, 6, 8. [CrossRef] [PubMed]

16. Cai, W.; Ji, Y.; Song, X.; Guo, H.; Han, L.; Zhang, F.; Liu, X.; Zhang, H.; Zhu, B.; Xu, M. Effects of glyphosate exposure on sperm concentration in rodents: A systematic review and meta-analysis. Environ. Toxicol. Pharmacol. 2017, 55, 148-155. [CrossRef]

17. Morris, A. Exposure to pesticide residues linked to adverse pregnancy outcomes. Nat. Rev. Endocrinol. 2017, 14, 4. [CrossRef]

18. Ledda, C.; Fiore, M.; Santarelli, L.; Bracci, M.; Mascali, G.; D’Agati, M.G.; Busà, A.; Ferrante, M.; Rapisarda, V. Gestational Hypertension and Organophosphorus Pesticide Exposure: A Cross-Sectional Study. BioMed Res. Int. 2015, 2015, 1-5. [CrossRef]

19. Zhang, H.; Lu, Y.; Luo, B.; Yan, S.; Guo, X.; Dai, J. Proteomic Analysis of Mouse Testis Reveals Perfluorooctanoic Acid-Induced Reproductive Dysfunction via Direct Disturbance of Testicular Steroidogenic Machinery. J. Proteome Res. 2014, 13, 3370-3385. [CrossRef]

20. Ma, Y.; Yang, C.-Z.; Liu, X.; Zhao, B.; Chu, Y.; Li, H.-Z. [Study of Pregnancy Exposure to PFOS on Reproductive Toxicities and Mechanism in Male Offspring Rats]. Sichuan da xue xue bao. Yi xue ban/J. Sichuan Univ. Med Sci. Ed. 2015, 46, 564-567.

21. Šabović, I.; Cosci, I.; De Toni, L.; Ferramosca, A.; Stornaiuolo, M.; Di Nisio, A.; Dall'Acqua, S.; Garolla, A.; Foresta, C. Perfluoro-octanoic acid impairs sperm motility through the alteration of plasma membrane. J. Endocrinol. Investig. 2019, 1-12. [CrossRef]

22. Fei, C.; McLaughlin, J.K.; Lipworth, L.; Olsen, J. Maternal levels of perfluorinated chemicals and subfecundity. Hum. Reprod. 2009, 24, 1200-1205. [CrossRef] [PubMed]

23. Derouiche, L.; Keller, M.; Duittoz, A.H.; Pillon, D. Developmental exposure to Ethinylestradiol affects transgenerationally sexual behavior and neuroendocrine networks in male mice. Sci. Rep. 2015, 5, 17457. [CrossRef] [PubMed]

24. Meyer, N.; Santamaria, C.G.; Müller, J.E.; Schumacher, A.; Rodriguez, H.A.; Zenclussen, A. Exposure to $17 \alpha$-ethinyl estradiol during early pregnancy affects fetal growth and survival in mice. Environ. Pollut. 2019, 251, 493-501. [CrossRef] [PubMed]

25. Arabo, A.; Lefebvre, M.; Fermanel, M.; Caston, J. Administration of $17 \alpha$-ethinylestradiol during pregnancy elicits modifications of maternal behavior and emotional alteration of the offspring in the rat. Dev. Brain Res. 2005, 156, 93-103. [CrossRef]

26. Gray, N.F. Pathogen Control in Drinking Water. In Microbiology of Waterborne Diseases; Academic Press: Cambridge, MA, USA, 2014; pp. 537-569.

27. Richardson, S.D.; Postigo, C. Drinking Water Disinfection By-products. The Handbook of Environmental Chemistry 2011, 20, 93-137.

28. Hwang, B.-F.; Jaakkola, M.S.; Guo, H.-R. Water disinfection by-products and the risk of specific birth defects: A population-based cross-sectional study in Taiwan. Environ. Heal. 2008, 7, 23. [CrossRef] [PubMed]

29. Righi, E.; Bechtold, P.; Tortorici, D.; Lauriola, P.; Calzolari, E.; Astolfi, G.; Nieuwenhuijsen, M.J.; Fantuzzi, G.; Aggazzotti, G. Trihalomethanes, chlorite, chlorate in drinking water and risk of congenital anomalies: A population-based case-control study in Northern Italy. Environ. Res. 2012, 116, 66-73. [CrossRef]

30. Villanueva, C.; Cantor, K.P.; Cordier, S.; Jaakkola, J.J.K.; King, W.D.; Lynch, C.F.; Porru, S.; Kogevinas, M. Disinfection byproducts and bladder cancer: A pooled analysis. Epidemiology 2004, 15, 357-367. [CrossRef]

31. E Bove, G.; Rogerson, P.A.; E Vena, J. Case control study of the geographic variability of exposure to disinfectant byproducts and risk for rectal cancer. Int. J. Heal. Geogr. 2007, 6, 18. [CrossRef]

32. Regli, S.; Chen, J.; Messner, M.; Elovitz, M.S.; Letkiewicz, F.J.; Pegram, R.A.; Pepping, T.; Richardson, S.D.; Wright, J.M. Estimating Potential Increased Bladder Cancer Risk Due to Increased Bromide Concentrations in Sources of Disinfected Drinking Waters. Environ. Sci. Technol. 2015, 49, 13094-13102. [CrossRef]

33. Zhai, H.; Zhang, X. Formation and Decomposition of New and Unknown Polar Brominated Disinfection Byproducts during Chlorination. Environ. Sci. Technol. 2011, 45, 2194-2201. [CrossRef] [PubMed]

34. Soyluoglu, M.; Ersan, M.S.; Ateia, M.; Karanfil, T. Removal of bromide from natural waters: Bromide-selective vs. conventional ion exchange resins. Chemosphere 2020, 238, 124583. [CrossRef] [PubMed]

35. Ersan, M.S.; Liu, C.; Amy, G.; Plewa, M.J.; Wagner, E.D.; Karanfil, T. Chloramination of iodide-containing waters: Formation of iodinated disinfection byproducts and toxicity correlation with total organic halides of treated waters. Sci. Total. Environ. 2019, 697, 134142. [CrossRef] [PubMed] 
36. Network Time Protocol. Revised Draft: Report on Carcinogens Monograph on Haloacetic Acids Found as Water Disinfection By-Products, U.S.D.o.H.a.H. Services, Editor. 2017, Office of the Report on Carcinogens, Division of the National Toxicology Program, National Institute of Environmental Health Sciences, U.S. Department of Health and Human Services USA. 2017. Available online: https://www.federalregister.gov/documents/2017/06/23/2017-13159/draft-reporton-carcinogens-monograph-on-haloacetic-acids-found-as-water-disinfection-by-products (accessed on 14 January 2020).

37. Richardson, S.D.; Plewa, M.J.; Wagner, E.D.; Schoeny, R.; DeMarini, D.M. Occurrence, genotoxicity, and carcinogenicity of regulated and emerging disinfection by-products in drinking water: A review and roadmap for research. Mutat. Res. Mutat. Res. 2007, 636, 178-242. [CrossRef] [PubMed]

38. U.S. Environmental Protection Agency. Comprehensive Disinfectants and Disinfection Byproducts Rules (Stage 1 and Stage 2): Quick Reference Guide; U.S. Environmental Protection Agency: Washington, DC, USA, 2010.

39. Cotruvo, J.; Amato, H. Trihalomethanes: Concentrations, Cancer Risks, and Regulations. J. Am. Water Work. Assoc. 2019, 111, 12-20. [CrossRef]

40. Seidel, C.J.; Samson, C.C.; Bartrand, T.; Ergul, A.; Summers, R.S.; Bartrand, T. Disinfection Byproduct Occurrence at Large Water Systems After Stage 2 DBPR. J. Am. Water Work. Assoc. 2017, 109, E287. [CrossRef]

41. Carter, R.; Joll, C.A. Occurrence and formation of disinfection by-products in the swimming pool environment: A critical review. J. Environ. Sci. 2017, 58, 19-50. [CrossRef]

42. Zwiener, C.; Richardson, S.D.; De Marini, D.M.; Grummt, T.; Glauner, T.; Frimmel, F.H. Drowning in Disinfection Byproducts? Assessing Swimming Pool Water. Environ. Sci. Technol. 2007, 41, 363-372. [CrossRef]

43. Daiber, E.J.; DeMarini, D.M.; Ravuri, S.A.; Liberatore, H.K.; Cuthbertson, A.A.; Thompson-Klemish, A.; Byer, J.D.; Schmid, J.E.; Afifi, M.Z.; Iii, E.R.B.; et al. Progressive Increase in Disinfection Byproducts and Mutagenicity from Source to Tap to Swimming Pool and Spa Water: Impact of Human Inputs. Environ. Sci. Technol. 2016, 50, 6652-6662. [CrossRef]

44. Teixido, E.; Pique, E.; Gonzalez-Linares, J.; Llobet, J.M.; Gómez-Catalán, J. Developmental effects and genotoxicity of 10 water disinfection by-products in zebrafish. J. Water Heal. 2015, 13, 54-66. [CrossRef]

45. Hanigan, D.; Truong, L.; Simonich, M.; Tanguay, R.; Westerhoff, P. Zebrafish embryo toxicity of 15 chlorinated, brominated, and iodinated disinfection by-products. J. Environ. Sci. 2017, 58, 302-310. [CrossRef] [PubMed]

46. Wang, C.; Yang, X.; Zheng, Q.; Moe, B.; Li, X.-F. Halobenzoquinone-Induced Developmental Toxicity, Oxidative Stress, and Apoptosis in Zebrafish Embryos. Environ. Sci. Technol. 2018, 52, 10590-10598. [CrossRef] [PubMed]

47. Hunter, E.S., 3rd; Rogers, E.H.; Schmid, J.E.; Richard, A. Comparative effects of haloacetic acids in whole embryo culture. Teratology 1996, 54, 5764. [CrossRef]

48. Bodensteiner, K.J.; Moeller, C.L.; Pau, K.-Y.F.; Klinefelter, G.R.; Veeramachaneni, D.N.R.; Sawyer, H.R.; Kane, C.M. Chronic Exposure to Dibromoacetic Acid, a Water Disinfection Byproduct, Diminishes Primordial Follicle Populations in the Rabbit. Toxicol. Sci. 2004, 80, 83-91. [CrossRef] [PubMed]

49. Jeong, C.H.; Gao, L.; Dettro, T.; Wagner, E.D.; Ricke, W.A.; Plewa, M.J.; Flaws, J.A. Monohaloacetic acid drinking water disinfection by-products inhibit follicle growth and steroidogenesis in mouse ovarian antral follicles in vitro. Reprod. Toxicol. 2016, 62,71-76. [CrossRef]

50. Gonsioroski, A.; Meling, D.D.; Gao, L.; Plewa, M.J.; Flaws, J.A. Iodoacetic acid inhibits follicle growth and alters expression of genes that regulate apoptosis, the cell cycle, estrogen receptors, and ovarian steroidogenesis in mouse ovarian follicles. Reprod. Toxicol. 2019, 91, 101-108. [CrossRef]

51. Narotsky, M.G.; Best, D.S.; McDonald, A.; Godin, E.A.; Hunter, E.S.; Simmons, J.E.; Iii, E.S.H. Pregnancy loss and eye malformations in offspring of F344 rats following gestational exposure to mixtures of regulated trihalomethanes and haloacetic acids. Reprod. Toxicol. 2011, 31, 59-65. [CrossRef]

52. Narotsky, M.G.; Klinefelter, G.R.; Goldman, J.M.; Best, D.S.; McDonald, A.; Strader, L.F.; Suárez, J.; Murr, A.S.; Thillainadarajah, I.; Hunter, E.S.; et al. Comprehensive Assessment of a Chlorinated Drinking Water Concentrate in a Rat Multigenerational Reproductive Toxicity Study. Environ. Sci. Technol. 2013, 47, 10653-10659. [CrossRef]

53. Melnick, R.; Nyska, A.; Foster, P.M.; Roycroft, J.H.; Kissling, G.E. Toxicity and carcinogenicity of the water disinfection byproduct, dibromoacetic acid, in rats and mice. Toxicology 2006, 230, 126-136. [CrossRef] 
54. Dodds, L.A.; King, W. Relation between trihalomethane compounds and birth defects. Occup. Environ. Med. 2001, 58, 443-446. [CrossRef]

55. Levallois, P.; Gingras, S.; Marcoux, S.; Legay, C.; Catto, C.; Rodriguez, M.; Tardif, R. Maternal Exposure to Drinking-water Chlorination By-products and Small-for-gestational-age Neonates. Epidemiology 2012, 23, 267-276. [CrossRef] [PubMed]

56. Smith, R.; Edwards, S.C.; Best, N.; Wright, J.; Nieuwenhuijsen, M.J.; Toledano, M.B. Birth Weight, Ethnicity, and Exposure to Trihalomethanes and Haloacetic Acids in Drinking Water during Pregnancy in the Born in Bradford Cohort. Environ. Heal. Perspect. 2015, 124, 681-689. [CrossRef] [PubMed]

57. Rivera-Núñez, Z.; Wright, J.M.; Meyer, A. Exposure to disinfectant by-products and the risk of stillbirth in Massachusetts. Occup. Environ. Med. 2018, 75, 742-751. [CrossRef] [PubMed]

58. Zeng, Q.; Li, M.; Xie, S.-H.; Gu, L.-J.; Yue, J.; Cao, W.-C.; Zheng, D.; Liu, A.-L.; Li, Y.-F.; Lu, W.-Q. Baseline blood trihalomethanes, semen parameters and serum total testosterone: A cross-sectional study in China. Environ. Int. 2013, 54, 134-140. [CrossRef]

59. Yang, P.; Zeng, Q.; Cao, W.-C.; Wang, Y.-X.; Huang, Z.; Li, J.; Liu, C.; Lu, W.-Q. Interactions between CYP2E1, GSTZ1 and GSTT1 polymorphisms and exposure to drinking water trihalomethanes and their association with semen quality. Environ. Res. 2016, 147, 445-452. [CrossRef]

60. Cummings, A.M.; Hedge, J.M. Dibromoacetic acid does not adversely affect early pregnancy in rats. Reprod. Toxicol. 1998, 12, 445-448. [CrossRef]

61. Weber, N.M.; Sawyer, H.R.; Legare, M.E.; Veeramachaneni, D.N.R. Sub-chronic Exposure to Dibromoacetic Acid, a Water Disinfection By-product, Does Not Affect Gametogenic Potential in Mice. Toxicol. Sci. 2005, 89, 325-330. [CrossRef]

62. Narotsky, M.G.; Klinefelter, G.R.; Goldman, J.M.; DeAngelo, A.B.; Best, D.S.; McDonald, A.; Strader, L.F.; Murr, A.S.; Suarez, J.D.; George, M.H.; et al. Reproductive Toxicity of a Mixture of Regulated Drinking-Water Disinfection By-Products in a Multigenerational Rat Bioassay. Environ. Heal. Perspect. 2015, 123, 564-570. [CrossRef]

63. MacLehose, R.F.; Savitz, D.A.; Herring, A.H.; Hartmann, K.E.; Singer, P.C.; Weinberg, H.S. Drinking Water Disinfection By-Products and Time to Pregnancy. Epidemiology 2008, 19, 451-458. [CrossRef]

64. Hoffman, C.S.; Mendola, P.; Savitz, D.A.; Herring, A.H.; Loomis, D.; Hartmann, K.E.; Singer, P.C.; Weinberg, H.S.; Olshan, A.F. Drinking Water Disinfection By-Product Exposure and Duration of Gestation. Epidemiology 2008, 19, 738-746. [CrossRef]

65. Ileka-Priouzeau, S.; Campagna, C.; Legay, C.; Deonandan, R.; Rodríguez, M.J.; Levallois, P. Women exposure during pregnancy to haloacetaldehydes and haloacetonitriles in drinking water and risk of small-for-gestational-age neonate. Environ. Res. 2015, 137, 338-348. [CrossRef] [PubMed]

66. King, W.; Dodds, L.; Allen, A.C.; Armson, B.; Fell, D.; Nimrod, C. Haloacetic acids in drinking water and risk for stillbirth. Occupational and Environmental Medicine 2005, 62, 124-127. [CrossRef] [PubMed]

67. Kogevinas, M.; Bustamante, M.; Gracia-Lavedán, E.; Ballester, F.; Cordier, S.; Costet, N.; Espinosa, A.; Grazuleviciene, R.; Danilevičiūtè, A.; Ibarluzea, J.; et al. Drinking Water Disinfection By-products, Genetic Polymorphisms, and Birth Outcomes in a European Mother-Child Cohort Study. Epidemiology 2016, 27, 903-911. [CrossRef]

68. Nieuwenhuijsen, M.J.; Northstone, K.; Golding, J. Swimming and Birth Weight. Epidemiology 2002, 13, 725-728. [CrossRef] [PubMed]

69. Luben, T.J.; Olshan, A.F.; Herring, A.H.; Jeffay, S.; Strader, L.; Buus, R.M.; Chan, R.L.; Savitz, D.A.; Singer, P.C.; Weinberg, H.S.; et al. The Healthy Men Study: An Evaluation of Exposure to Disinfection By-Products in Tap Water and Sperm Quality. Environ. Heal. Perspect. 2007, 115, 1169-1176. [CrossRef] [PubMed]

70. Iszatt, N.; Nieuwenhuijsen, M.; Bennett, J.E.; Best, N.G.; Povey, A.C.; Pacey, A.; Moore, H.; Cherry, N.M.; Toledano, M.B. Chlorination by-products in tap water and semen quality in England and Wales. Occup. Environ. Med. 2013, 70, 754-760. [CrossRef]

71. Zeng, Q.; Zhou, B.; He, D.-L.; Wang, Y.-X.; Wang, M.; Yang, P.; Huang, Z.; Li, J.; Lu, W.-Q. Joint effects of trihalomethanes and trichloroacetic acid on semen quality: A population-based cross-sectional study in China. Environ. Pollut. 2016, 212, 544-549. [CrossRef]

72. Buck, R.; Franklin, J.; Berger, U.; Conder, J.M.; Cousins, I.T.; De Voogt, P.; Jensen, A.A.; Kannan, K.; A Mabury, S.; Van Leeuwen, S.P. Perfluoroalkyl and polyfluoroalkyl substances in the environment: Terminology, classification, and origins. Integr. Environ. Assess. Manag. 2011, 7, 513-541. [CrossRef] 
73. Agency for Toxic Substances and Disease Registry. The family tree of per- and polyfluoroalkyl substances (PFAS) for environmental health professionals. Names and abbreviations. 2017. Available online: https: //www.atsdr.cdc.gov/pfas/docs/PFAS_FamilyTree_EnvHealthPro-508.pdf (accessed on 10 January 2020).

74. Ng, A.; Weerakoon, D.; Lim, E.; Padhye, L.P. Fate of environmental pollutants. Water Environ. Res. 2019, 91, 1294-1325. [CrossRef]

75. Blake, B.E.; Pinney, S.M.; Hines, E.P.; Fenton, S.E.; Ferguson, K.K. Associations between longitudinal serum perfluoroalkyl substance (PFAS) levels and measures of thyroid hormone, kidney function, and body mass index in the Fernald Community Cohort. Environ. Pollut. 2018, 242, 894-904. [CrossRef]

76. Coperchini, F.; Awwad, O.; Rotondi, M.; Santini, F.; Imbriani, M.; Chiovato, L. Thyroid disruption by perfluorooctane sulfonate (PFOS) and perfluorooctanoate (PFOA). J. Endocrinol. Investig. 2016, 40, 105-121. [CrossRef] [PubMed]

77. Pierozan, P.; Jernerén, F.; Karlsson, O. Perfluorooctanoic acid (PFOA) exposure promotes proliferation, migration and invasion potential in human breast epithelial cells. Arch. Toxicol. 2018, 92, 1729-1739. [CrossRef] [PubMed]

78. Barry, V.; Winquist, A.; Steenland, K. Perfluorooctanoic Acid (PFOA) Exposures and Incident Cancers among Adults Living Near a Chemical Plant. Environ. Heal. Perspect. 2013, 121, 1313-1318. [CrossRef] [PubMed]

79. Jacquet, N.; Maire, M.A.; Rast, C.; Bonnard, M.; Vasseur, P. Perfluorooctanoic acid (PFOA) acts as a tumor promoter on Syrian hamster embryo (SHE) cells. Environ. Sci. Pollut. Res. 2012, 19, 2537-2549. [CrossRef]

80. Liang, X.; Xie, G.; Wu, X.; Su, M.; Yang, B. Effect of prenatal PFOS exposure on liver cell function in neonatal mice. Environ. Sci. Pollut. Res. 2019, 26, 18240-18246. [CrossRef]

81. Du, G.; Hu, J.; Huang, Z.; Yu, M.; Lu, C.; Wang, X.; Wu, D. Neonatal and juvenile exposure to perfluorooctanoate (PFOA) and perfluorooctane sulfonate (PFOS): Advance puberty onset and kisspeptin system disturbance in female rats. Ecotoxicol. Environ. Saf. 2019, 167, 412-421. [CrossRef]

82. Lai, K.P.; Lee, J.C.-Y.; Wan, H.T.; Li, J.W.; Wong, A.Y.-M.; Chan, T.-F.; Camille, O.; Galano, J.-M.; Durand, T.; Leung, K.S.; et al. Effects of in Utero PFOS Exposure on Transcriptome, Lipidome, and Function of Mouse Testis. Environ. Sci. Technol. 2017, 51, 8782-8794. [CrossRef]

83. Johansson, N.; Eriksson, P.; Viberg, H. Neonatal Exposure to PFOS and PFOA in Mice Results in Changes in Proteins which are Important for Neuronal Growth and Synaptogenesis in the Developing Brain. Toxicol. Sci. 2009, 108, 412-418. [CrossRef]

84. Oulhote, Y.; Steuerwald, U.; Debes, F.; Weihe, P.; Grandjean, P. Behavioral difficulties in 7-year old children in relation to developmental exposure to perfluorinated alkyl substances. Environ. Int. 2016, 97, 237-245. [CrossRef]

85. Agency for Toxic Substances and Disease Registry. Basic Information on PFAS. Available online: https: //www.epa.gov/pfas/basic-information-pfas\#tab-1 (accessed on 14 January 2020).

86. Kabore, H.A.; Duy, S.V.; Munoz, G.; Meite, L.; Desrosiers, M.; Liu, J.; Sory, T.K.; Sauvé, S. Worldwide drinking water occurrence and levels of newly-identified perfluoroalkyl and polyfluoroalkyl substances. Sci. Total. Environ. 2018, 616, 1089-1100. [CrossRef]

87. Zareitalabad, P.; Siemens, J.; Hamer, M.; Amelung, W. Perfluorooctanoic acid (PFOA) and perfluorooctanesulfonic acid (PFOS) in surface waters, sediments, soils and wastewater-A review on concentrations and distribution coefficients. Chemosphere 2013, 91, 725-732. [CrossRef] [PubMed]

88. Schwanz, T.G.; Llorca, M.; Farré, M.; Barceló, J. Perfluoroalkyl substances assessment in drinking waters from Brazil, France and Spain. Sci. Total. Environ. 2016, 539, 143-152. [CrossRef] [PubMed]

89. Mak, Y.L.; Taniyasu, S.; Yeung, L.W.; Lu, G.; Jin, L.; Yang, Y.; Lam, P.K.S.; Kannan, K.; Yamashita, N.; Lam, K.S.P. Perfluorinated Compounds in Tap Water from China and Several Other Countries. Environ. Sci. Technol. 2009, 43, 4824-4829. [CrossRef] [PubMed]

90. Chang, S.-C.; Das, K.; Ehresman, D.J.; E Ellefson, M.; Gorman, G.S.; Hart, J.A.; Noker, P.E.; Tan, Y.-M.; Lieder, P.H.; Lau, C.; et al. Comparative pharmacokinetics of perfluorobutyrate in rats, mice, monkeys, and humans and relevance to human exposure via drinking water. Toxicol. Sci. 2008, 104, 40-53. [CrossRef] [PubMed]

91. Lau, C.; Anitole, K.; Hodes, C.; Lai, D.; Pfahles-Hutchens, A.; Seed, J. Perfluoroalkyl Acids: A Review of Monitoring and Toxicological Findings. Toxicol. Sci. 2007, 99, 366-394. [CrossRef] [PubMed] 
92. Li, Y.; Fletcher, T.; Mucs, D.; Scott, K.; Lindh, C.H.; Tallving, P.; Jakobsson, K. Half-lives of PFOS, PFHxS and PFOA after end of exposure to contaminated drinking water. Occup. Environ. Med. 2017, 75, 46-51. [CrossRef]

93. USEPA. Historic EPA Summit Provides Active Engagement and Actions to Address PFAS. 2018. Available online: https://www.epa.gov/newsreleases/historic-epa-summit-provides-active-engagement-and-actionsaddress-pfas (accessed on 14 January 2020).

94. Lu, Y.; Luo, B.; Li, J.; Dai, J. Perfluorooctanoic acid disrupts the blood-testis barrier and activates the $\mathrm{TNF} \alpha / \mathrm{p} 38$ MAPK signaling pathway in vivo and in vitro. Arch. Toxicol. 2015, 90, 971-983. [CrossRef]

95. Song, P.; Li, D.; Wang, X.; Zhong, X. Effects of perfluorooctanoic acid exposure during pregnancy on the reproduction and development of male offspring mice. Andrologia 2018, 50, e13059. [CrossRef]

96. Li, L.; Li, X.; Chen, X.; Chen, Y.; Liu, J.; Chen, F.; Ge, F.; Ye, L.; Lian, Q.; Ge, R.-S. Perfluorooctane sulfonate impairs rat Leydig cell development during puberty. Chemosphere 2018, 190, 43-53. [CrossRef]

97. Zhao, Y.; Tan, Y.S.; Strynar, M.; Pérez, G.; Haslam, S.Z.; Yang, C. Perfluorooctanoic acid effects on ovaries mediate its inhibition of peripubertal mammary gland development in Balb/c and C57Bl/6 mice. Reprod. Toxicol. 2012, 33, 563-576. [CrossRef]

98. Chen, Y.; Zhou, L.; Xu, J.; Zhang, L.; Li, M.; Xie, X.; Xie, Y.; Luo, D.; Zhang, D.; Yu, X.; et al. Maternal exposure to perfluorooctanoic acid inhibits luteal function via oxidative stress and apoptosis in pregnant mice. Reprod. Toxicol. 2017, 69, 159-166. [CrossRef] [PubMed]

99. López-Arellano, P.; López-Arellano, K.; Luna, J.; Flores, D.; Jiménez-Salazar, J.; Gavia, G.; Teteltitla, M.; Rodríguez, J.J.; Domínguez, A.; Casas, E.; et al. Perfluorooctanoic acid disrupts gap junction intercellular communication and induces reactive oxygen species formation and apoptosis in mouse ovaries. Environ. Toxicol. 2018, 34, 92-98. [CrossRef] [PubMed]

100. Joensen, U.N.; Bossi, R.; Leffers, H.; Jensen, A.A.; Skakkebæk, N.E.; Jørgensen, N. Do Perfluoroalkyl Compounds Impair Human Semen Quality? Environ. Heal. Perspect. 2009, 117, 923-927. [CrossRef] [PubMed]

101. Vested, A.; Ramlau-Hansen, C.H.; Olsen, S.; Bonde, J.P.; Kristensen, S.L.; Halldorsson, T.I.; Becher, G.; Haug, L.S.; Ernst, E.H.; Toft, G. Associations of in Utero Exposure to Perfluorinated Alkyl Acids with Human Semen Quality and Reproductive Hormones in Adult Men. Environ. Heal. Perspect. 2013, 121, 453-458. [CrossRef] [PubMed]

102. Yuan, Y.; Ding, X.; Cheng, Y.; Kang, H.; Luo, T.; Zhang, X.; Kuang, H.; Chen, Y.; Zeng, X.; Zhang, D. PFOA evokes extracellular Ca2+ influx and compromises progesterone-induced response in human sperm. Chemosphere 2019, 241, 125074. [CrossRef] [PubMed]

103. Louis, G.B.; Peterson, C.M.; Chen, Z.; Hediger, M.L.; Croughan, M.S.; Sundaram, R.; Stanford, J.B.; Fujimoto, V.Y.; Varner, M.; Giudice, L.C.; et al. Perfluorochemicals and endometriosis: The ENDO study. Epidemiology 2012, 23, 799-805. [CrossRef] [PubMed]

104. Campbell, S.; Raza, M.; Pollack, A. Perfluoroalkyl substances and endometriosis in US women in NHANES 2003-2006. Reprod. Toxicol. 2016, 65, 230-235. [CrossRef]

105. Wang, B.; Zhang, R.; Jin, F.; Lou, H.; Mao, Y.; Zhu, W.; Zhou, W.; Zhang, P.; Zhang, J. Perfluoroalkyl substances and endometriosis-related infertility in Chinese women. Environ. Int. 2017, 102, 207-212. [CrossRef]

106. Barrett, E.S.; Chen, C.; Thurston, S.W.; Haug, L.S.; Sabaredzovic, A.; Fjeldheim, F.N.; Frydenberg, H.; Lipson, S.F.; Ellison, P.; Thune, I. Perfluoroalkyl substances and ovarian hormone concentrations in naturally cycling women. Fertil. Steril. 2015, 103, 1261-1270. [CrossRef]

107. Tsai, M.-S.; Lin, C.-Y.; Lin, C.-C.; Chen, M.-H.; Hsu, S.H.; Chien, K.-L.; Sung, F.-C.; Chen, P.-C.; Su, T.-C. Association between perfluoroalkyl substances and reproductive hormones in adolescents and young adults. Int. J. Hyg. Environ. Heal. 2015, 218, 437-443. [CrossRef]

108. Fei, C.; McLaughlin, J.K.; Tarone, R.E.; Olsen, J. Perfluorinated Chemicals and Fetal Growth: A Study within the Danish National Birth Cohort. Environ. Heal. Perspect. 2007, 115, 1677-1682. [CrossRef] [PubMed]

109. Velez, M.P.; Arbuckle, T.E.; Fraser, W.D. Maternal exposure to perfluorinated chemicals and reduced fecundity: The MIREC study. Hum. Reprod. 2015, 30, 701-709. [CrossRef] [PubMed]

110. Tian, Y.; Liang, H.; Miao, M.; Yang, F.; Ji, H.; Cao, W.; Liu, X.; Zhang, X.; Chen, A.; Xiao, H.; et al. Maternal plasma concentrations of perfluoroalkyl and polyfluoroalkyl substances during pregnancy and anogenital distance in male infants. Hum. Reprod. 2019, 34, 1356-1368. [CrossRef] [PubMed] 
111. Di Nisio, A.; Rocca, M.; Sabovic, I.; Ponce, M.D.R.; Corsini, C.; Guidolin, D.; Zanon, C.; Acquasaliente, L.; Carosso, A.; De Toni, L.; et al. Perfluorooctanoic acid alters progesterone activity in human endometrial cells and induces reproductive alterations in young women. Chemosphere 2020, 242, 125208. [CrossRef] [PubMed]

112. Di Nisio, A.; Sabovic, I.; Valente, U.; Tescari, S.; Rocca, M.S.; Guidolin, D.; Zengin, G.; Acquasaliente, L.; Pozzi, N.; Plebani, M.; et al. Endocrine Disruption of Androgenic Activity by Perfluoroalkyl Substances: Clinical and Experimental Evidence. J. Clin. Endocrinol. Metab. 2018, 104, 1259-1271. [CrossRef]

113. Lauritzen, H.B.; LaRose, T.L.; Øien, T.; Sandanger, T.M.; Odland, J.; Van De Bor, M.; Jacobsen, G.W. Maternal serum levels of perfluoroalkyl substances and organochlorines and indices of fetal growth: A Scandinavian case-cohort study. Pediatr. Res. 2016, 81, 33-42. [CrossRef]

114. Gomis, M.I.; Vestergren, R.; Borg, D.; Cousins, I.T. Comparing the toxic potency in vivo of long-chain perfluoroalkyl acids and fluorinated alternatives. Environ. Int. 2018, 113, 1-9. [CrossRef]

115. Fiege, H.; Voges, H.-W.; Hamamoto, T.; Umemura, S.; Iwata, T.; Miki, H.; Fujita, Y.; Buysch, H.-J.; Garbe, D.; Paulus, W. Phenol Derivatives. Ullmann's Encycl. Ind. Chem. 2000. [CrossRef]

116. U.S. Environmental Protection Agency. Risk Management for Bisphenol A (BPA). 2017. Available online: https: //www.epa.gov/assessing-and-managing-chemicals-under-tsca/risk-management-bisphenol-bpa (accessed on 14 January 2020).

117. NIEHS. Bisphenol A (BPA). 2019. Available online: https://www.niehs.nih.gov/health/topics/agents/sya-bpa/ index.cfm (accessed on 14 January 2020).

118. Diamanti-Kandarakis, E.; Bourguignon, J.-P.; Giudice, L.C.; Hauser, R.; Prins, G.S.; Soto, A.M.; Zoeller, R.T.; Gore, A.C. Endocrine-disrupting chemicals: An Endocrine Society scientific statement. Endocr. Rev. 2009, 30, 293-342. [CrossRef]

119. Konieczna, A.; Rutkowska, A.; Rachoń, D. Health risk of exposure to Bisphenol A (BPA). Roczniki Państwowego Zakładu Higieny 2015, 66, 5-11.

120. Prins, G.; Ye, S.-H.; Birch, L.; Zhang, X.; Cheong, A.; Lin, H.; Calderon-Gierszal, E.; Groen, J.; Hu, W.-Y.; Ho, S.-M.; et al. Prostate Cancer Risk and DNA Methylation Signatures in Aging Rats following Developmental BPA Exposure: A Dose-Response Analysis. Environ. Heal. Perspect. 2017, 125, 077007. [CrossRef] [PubMed]

121. Paulose, T.; Speroni, L.; Sonnenschein, C.; Soto, A. Estrogens in the wrong place at the wrong time: Fetal BPA exposure and mammary cancer. Reprod. Toxicol. 2014, 54, 58-65. [CrossRef] [PubMed]

122. Murata, M.; Kang, J.-H. Bisphenol A (BPA) and cell signaling pathways. Biotechnol. Adv. 2018, 36, 311-327. [CrossRef] [PubMed]

123. Go Canada. Canada Consumer Product Safety Act. 2010. Available online: https://laws-lois.justice.gc.ca/eng/ acts/c-1.68/CanadaConsumerProductSafetyActhttps://laws-lois.justice.gc.ca (accessed on 10 January 2020).

124. Willhite, C.C.; Daston, G.P. Bisphenol exposure, hazard and regulation. Toxicology 2019, 425, 152243. [CrossRef] [PubMed]

125. Function as a Service. LOI n ${ }^{\circ} 2010-729$ du 30 juin 2010 tendant à suspendre la commercialisation de tout conditionnement comportant du bisphénol A et destiné à recevoir des produits alimentaires. 2010. Available online: https://www.legifrance.gouv.fr/affichTexte.do?cidTexte=JORFTEXT000022414734 (accessed on 14 January 2020).

126. USFDA. Bisphenol A (BPA): Use in Food Contact Application. 2018. Available online: https://www.fda.gov/ food/food-additives-petitions/bisphenol-bpa-use-food-contact-application (accessed on 14 January 2020).

127. Vandenberg, L.N.; Colborn, T.; Hayes, T.B.; Heindel, J.J.; Jacobs, D.R.; Lee, D.-H.; Shioda, T.; Soto, A.M.; Saal, F.S.V.; Welshons, W.V.; et al. Hormones and endocrine-disrupting chemicals: Low-dose effects and nonmonotonic dose responses. Endocr. Rev. 2012, 33, 378-455. [CrossRef]

128. Vandenberg, L.N. Low-Dose Effects of Hormones and Endocrine Disruptors. Vitamins and Hormones 2014, 94, 129-165.

129. Santhi, V.; Sakai, N.; Ahmad, E.; Mustafa, A. Occurrence of bisphenol A in surface water, drinking water and plasma from Malaysia with exposure assessment from consumption of drinking water. Sci. Total. Environ. 2012, 427, 332-338. [CrossRef]

130. Wu, M.; Wang, L.; Xu, G.; Liu, N.; Tang, L.; Zheng, J.; Bu, T.; Lei, B. Seasonal and spatial distribution of 4-tert-octylphenol, 4-nonylphenol and bisphenol A in the Huangpu River and its tributaries, Shanghai, China. Environ. Monit. Assess. 2012, 185, 3149-3161. [CrossRef] 
131. Cheng, Y.-C.; Chen, H.-W.; Chen, W.-L.; Chen, C.-Y.; Wang, G.-S. Occurrence of nonylphenol and bisphenol A in household water pipes made of different materials. Environ. Monit. Assess. 2016, 188, 562. [CrossRef]

132. Wanda, E.; Nyoni, H.; Mamba, B.B.; Msagati, T.A.M. Occurrence of Emerging Micropollutants in Water Systems in Gauteng, Mpumalanga, and North West Provinces, South Africa. Int. J. Environ. Res. Public Heal. 2017, 14, 79. [CrossRef]

133. Colin, A.; Bach, C.; Rosin, C.; Munoz, J.-F.; Dauchy, X. Is Drinking Water a Major Route of Human Exposure to Alkylphenol and Bisphenol Contaminants in France? Arch. Environ. Contam. Toxicol. 2013, 66, 86-99. [CrossRef]

134. Karthikraj, R.; Kannan, K.; Karthikraj, R. Mass loading and removal of benzotriazoles, benzothiazoles, benzophenones, and bisphenols in Indian sewage treatment plants. Chemosphere 2017, 181, $216-223$. [CrossRef] [PubMed]

135. Sun, Q.; Wang, Y.; Li, Y.; Ashfaq, M.; Dai, L.; Xie, X.; Yu, C.-P. Fate and mass balance of bisphenol analogues in wastewater treatment plants in Xiamen City, China. Environ. Pollut. 2017, 225, 542-549. [CrossRef] [PubMed]

136. Sun, X.; Peng, J.; Wang, M.; Wang, J.; Tang, C.; Yang, L.; Lei, H.; Li, F.; Wang, X.; Chen, J. Determination of nine bisphenols in sewage and sludge using dummy molecularly imprinted solid-phase extraction coupled with liquid chromatography tandem mass spectrometry. J. Chromatogr. A 2018, 1552, 10-16. [CrossRef] [PubMed]

137. U.S. Environmental Protection Agency. Bisphenol A Action Plan; U.S. Environmental Protection Agency: Washington, DC, USA, 2010.

138. Wagner, M.; Oehlmann, J. Endocrine disruptors in bottled mineral water: Total estrogenic burden and migration from plastic bottles. Environ. Sci. Pollut. Res. 2009, 16, 278-286. [CrossRef] [PubMed]

139. Wang, X.; Chang, F.; Bai, Y.; Chen, F.; Zhang, J.; Chen, L. Bisphenol A enhances kisspeptin neurons in anteroventral periventricular nucleus of female mice. J. Endocrinol. 2014, 221, 201-213. [CrossRef]

140. Xu, G.; Han, A.; Xu, N.; Su, P. Effects of maternal exposure to bisphenol A during pregnancy on puberty in advance and hypothalamo-pituitary gonadal axis hormones level in female offspring. Wei sheng yan jiu/J. Hyg. Res. 2018, 47, 425-431.

141. Ramos, J.G.; Varayoud, J.; Kass, L.; Rodríguez, H.; Costabel, L.; Muñoz-De-Toro, M.; Luque, E.H. Bisphenol a induces both transient and permanent histofunctional alterations of the hypothalamic-pituitary-gonadal axis in prenatally exposed male rats. Endocrinology 2003, 144, 3206-3215. [CrossRef]

142. Xi, W.; Lee, C.K.F.; Yeung, W.S.; Giesy, J.P.; Wong, M.; Zhang, X.; Hecker, M.; Wong, C.K.C. Effect of perinatal and postnatal bisphenol A exposure to the regulatory circuits at the hypothalamus-pituitary-gonadal axis of CD-1 mice. Reprod. Toxicol. 2011, 31, 409-417. [CrossRef]

143. Wisniewski, P.; Romano, R.M.; Kizys, M.M.; Oliveira, K.C.; Kasamatsu, T.; Giannocco, G.; Chiamolera, M.I.; Da Silva, M.R.D.; Romano, M.A. Adult exposure to bisphenol A (BPA) in Wistar rats reduces sperm quality with disruption of the hypothalamic-pituitary-testicular axis. Toxicology 2015, 329, 1-9. [CrossRef]

144. Molina, A.; Abril, N.; Morales-Prieto, N.; Monterde, J.; Ayala, N.; Lora, A.; Moyano, R. Hypothalamic-pituitary-ovarian axis perturbation in the basis of bisphenol A (BPA) reproductive toxicity in female zebrafish (Danio rerio). Ecotoxicol. Environ. Saf. 2018, 156, 116-124. [CrossRef] [PubMed]

145. Aikawa, H.; Koyama, S.; Matsuda, M.; Nakahashi, K.; Akazome, Y.; Mori, T. Relief effect of vitamin A on the decreased motility of sperm and the increased incidence of malformed sperm in mice exposed neonatally to bisphenol A. Cell Tissue Res. 2004, 315, 119-124. [CrossRef] [PubMed]

146. Dobrzyńska, M.M.; Jankowska-Steifer, E.A.; Tyrkiel, E.J.; Gajowik, A.; Radzikowska, J.; Pachocki, K.A. Comparison of the effects of bisphenol A alone and in a combination with X-irradiation on sperm count and quality in male adult and pubescent mice. Environ. Toxicol. 2013, 29, 1301-1313. [CrossRef] [PubMed]

147. Vilela, J.M.V.; Hartmann, A.; Silva, E.F.; Cardoso, T.F.; Corcini, C.D.; Varela-Jr, A.S.; Martínez, P.; Colares, E.P. Sperm impairments in adult vesper mice (Calomys laucha) caused byin uteroexposure to bisphenol A. Andrologia 2013, 46, 971-978. [CrossRef]

148. Wang, H.-F.; Liu, M.; Li, N.; Luo, T.; Zheng, L.-P.; Zeng, X.-H. Bisphenol A impairs Mature Sperm Functions by a CatSper-Relevant Mechanism. Toxicol. Sci. 2016, 152, 145-154. [CrossRef]

149. Wu, B.; Pan, D.; Zheng, X.; Ding, H.; Ma, Z.; Xie, M.; Ge, S. Long-term effects of neonatal exposure to bisphenol A on testes structure and the expression of Boule in testes of male mice. Wei sheng yan jiu= J. Hyg. Res. 2017, 46, 975-980. 
150. Hindman, A.R.; Mo, X.M.; Helber, H.L.; Kovalchin, C.E.; Ravichandran, N.; Murphy, A.R.; Fagan, A.M.; John, P.M.S.; Burd, C. Varying Susceptibility of the Female Mammary Gland to In Utero Windows of BPA Exposure. Endocrinology 2017, 158, 3435-3447. [CrossRef]

151. Ibrahim, M.A.A.; Elbakry, R.H.; Bayomy, N. Effect of bisphenol A on morphology, apoptosis and proliferation in the resting mammary gland of the adult albino rat. Int. J. Exp. Pathol. 2016, 97, 27-36. [CrossRef]

152. Hu, Y.; Yuan, D.-Z.; Wu, Y.; Yu, L.-L.; Xu, L.; Yue, L.-M.; Liu, L.; Xu, W.-M.; Qiao, X.-Y.; Zeng, R.-J.; et al. Bisphenol A Initiates Excessive Premature Activation of Primordial Follicles in Mouse Ovaries via the PTEN Signaling Pathway. Reprod. Sci. 2017, 25, 609-620. [CrossRef]

153. Martínez-Peña, A.A.; Rivera-Baños, J.; Méndez-Carrillo, L.L.; Ramírez-Solano, M.I.; Galindo-Bustamante, A.; Páez-Franco, J.C.; Morimoto, S.; Gonzalez-Mariscal, L.; Cruz, M.E.; Mendoza-Rodríguez, C.A.; et al. Perinatal administration of bisphenol A alters the expression of tight junction proteins in the uterus and reduces the implantation rate. Reprod. Toxicol. 2017, 69, 106-120. [CrossRef]

154. Neff, A.M.; Blanco, S.C.; A Flaws, J.; Bagchi, I.C.; Bagchi, M.K. Chronic Exposure of Mice to Bisphenol-A Alters Uterine Fibroblast Growth Factor Signaling and Leads to Aberrant Epithelial Proliferation. Endocrinology 2019, 160, 1234-1246. [CrossRef] [PubMed]

155. Rytel, L. The Influence of Bisphenol A (BPA) on Neuregulin 1-Like Immunoreactive Nerve Fibers in the Wall of Porcine Uterus. Int. J. Mol. Sci. 2018, 19, 2962. [CrossRef] [PubMed]

156. Mantzouki, C.; Bliatka, D.; Iliadou, P.K.; Margeli, A.; Papassotiriou, I.; Mastorakos, G.; Kousta, E.; Goulis, D.G. Serum Bisphenol A concentrations in men with idiopathic infertility. Food Chem. Toxicol. 2019, 125, 562-565. [CrossRef]

157. Ji, H.; Miao, M.; Liang, H.; Shi, H.; Ruan, D.; Li, Y.; Wang, J.; Yuan, W. Exposure of environmental Bisphenol A in relation to routine sperm parameters and sperm movement characteristics among fertile men. Sci. Rep. 2018, 8, 17548. [CrossRef] [PubMed]

158. Omran, G.A.; Gaber, H.D.; Mostafa, N.A.M.; Abdel-Gaber, R.M.; Salah, E.A. Potential hazards of bisphenol A exposure to semen quality and sperm DNA integrity among infertile men. Reprod. Toxicol. 2018, 81, 188-195. [CrossRef]

159. Radwan, M.; Wielgomas, B.; Dziewirska, E.; Radwan, P.; Kałużny, P.; Klimowska, A.; Hanke, W.; Jurewicz, J. Urinary Bisphenol A Levels and Male Fertility. Am. J. Men's Heal. 2018, 12, 2144-2151. [CrossRef]

160. Mok-Lin, E.; Ehrlich, S.; Williams, P.L.; Petrozza, J.; Wright, D.L.; Calafat, A.M.; Ye, X.; Hauser, R. Urinary bisphenol A concentrations and ovarian response among women undergoing IVF. Int. J. Androl. 2009, 33, 385-393. [CrossRef]

161. Lee, S.H.; Kang, S.M.; Choi, M.H.; Lee, J.; Park, M.J.; Kim, S.H.; Lee, W.-Y.; Hong, J.; Chung, B.C. Changes in steroid metabolism among girls with precocious puberty may not be associated with urinary levels of bisphenol A. Reprod. Toxicol. 2014, 44, 1-6. [CrossRef]

162. Wang, B.; Zhou, W.; Zhu, W.; Chen, L.; Wang, W.; Tian, Y.; Shen, L.; Zhang, J. The Shanghai Birth Cohort Study Associations of female exposure to bisphenol A with fecundability: Evidence from a preconception cohort study. Environ. Int. 2018, 117, 139-145. [CrossRef]

163. Lathi, R.B.; Liebert, C.; Brookfield, K.F.; Taylor, J.A.; Saal, F.S.V.; Fujimoto, V.Y.; Baker, V.L. Conjugated bisphenol A in maternal serum in relation to miscarriage risk. Fertil. Steril. 2014, 102, 123-128. [CrossRef]

164. Sugiura-Ogasawara, M.; Ozaki, Y.; Sonta, S.-I.; Makino, T.; Suzumori, K. Exposure to bisphenol A is associated with recurrent miscarriage. Hum. Reprod. 2005, 20, 2325-2329. [CrossRef] [PubMed]

165. Veiga-Lopez, A.; Kannan, K.; Liao, C.; Ye, W.; Domino, S.E.; Padmanabhan, V. Gender-Specific Effects on Gestational Length and Birth Weight by Early Pregnancy BPA Exposure. J. Clin. Endocrinol. Metab. 2015, 100, E1394-E1403. [CrossRef] [PubMed]

166. Pinney, S.E.; Mesaros, C.A.; Snyder, N.W.; Busch, C.M.; Xiao, R.; Aijaz, S.; Ijaz, N.; Blair, I.A.; Manson, J.M. Second trimester amniotic fluid bisphenol A concentration is associated with decreased birth weight in term infants. Reprod. Toxicol. 2016, 67, 1-9. [CrossRef] [PubMed]

167. Philips, E.M.; Santos, S.; Steegers, E.A.; Asimakopoulos, A.G.; Kannan, K.; Trasande, L.; Jaddoe, V.W. Maternal bisphenol and phthalate urine concentrations and weight gain during pregnancy. Environ. Int. 2019, 135, 105342. [CrossRef] [PubMed] 
168. Huo, W.; Xia, W.; Wan, Y.; Zhang, B.; Zhou, A.; Zhang, Y.; Huang, K.; Zhu, Y.; Wu, C.; Peng, Y.; et al. Maternal urinary bisphenol A levels and infant low birth weight: A nested case-control study of the Health Baby Cohort in China. Environ. Int. 2015, 85, 96-103. [CrossRef] [PubMed]

169. Müller, J.E.; Meyer, N.; Santamaria, C.G.; Schumacher, A.; Luque, E.H.; Zenclussen, M.L.; Rodriguez, H.A.; Zenclussen, A. Bisphenol A exposure during early pregnancy impairs uterine spiral artery remodeling and provokes intrauterine growth restriction in mice. Sci. Rep. 2018, 8, 9196. [CrossRef]

170. Konieczna, A.; Rachoń, D.; Owczarek, K.; Kubica, P.; Kowalewska, A.; Kudłak, B.; Wasik, A.; Namiesnik, J. Serum bisphenol A concentrations correlate with serum testosterone levels in women with polycystic ovary syndrome. Reprod. Toxicol. 2018, 82, 32-37. [CrossRef]

171. Shen, Y.; Zheng, Y.; Jiang, J.; Liu, Y.; Luo, X.; Shen, Z.; Chen, X.; Wang, Y.; Dai, Y.; Zhao, J.; et al. Higher Urinary Bisphenol A Concentration Is Associated with Unexplained Recurrent Miscarriage Risk: Evidence from a Case-Control Study in Eastern China. PLoS ONE 2015, 10, e0127886. [CrossRef]

172. Shi, M.; Sekulovski, N.; MacLean, J.A.; Hayashi, K. Effects of bisphenol A analogues on reproductive functions in mice. Reprod. Toxicol. 2017, 73, 280-291. [CrossRef]

173. Bergé, A.; Cladière, M.; Gasperi, J.; Coursimault, A.; Tassin, B.; Moilleron, R. Meta-analysis of environmental contamination by phthalates. Environ. Sci. Pollut. Res. 2013, 20, 8057-8076. [CrossRef]

174. Lyche, J.L. Reproductive and Developmental Toxicology, 2nd ed.; Academic Press: Cambridge, MA, USA, 2017; Chapter 44-Phthalates; pp. 829-856.

175. Loraine, G.A.; Pettigrove, M.E. Seasonal Variations in Concentrations of Pharmaceuticals and Personal Care Products in Drinking Water and Reclaimed Wastewater in Southern California. Environ. Sci. Technol. 2006, 40, 687-695. [CrossRef] [PubMed]

176. Liu, X.; Shi, J.; Bo, T.; Li, H.; Crittenden, J.C. Occurrence and risk assessment of selected phthalates in drinking water from waterworks in China. Environ. Sci. Pollut. Res. 2015, 22, 10690-10698. [CrossRef] [PubMed]

177. Chen, H.; Mao, W.; Shen, Y.; Feng, W.; Mao, G.; Zhao, T.; Yang, L.; Yang, L.; Meng, C.; Li, Y.; et al. Distribution, source, and environmental risk assessment of phthalate esters (PAEs) in water, suspended particulate matter, and sediment of a typical Yangtze River Delta City, China. Environ. Sci. Pollut. Res. 2019, 26, 24609-24619. [CrossRef] [PubMed]

178. Ding, M.; Kang, Q.; Zhang, S.; Zhao, F.; Mu, D.; Zhang, H.; Yang, M.; Hu, J. Contribution of phthalates and phthalate monoesters from drinking water to daily intakes for the general population. Chemosphere 2019, 229, 125-131. [CrossRef]

179. Xu, X.; Zhou, G.; Lei, K.; Leblanc, G.; An, L. Phthalate Esters and Their Potential Risk in PET Bottled Water Stored under Common Conditions. Int. J. Environ. Res. Public Heal. 2019, 17, 141. [CrossRef]

180. Amiridou, D.; Voutsa, D. Alkylphenols and phthalates in bottled waters. J. Hazard. Mater. 2011, 185, $281-286$. [CrossRef]

181. Santana, J.; Giraudi, C.; Marengo, E.; Robotti, E.; Pires, S.; Nunes, I.; Gaspar, E.M. Preliminary toxicological assessment of phthalate esters from drinking water consumed in Portugal. Environ. Sci. Pollut. Res. 2013, 21, 1380-1390. [CrossRef]

182. Yuan, B.; Wu, W.; Chen, M.; Gu, H.; Tang, Q.; Guo, D.; Chen, T.; Chen, Y.; Lu, C.; Song, L.; et al. From the Cover: Metabolomics Reveals a Role of Betaine in Prenatal DBP Exposure-Induced Epigenetic Transgenerational Failure of Spermatogenesis in Rats. Toxicol. Sci. 2017, 158, 356-366. [CrossRef]

183. Doyle, T.J.; Bowman, J.L.; Windell, V.L.; McLean, D.J.; Kim, K.H. Transgenerational effects of di-(2-ethylhexyl) phthalate on testicular germ cell associations and spermatogonial stem cells in mice. Boil. Reprod. 2013, 88, 112. [CrossRef]

184. Agarwal, D.K.; Lawrence, W.H.; Turner, J.E.; Autian, J. Effects of parenteral di-(2-ethylhexyl)phthalate (DEHP) on gonadal biochemistry, pathology, and reproductive performance of mice. J. Toxicol. Environ. Heal. Part A 1989, 26, 39-59. [CrossRef]

185. Moyer, B.; Hixon, M.L. Reproductive effects in F1 adult females exposed in utero to moderate to high doses of mono-2-ethylhexylphthalate (MEHP). Reprod. Toxicol. 2012, 34, 43-50. [CrossRef] [PubMed]

186. Pocar, P.; Fiandanese, N.; Berrini, A.; Secchi, C.; Borromeo, V. Maternal exposure to di(2-ethylhexyl)phthalate (DEHP) promotes the transgenerational inheritance of adult-onset reproductive dysfunctions through the female germline in mice. Toxicol. Appl. Pharmacol. 2017, 322, 113-121. [CrossRef] [PubMed] 
187. Meltzer, D.; Martinez-Arguelles, D.B.; Campioli, E.; Lee, S.; Papadopoulos, V. In utero exposure to the endocrine disruptor di(2-ethylhexyl) phthalate targets ovarian theca cells and steroidogenesis in the adult female rat. Reprod. Toxicol. 2015, 51, 47-56. [CrossRef] [PubMed]

188. Rattan, S.; Brehm, E.; Gao, L.; Flaws, J.A. Di(2-Ethylhexyl) Phthalate Exposure During Prenatal Development Causes Adverse Transgenerational Effects on Female Fertility in Mice. Toxicol. Sci. 2018, 163, 420-429. [CrossRef] [PubMed]

189. Lai, F.-N.; Liu, J.-C.; Li, L.; Ma, J.; Liu, X.-L.; Liu, Y.-P.; Zhang, X.-F.; Chen, H.; De Felici, M.; Dyce, P.; et al. Di (2-ethylhexyl) phthalate impairs steroidogenesis in ovarian follicular cells of prepuberal mice. Arch. Toxicol. 2016, 91, 1279-1292. [CrossRef] [PubMed]

190. Bornehag, C.-G.; Carlstedt, F.; Jönsson, B.; Lindh, C.H.; Jensen, M.B.; Bodin, A.; Jonsson, C.; Janson, S.; Swan, S. Prenatal Phthalate Exposures and Anogenital Distance in Swedish Boys. Environ. Heal. Perspect. 2014, 123, 101-107. [CrossRef]

191. Swan, S.; Sathyanarayana, S.; Barrett, E.S.; Janssen, S.; Liu, F.; Nguyen, R.H.N.; Redmon, J.B.; the TIDES Study Team; Scher, E.; Stasenko, M.; et al. First trimester phthalate exposure and anogenital distance in newborns. Hum. Reprod. 2015, 30, 963-972. [CrossRef]

192. Bloom, M.S.; Whitcomb, B.; Chen, Z.; Ye, A.; Kannan, K.; Louis, G.B. Associations between urinary phthalate concentrations and semen quality parameters in a general population. Hum. Reprod. 2015, 30, 2645-2657. [CrossRef]

193. Specht, I.O.; Toft, G.; Hougaard, K.S.; Lindh, C.H.; Lenters, V.; Jönsson, B.; Heederik, D.J.J.; Giwercman, A.; Bonde, J.P.E. Associations between serum phthalates and biomarkers of reproductive function in 589 adult men. Environ. Int. 2014, 66, 146-156. [CrossRef]

194. Axelsson, J.; Rylander, L.; Rignell-Hydbom, A.; Lindh, C.H.; Jönsson, B.A.; Giwercman, A. Prenatal phthalate exposure and reproductive function in young men. Environ. Res. 2015, 138, 264-270. [CrossRef]

195. Jurewicz, J.; Radwan, M.; Sobala, W.; Ligocka, D.; Radwan, P.; Bochenek, M.; Hawuła, W.; Jakubowski, L.; Hanke, W. Human urinary phthalate metabolites level and main semen parameters, sperm chromatin structure, sperm aneuploidy and reproductive hormones. Reprod. Toxicol. 2013, 42, 232-241. [CrossRef]

196. Pan, Y.; Jing, J.; Dong, F.; Yao, Q.; Zhang, W.; Zhang, H.; Yao, B.; Dai, J. Association between phthalate metabolites and biomarkers of reproductive function in 1066 Chinese men of reproductive age. J. Hazard. Mater. 2015, 300, 729-736. [CrossRef] [PubMed]

197. Hauser, R.; Meeker, J.D.; Duty, S.; Silva, M.J.; Calafat, A.M. Altered Semen Quality in Relation to Urinary Concentrations of Phthalate Monoester and Oxidative Metabolites. Epidemiology 2006, 17, 682-691. [CrossRef] [PubMed]

198. Thurston, S.W.; Mendiola, J.; Bellamy, A.R.; Levine, H.; Wang, C.; Sparks, A.; Redmon, J.B.; Drobnis, E.Z.; Swan, S.H. Phthalate exposure and semen quality in fertile US men. Andrologia 2015, 4, 632-638. [CrossRef] [PubMed]

199. Chang, W.-H.; Li, S.-S.; Wu, M.-H.; Pan, H.-A.; Lee, C.-C. Phthalates might interfere with testicular function by reducing testosterone and insulin-like factor 3 levels. Hum. Reprod. 2015, 30, 2658-2670. [CrossRef] [PubMed]

200. Watkins, D.J.; Téllez-Rojo, M.M.; Ferguson, K.K.; Lee, J.M.; Solano-González, M.; Blank-Goldenberg, C.; Peterson, K.E.; Meeker, J.D. In utero and peripubertal exposure to phthalates and BPA in relation to female sexual maturation. Environ. Res. 2014, 134, 233-241. [CrossRef]

201. Su, P.-H.; Chang, C.-K.; Lin, C.-Y.; Chen, H.-Y.; Liao, P.-C.; Hsiung, C.A.; Chiang, H.-C.; Wang, S.-L. Prenatal exposure to phthalate ester and pubertal development in a birth cohort in central Taiwan: A 12-year follow-up study. Environ. Res. 2015, 136, 324-330. [CrossRef]

202. Ziv-Gal, A.; Gallicchio, L.; Chiang, C.; Ther, S.N.; Miller, S.R.; Zacur, H.A.; Dills, R.L.; Flaws, J.A. Phthalate metabolite levels and menopausal hot flashes in midlife women. Reprod. Toxicol. 2016, 60, 76-81. [CrossRef]

203. Kaul, A.F.; Souney, P.F.; Osathanondh, R. A Review of Possible Toxicity of DI-2-Ethylhexylphthalate (DEHP) in Plastic Intravenous Containers: Effects on Reproduction. Drug Intell. Clin. Pharm. 1982, 16, 689-692. [CrossRef]

204. Hannon, P.R.; Peretz, J.; Flaws, J.A. Daily Exposure to Di(2-ethylhexyl) Phthalate Alters Estrous Cyclicity and Accelerates Primordial Follicle Recruitment Potentially Via Dysregulation of the Phosphatidylinositol 3-Kinase Signaling Pathway in Adult Mice1. Boil. Reprod. 2014, 90, 136. [CrossRef] 
205. Barakat, R.; Lin, P.-C.; Park, C.J.; Best-Popescu, C.; Bakry, H.H.; E Abosalem, M.; Abdelaleem, N.M.; Flaws, J.A.; Ko, C.; Bakery, H.H.; et al. Prenatal Exposure to DEHP Induces Neuronal Degeneration and Neurobehavioral Abnormalities in Adult Male Mice. Toxicol. Sci. 2018, 164, 439-452. [CrossRef] [PubMed]

206. Zhang, S.; Mo, J.; Wang, Y.; Ni, C.; Li, X.; Zhu, Q.; Ge, R.-S. Endocrine disruptors of inhibiting testicular 3 $\beta$-hydroxysteroid dehydrogenase. Chem. Interactions 2019, 303, 90-97. [CrossRef] [PubMed]

207. Swan, S. Environmental phthalate exposure in relation to reproductive outcomes and other health endpoints in humans. Environ. Res. 2008, 108, 177-184. [CrossRef] [PubMed]

208. Meeker, J.D.; Ferguson, K.K. Urinary phthalate metabolites are associated with decreased serum testosterone in men, women, and children from NHANES 2011-2012. J. Clin. Endocrinol. Metab. 2014, 99, 4346-4352. [CrossRef] [PubMed]

209. Wang, Y.-X.; Zeng, Q.; Sun, Y.; Yang, P.; Wang, P.; Li, J.; Huang, Z.; You, L.; Huang, Y.-H.; Wang, C.; et al. Semen phthalate metabolites, semen quality parameters and serum reproductive hormones: A cross-sectional study in China. Environ. Pollut. 2016, 211, 173-182. [CrossRef]

210. You, L.; Wang, Y.-X.; Zeng, Q.; Li, M.; Huang, Y.-H.; Hu, Y.; Cao, W.-C.; Liu, A.-L.; Lu, W.-Q. Semen Phthalate Metabolites, Spermatozoa Apoptosis, and DNA Damage: A Cross-Sectional Study in China. Environ. Sci. Technol. 2015, 49, 3805-3812. [CrossRef]

211. Huang, P.-C.; Tsai, C.-H.; Liang, W.-Y.; Li, S.-S.; Pan, W.-H.; Chiang, H.-C. Age and Gender Differences in Urinary Levels of Eleven Phthalate Metabolites in General Taiwanese Population after a DEHP Episode. PLoS ONE 2015, 10, e0133782. [CrossRef]

212. Heudorf, U.; Mersch-Sundermann, V.; Angerer, J. Phthalates: Toxicology and exposure. Int. J. Hyg. Environ. Heal. 2007, 210, 623-634. [CrossRef]

213. Gladen, B.C. Variability of lipid hydroperoxides in pregnant and nonpregnant women. Reprod. Toxicol. 1999, 13, 41-44. [CrossRef]

214. Jansen, E.H.J.M.; van den Ham, W.A.; de Fluiter, P.; Laan, C.A.; van Leeuwen, F.X.R. Toxicological investigation of Di (ethyl-hexyl) phthalate in rats. The determination of doses-without-effect for various enzyme parameters. RIVM Rapport 618902004. 1992. Available online: https://rivm.openrepository.com/handle/10029/262347 (accessed on 10 January 2020).

215. NPTN. Pesticides in drinking water. 2000. Available online: http://npic.orst.edu/factsheets/drinkingwater. pdf.Accessedon10ctober2019 (accessed on 10 January 2020).

216. USEPA. Results of the Lake Michigan Mass Balance Study: Atrazine Data Report; report number EPA EPA 905R-01-010; EPA: Washington, DC, USA, 2001.

217. Explained, E.S. Archive:Agri-environmental indicator-pesticide pollution of water. 2018. Available online: https://ec.europa.eu/eurostat/statistics-explained/index.php/Archive:Agri-environmental_ indicator_-_pesticide_pollution_of_water (accessed on 10 January 2020).

218. Barbash, J.E.; Thelin, G.P.; Kolpin, D.W.; Gilliom, R.J. Major Herbicides in Ground Water: Results from the National Water-Quality Assessment. J. Environ. Qual. 2001, 30, 831-845. [CrossRef]

219. Wood, T.J.; Goulson, D. The environmental risks of neonicotinoid pesticides: A review of the evidence post 2013. Environ. Sci. Pollut. Res. 2017, 24, 17285-17325. [CrossRef] [PubMed]

220. Morrissey, C.A.; Mineau, P.; Devries, J.H.; Sanchez-Bayo, F.; Liess, M.; Cavallaro, M.C.; Liber, K. Neonicotinoid contamination of global surface waters and associated risk to aquatic invertebrates: A review. Environ. Int. 2015, 74, 291-303. [CrossRef] [PubMed]

221. Sur, R.; Stork, A. Uptake, translocation and metabolism ofimidacloprid in plants. Bull. Insectol. 2003, 56, 35-40.

222. Di, S.; Diao, J.; Wang, X.; Qi, P.; Wang, Z.; Xu, H.; Zhang, H.; Wang, X.; Han, J. Bioaccumulation of dichlorodiphenyltrichloroethanes (DDTs) in carp in a water/sediment microcosm: Important role of sediment particulate matter and bioturbation. Environ. Sci. Pollut. Res. 2019, 26, 9500-9507. [CrossRef] [PubMed]

223. Tadevosyan, N.S.; Poghosyan, S.B.; Khachatryan, B.G.; Muradyan, S.A.; Guloyan, H.A.; Tshantshapanyan, A.N.; Hutchings, N.J.; Tadevosyan, A.E. Residues of xenobiotics in the environment and phytotoxic activity in Armenia. J. Environ. Sci. Heal. Part A 2019, 54, 1011-1018. [CrossRef]

224. Di, S.; Liu, R.; Tian, Z.; Cheng, C.; Chen, L.; Zhang, W.; Zhou, Z.; Diao, J. Assessment of tissue-specific accumulation, elimination and toxic effects of dichlorodiphenyltrichloroethanes (DDTs) in carp through aquatic food web. Sci. Rep. 2017, 7, 2288. [CrossRef] 
225. Sun, X.; Liu, F.; Shan, R.; Fan, Y. Spatiotemporal distributions of $\mathrm{Cu}, \mathrm{Zn}$, metribuzin, atrazine, and their transformation products in the surface water of a small plain stream in eastern China. Environ. Monit. Assess. 2019, 191, 433. [CrossRef]

226. Malhat, F.; Nasr, I. Organophosphorus Pesticides Residues in Fish Samples from the River Nile Tributaries in Egypt. Bull. Environ. Contam. Toxicol. 2011, 87, 689-692. [CrossRef]

227. Plimmer, J.R. Fate of Pesticides and Chemicals in the Environment-Dissipation of Pesticides in the Environment. Sci. Total. Environ. 1992, 1-6.

228. Zabik, J.M.; Seiber, J.N. Atmospheric Transport of Organophosphate Pesticides from California's Central Valley to the Sierra Nevada Mountains. J. Environ. Qual. 1993, 22, 80-90. [CrossRef]

229. Cowart, R.P.; Bonner, F.L.; Epps, E.A. Rate of hydrolysis of seven organophosphate pesticides. Bull. Environ. Contam. Toxicol. 1971, 6, 231-234. [CrossRef] [PubMed]

230. Ragnarsdottir, K.V. Environmental fate and toxicology of organophosphate pesticides. J. Geol. Soc. 2000, 157, 859-876. [CrossRef]

231. Mekonen, S.; Argaw, R.; Simanesew, A.; Houbraken, M.; Senaeve, D.; Ambelu, A.; Spanoghe, P. Pesticide residues in drinking water and associated risk to consumers in Ethiopia. Chemosphere 2016, 162, 252-260. [CrossRef] [PubMed]

232. Papadakis, E.-N.; Vryzas, Z.; Kotopoulou, A.; Kintzikoglou, K.; Makris, K.C.; Papadopoulou-Mourkidou, E. A pesticide monitoring survey in rivers and lakes of northern Greece and its human and ecotoxicological risk assessment. Ecotoxicol. Environ. Saf. 2015, 116, 1-9. [CrossRef] [PubMed]

233. Flores-García, M.E.; Molina-Morales, Y.; Balza-Quintero, A.; Benítez-Díaz, P.R.; Miranda-Contreras, L. [Pesticide residues in drinking water of an agricultural community in the state of Mérida, Venezuela]. Investigación Clínica 2011, 52, 295-311.

234. Wilson, J.D. Toxicological profile for malathion; Agency for Toxic Substances and Disease Registry: Atlanta, GA, USA, 2003.

235. Fingler, S.; Mendaš, G.; Dvoršćak, M.; Stipičević, S.; Vasilić, Ž.; Drevenkar, V. Herbicide micropollutants in surface, ground and drinking waters within and near the area of Zagreb, Croatia. Environ. Sci. Pollut. Res. 2016, 24, 11017-11030. [CrossRef]

236. Li, H.; Feng, Y.; Li, X.; Zeng, N. Analytical Confirmation of Various Herbicides in Drinking Water Resources in Sugarcane Production Regions of Guangxi, China. Bull. Environ. Contam. Toxicol. 2018, 100, 815-820. [CrossRef]

237. Loos, R.; Wollgast, J.; Huber, T.; Hanke, G. Polar herbicides, pharmaceutical products, perfluorooctanesulfonate (PFOS), perfluorooctanoate (PFOA), and nonylphenol and its carboxylates and ethoxylates in surface and tap waters around Lake Maggiore in Northern Italy. Anal. Bioanal. Chem. 2007, 387, 1469-1478. [CrossRef]

238. Song, Y.; Jia, Z.C.; Chen, J.Y.; Hu, J.X.; Zhang, L. Toxic effects of atrazine on reproductive system of male rats. Biomed. Environ. Sci. 2014, 27, 281-288.

239. Laws, S.C.; Ferrell, J.M.; Stoker, T.; Schmid, J.; Cooper, R.L. The effects of atrazine on female wistar rats: An evaluation of the protocol for assessing pubertal development and thyroid function. Toxicol. Sci. 2000, 58, 366-376. [CrossRef]

240. Cooper, R.L.; Laws, S.C.; Das, P.C.; Narotsky, M.G.; Goldman, J.M.; Tyrey, E.L.; Stoker, T. Atrazine and reproductive function: Mode and mechanism of action studies. Birth Defects Res. Part B: Dev. Reprod. Toxicol. 2007, 80, 98-112. [CrossRef] [PubMed]

241. Park, S.; Kim, S.; Jin, H.; Lee, K.; Bae, J. Impaired development of female mouse offspring maternally exposed to simazine. Environ. Toxicol. Pharmacol. 2014, 38, 845-851. [CrossRef] [PubMed]

242. Zorrilla, L.M.; Gibson, E.K.; Stoker, T. The effects of simazine, a chlorotriazine herbicide, on pubertal development in the female Wistar rat. Reprod. Toxicol. 2010, 29, 393-400. [CrossRef] [PubMed]

243. Park, H.-O.; Bae, J. Disturbed Relaxin Signaling Pathway and Testicular Dysfunction in Mouse Offspring upon Maternal Exposure to Simazine. PLoS ONE 2012, 7, e44856. [CrossRef] [PubMed]

244. Mathias, F.T.; Romano, R.M.; Sleiman, H.K.; De Oliveira, C.A.; Romano, M.A. Herbicide Metolachlor Causes Changes in Reproductive Endocrinology of Male Wistar Rats. ISRN Toxicol. 2012, 2012, 1-7. [CrossRef] [PubMed]

245. Song, X.; Zhang, F.; Chen, D.; Bian, Q.; Zhang, H.; Liu, X.; Zhu, B. Study on systemic and reproductive toxicity of acetochlor in male mice. Toxicol. Res. 2019, 8, 77-89. [CrossRef] 
246. Rollerová, E.; Wsolova, L.; Urbančíková, M. Neonatal exposure to herbicide acetochlor alters pubertal development in female wistar rats. Toxicol. Mech. Methods 2011, 21, 406-417. [CrossRef]

247. Geng, X.; Bo, C.; Han, G.; Shao, H. Effects of malathion on testicular spermatogenic function in rats. Zhonghua lao dong wei sheng zhi ye bing za zhi/Zhonghua laodong weisheng zhiyebing zazhi/Chin. J. Ind. Hyg. Occup. Dis. 2015, 33, 180-185.

248. Babazadeh, M.; Najafi, G. Effect of chlorpyrifos on sperm characteristics and testicular tissue changes in adult male rats. Veter-Res. Forum Int. Q. J. 2017, 8, 319-326.

249. Sai, L.; Li, X.; Liu, Y.; Guo, Q.; Xie, L.; Yu, G.; Bo, C.; Zhang, Z.; Li, L. Effects of chlorpyrifos on reproductive toxicology of male rats. Environ. Toxicol. 2013, 29, 1083-1088. [CrossRef]

250. Bal, R.; Nazıroğlu, M.; Turk, G.; Yilmaz, O.; Kuloglu, T.; Etem, E.; Baydas, G. Insecticide imidacloprid induces morphological and DNA damage through oxidative toxicity on the reproductive organs of developing male rats. Cell Biochem. Funct. 2012, 30, 492-499. [CrossRef] [PubMed]

251. Kapoor, U.; Srivastava, M.; Srivastava, L. Toxicological impact of technical imidacloprid on ovarian morphology, hormones and antioxidant enzymes in female rats. Food Chem. Toxicol. 2011, 49, 3086-3089. [CrossRef] [PubMed]

252. Bal, R.; Turk, G.; Tuzcu, M.; Yilmaz, O.; Kuloglu, T.; Baydas, G.; Nazıroğlu, M.; Yener, Z.; Etem, E.; Tuzcu, Z. Effects of the neonicotinoid insecticide, clothianidin, on the reproductive organ system in adult male rats. Drug Chem. Toxicol. 2013, 36, 421-429. [CrossRef] [PubMed]

253. Swan, S.; Kruse, R.; Liu, F.; Barr, D.B.; Drobnis, E.Z.; Redmon, J.B.; Wang, C.; Brazil, C.; Overstreet, J.W. Study for Future Families Research Group Semen quality in relation to biomarkers of pesticide exposure. Environ. Heal. Perspect. 2003, 111, 1478-1484. [CrossRef] [PubMed]

254. Munger, R.; Isacson, P.; Hu, S.; Burns, T.; Hanson, J.; Lynch, C.F.; Cherryholmes, K.; Van Dorpe, P.; Hausler, W.J. Intrauterine growth retardation in Iowa communities with herbicide-contaminated drinking water supplies. Environ. Heal. Perspect. 1997, 105, 308-314. [CrossRef] [PubMed]

255. Wirbisky, S.E.; Freeman, J. Atrazine Exposure and Reproductive Dysfunction through the Hypothalamus-Pituitary-Gonadal (HPG) Axis. Toxics 2015, 3, 414-450. [CrossRef]

256. Forgacs, A.L.; D'Souza, M.L.; Huhtaniemi, I.T.; Rahman, N.A.; Zacharewski, T.R. Triazine Herbicides and Their Chlorometabolites Alter Steroidogenesis in BLTK1 Murine Leydig Cells. Toxicol. Sci. 2013, 134, $155-167$. [CrossRef]

257. Powell, K.W.; Cope, W.G.; LePrevost, C.; Augspurger, T.; McCarthy, A.M.; Shea, D. A Retrospective Analysis of Agricultural Herbicides in Surface Water Reveals Risk Plausibility for Declines in Submerged Aquatic Vegetation. Toxics 2017, 5, 21. [CrossRef]

258. Glinski, D.A.; Purucker, S.T.; Van Meter, R.J.; Black, M.C.; Henderson, W.M. Analysis of pesticides in surface water, stemflow, and throughfall in an agricultural area in South Georgia, USA. Chemosphere 2018, 209, 496-507. [CrossRef]

259. Focazio, M.J.; Kolpin, D.W.; Barnes, K.; Furlong, E.T.; Meyer, M.T.; Zaugg, S.D.; Barber, L.B.; Thurman, E.M. A national reconnaissance for pharmaceuticals and other organic wastewater contaminants in the United States-II) Untreated drinking water sources. Sci. Total. Environ. 2008, 402, 201-216. [CrossRef]

260. Herrero-Hernández, E.; Rodríguez-Cruz, M.S.; Juan, E.P.; Sánchez-González, S.; Andrades, M.S.; Sánchez-Martín, M.J. Seasonal distribution of herbicide and insecticide residues in the water resources of the vineyard region of La Rioja (Spain). Sci. Total. Environ. 2017, 609, 161-171. [CrossRef] [PubMed]

261. Yu, Z.Y.; Jin, F.; Li, H.Y.; An, W.; Yang, M. Residual levels of acetochlor in source water and drinking water of China's major cities. Huan jing ke xue= Huanjing kexue 2014, 35, 1694-1697. [PubMed]

262. Wan, Y.; Wang, Y.; Xia, W.; He, Z.; Xu, S.-Q. Neonicotinoids in raw, finished, and tap water from Wuhan, Central China: Assessment of human exposure potential. Sci. Total. Environ. 2019, 675, 513-519. [CrossRef] [PubMed]

263. Klarich, K.L.; Pflug, N.C.; Dewald, E.M.; Hladik, M.L.; Kolpin, D.W.; Cwiertny, D.M.; Lefevre, G.H. Occurrence of Neonicotinoid Insecticides in Finished Drinking Water and Fate during Drinking Water Treatment. Environ. Sci. Technol. Lett. 2017, 4, 168-173. [CrossRef]

264. Aris, A.Z.; Shamsuddin, A.S.; Praveena, S.M. Occurrence of $17 \alpha$-ethynylestradiol (EE2) in the environment and effect on exposed biota: A review. Environ. Int. 2014, 69, 104-119. [CrossRef] [PubMed]

265. Adeel, M.; Song, X.; Wang, Y.; Francis, D.; Yuesuo, Y. Environmental impact of estrogens on human, animal and plant life: A critical review. Environ. Int. 2017, 99, 107-119. [CrossRef] 
266. Słomczyńska, M. Xenoestrogens: Mechanisms of action and some detection studies. Pol. J. Veter- Sci. 2008, 11, 263-269.

267. Barton, H.; Berbel-Filho, W.M.; Consuegra, S.; Francis, L.; Tizaoui, C.; Conlan, R.; Teixeira, S.R. Ultrasensitive environmental assessment of xeno-estrogens in water samples using label-free graphene immunosensors. Anal. Biochem. 2018, 548, 102-108. [CrossRef]

268. Nie, Q.; Xing, M.; Hu, J.; Hu, X.; Nie, S.; Xie, M.-Y. Metabolism and health effects of phyto-estrogens. Crit. Rev. Food Sci. Nutr. 2015, 57, 2432-2454. [CrossRef]

269. Arcand-Hoy, L.D.; Nimrod, A.C.; Benson, W.H.; Arcand-Hoy, A.C.N.L.D. Endocrine-Modulating Substances in the Environment: Estrogenic Effects of Pharmaceutical Products. Int. J. Toxicol. 1998, 17, 139-158. [CrossRef]

270. Biswas, S.; Shapiro, C.A.; Kranz, W.L.; Mader, T.L.; Shelton, D.P.; Snow, D.D.; Bartelt-Hunt, S.L.; Tarkalson, D.D.; Van Donk, S.J.; Zhang, T.C.; et al. Current knowledge on the environmental fate, potential impact, and management of growth-promoting steroids used in the US beef cattle industry. J. Soil Water Conserv. 2013, 68, 325-336. [CrossRef]

271. Wise, A.; O'Brien, K.; Woodruff, T. Are Oral Contraceptives a Significant Contributor to the Estrogenicity of Drinking Water? Environ. Sci. Technol. 2011, 45, 51-60. [CrossRef] [PubMed]

272. Caldwell, D.J.; Mastrocco, F.; Nowak, E.; Johnston, J.; Yekel, H.; Pfeiffer, D.; Hoyt, M.; DuPlessie, B.M.; Anderson, P.D. An Assessment of Potential Exposure and Risk from Estrogens in Drinking Water. Environ. Heal. Perspect. 2009, 118, 338-344. [CrossRef] [PubMed]

273. Czajka, C.P.; Londry, K. Anaerobic biotransformation of estrogens. Sci. Total. Environ. 2006, 367, $932-941$. [CrossRef]

274. Alvarez, D.; Shappell, N.; Billey, L.; Bermudez, D.; Wilson, V.S.; Kolpin, D.W.; Perkins, S.; Evans, N.; Foreman, W.; Gray, J.L.; et al. Bioassay of estrogenicity and chemical analyses of estrogens in streams across the United States associated with livestock operations. Water Res. 2013, 47, 3347-3363. [CrossRef]

275. Liu, X.; Shi, J.; Zhang, H.; Zhan, X.; Shen, G.; Hu, S. Estimating Estrogen Release and Load from Humans and Livestock in Shanghai, China. J. Environ. Qual. 2014, 43, 568-577. [CrossRef]

276. Hu, Y.; Yan, X.; Shen, Y.; Di, M.; Wang, J. Occurrence, behavior and risk assessment of estrogens in surface water and sediments from Hanjiang River, Central China. Ecotoxicology 2019, 28, 143-153. [CrossRef]

277. Esteban, S.; Gorga, M.; Petrovic, M.; González-Alonso, S.; Barceló, J.; Valcárcel, Y. Analysis and occurrence of endocrine-disrupting compounds and estrogenic activity in the surface waters of Central Spain. Sci. Total. Environ. 2014, 466, 939-951. [CrossRef]

278. A Kidd, K.; Blanchfield, P.; Mills, K.H.G.; Palace, V.P.; Evans, R.E.; Lazorchak, J.; Flick, R.W. Collapse of a fish population after exposure to a synthetic estrogen. Proc. Natl. Acad. Sci. USA 2007, 104, 8897-8901. [CrossRef]

279. Tetreault, G.R.; Bennett, C.J.; Shires, K.; Knight, B.; Servos, M.R.; McMaster, M.E. Intersex and reproductive impairment of wild fish exposed to multiple municipal wastewater discharges. Aquat. Toxicol. 2011, 104, 278-290. [CrossRef]

280. Jobling, S.; Nolan, M.; Tyler, C.R.; Brighty, G.; Sumpter, J.P. Widespread Sexual Disruption in Wild Fish. Environ. Sci. Technol. 1998, 32, 2498-2506. [CrossRef]

281. Vajda, A.; Barber, L.B.; Gray, J.L.; Lopez, E.M.; Bolden, A.M.; Schoenfuss, H.L.; Norris, D.O. Demasculinization of male fish by wastewater treatment plant effluent. Aquat. Toxicol. 2011, 103, 213-221. [CrossRef] [PubMed]

282. Bahamonde, P.; Munkittrick, K.R.; Martyniuk, C.J. Intersex in teleost fish: Are we distinguishing endocrine disruption from natural phenomena? Gen. Comp. Endocrinol. 2013, 192, 25-35. [CrossRef] [PubMed]

283. Huang, G.-Y.; Liu, Y.-S.; Chen, X.-W.; Liang, Y.-Q.; Liu, S.-S.; Yang, Y.-Y.; Hu, L.-X.; Shi, W.-J.; Tian, F.; Zhao, J.-L.; et al. Feminization and masculinization of western mosquitofish (Gambusia affinis) observed in rivers impacted by municipal wastewaters. Sci. Rep. 2016, 6, 20884. [CrossRef] [PubMed]

284. Hogan, N.S.; Duarte, P.; Wade, M.G.; Lean, D.R.; Trudeau, V.L. Estrogenic exposure affects metamorphosis and alters sex ratios in the northern leopard frog (Rana pipiens): Identifying critically vulnerable periods of development. Gen. Comp. Endocrinol. 2008, 156, 515-523. [CrossRef] [PubMed]

285. Kriszt, R.; Winkler, Z.; Polyák, Á.; Kuti, D.; Molnár, C.; Hrabovszky, E.; Kalló, I.; Szőke, Z.; Ferenczi, S.; Kovács, K.J. Xenoestrogens Ethinyl Estradiol and Zearalenone Cause Precocious Puberty in Female Rats via Central Kisspeptin Signaling. Endocrinology 2015, 156, 3996-4007. [CrossRef] [PubMed] 
286. Xia, Y.; Chen, M.; Zhu, P.; Lu, C.; Fu, G.; Zhou, X.; Chen, D.; Wang, H.; Hang, B.; Wang, S.; et al. Urinary phytoestrogen levels related to idiopathic male infertility in Chinese men. Environ. Int. 2013, 59, 161-167. [CrossRef]

287. Ibarluzea, J.M.; Fernandez, M.F.; Marina, L.S.; Olea-Serrano, M.F.; Rivas, A.; Aurrekoetxea, J.J.; Expósito, J.; Lorenzo, M.; Torné, P.; Villalobos, M.; et al. Breast Cancer Risk and the Combined Effect of Environmental Estrogens. Cancer Causes Control. 2004, 15, 591-600. [CrossRef] 